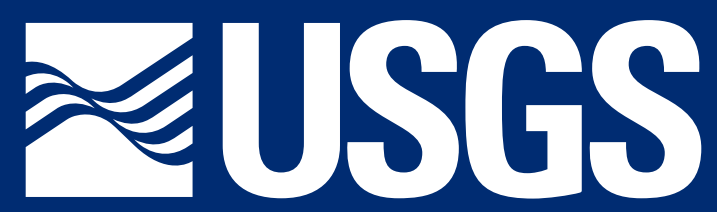

science for a changing world

\title{
Quality and Sources of Shallow Ground Water in Areas of Recent Residential Development in Salt Lake Valley, Salt Lake County, Utah
}

Water-Resources Investigations Report 03-4028

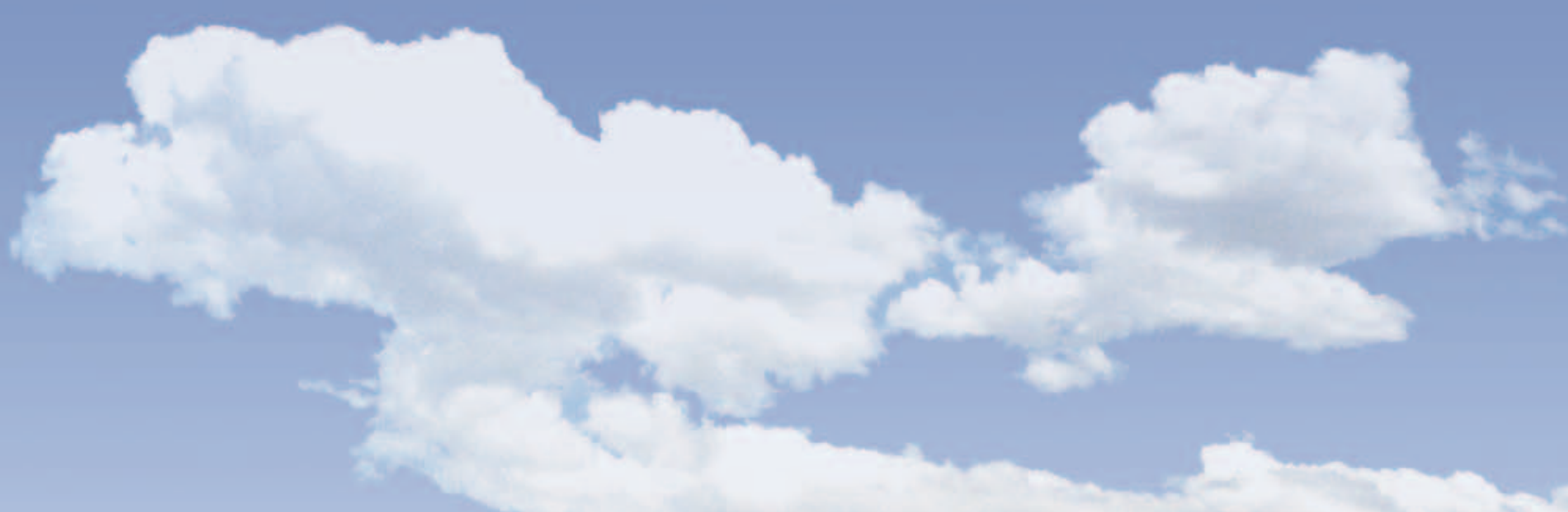

U.S. Department of the Interior

U.S. Geological Survey

National Water-Quality Assessment Program 


\section{Quality and Sources of Shallow Ground Water in Areas of Recent Residential Development in Salt Lake Valley, Salt Lake County, Utah}

By Susan A. Thiros

U.S. GEOLOGICAL SURVEY

Water-Resources Investigations Report 03-4028

NATIONAL WATER-QUALITY ASSESSMENT PROGRAM

Salt Lake City, Utah 


\title{
U.S. DEPARTMENT OF THE INTERIOR \\ GALE A. NORTON, Secretary
}

\author{
U.S. GEOLOGICAL SURVEY \\ Charles G. Groat, Director
}

Any use of trade, product, or firm names in this publication is for descriptive purposes only and does not imply endorsement by the U.S. Government.

For additional information write to:

\section{District Chief}

U.S. Geological Survey

2329 West Orton Circle

Salt Lake City, Utah 84119

http://ut.water.usgs.gov
Copies of this report can be purchased from:
U.S. Geological Survey
Branch of Information Services
Box 25286
Denver Federal Center
Denver, C0 80225-0286
1-888-ASK-USGS 


\section{FOREWORD}

The U.S. Geological Survey (USGS) is committed to serve the Nation with accurate and timely scientific information that helps enhance and protect the overall quality of life, and facilitates effective management of water, biological, energy, and mineral resources (http://www.usgs.gov/). Information on the quality of the Nation's water resources is of critical interest to the USGS because it is so integrally linked to the long-term availability of water that is clean and safe for drinking and recreation and that is suitable for industry, irrigation, and habitat for fish and wildlife. Escalating population growth and increasing demands for the multiple water uses make water availability, now measured in terms of quantity and quality, even more critical to the long-term sustainability of our communities and ecosystems.

The USGS implemented the National Water-Quality Assessment (NAWQA) program to support national, regional, and local information needs and decisions related to water-quality management and policy (http://water.usgs.gov/nawqa). Shaped by and coordinated with ongoing efforts of other Federal, State, and local agencies, the NAWQA program is designed to answer: What is the condition of our Nation's streams and ground water? How are the conditions changing over time? How do natural features and human activities affect the quality of streams and ground water, and where are those effects most pronounced? By combining information on water chemistry, physical characteristics, stream habitat, and aquatic life, the NAWQA program aims to provide sciencebased insights for current and emerging water issues and priorities. NAWQA results can contribute to informed decisions that result in practical and effective water-resource management and strategies that protect and restore water quality.

Since 1991, the NAWQA program has implemented interdisciplinary assessments in more than 50 of the Nation's most important river basins and aquifers, referred to as Study Units (http://water.usgs.gov/nawqa/ nawqamap.html). Collectively, these Study Units account for more than 60 percent of the overall water use and population served by public water supply, and are representative of the Nation's major hydrologic landscapes, priority ecological resources, and agricultural, urban, and natural sources of contamination.

Each assessment is guided by a nationally consistent study design and methods of sampling and analysis. The assessments thereby build local knowledge about water-quality issues and trends in a particular stream or aquifer while providing an understanding of how and why water quality varies regionally and nationally. The consistent, multi-scale approach helps to determine if certain types of water-quality issues are isolated or pervasive, and allows direct comparisons of how human activities and natural processes affect water quality and ecological health in the Nation's diverse geographic and environmental settings. Comprehensive assessments on pesticides, nutrients, volatile organic compounds, trace metals, and aquatic ecology are developed at the national scale through comparative analysis of the Study-Unit findings (http://water.usgs.gov/nawqa/natsyn.html).

The USGS places high value on the communication and dissemination of credible, timely, and relevant science so that the most recent and available knowledge about water resources can be applied in management and policy decisions. We hope this NAWQA publication will provide you the needed insights and information to meet your needs, and thereby foster increased awareness and involvement in the protection and restoration of our Nation's waters.

The NAWQA program recognizes that a national assessment by a single program cannot address all waterresource issues of interest. External coordination at all levels is critical for a fully integrated understanding of watersheds and for cost-effective management, regulation, and conservation of our Nation's water resources. The program, therefore, depends extensively on the advice, cooperation, and information from other Federal, State, interstate, Tribal, and local agencies, non-government organizations, industry, academia, and other stakeholder groups. The assistance and suggestions of all are greatly appreciated.

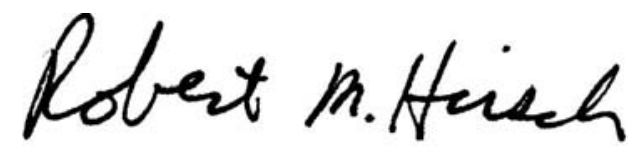

Robert M. Hirsch

Associate Director for Water 


\section{CONTENTS}

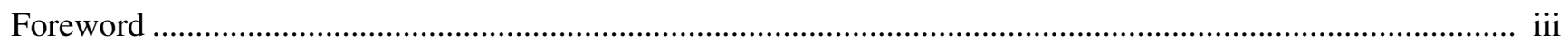

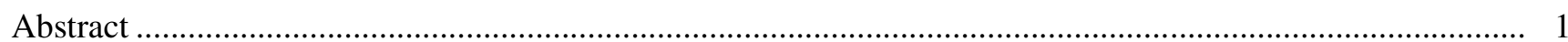

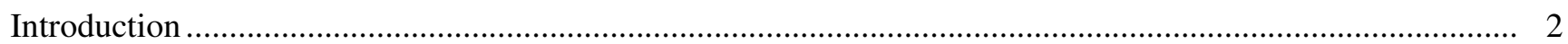

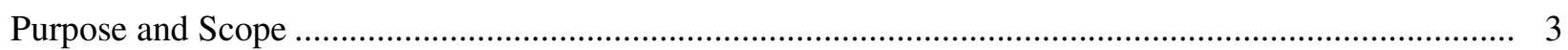

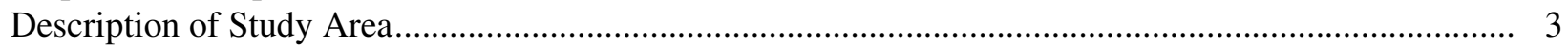

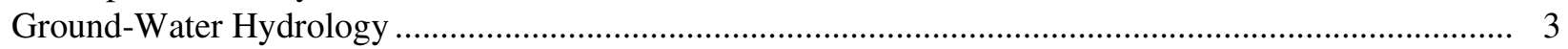

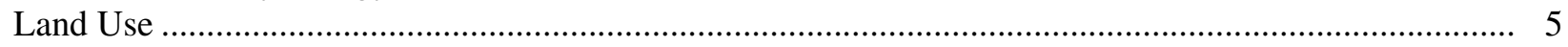

Acknowledgments

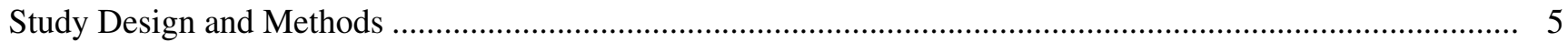

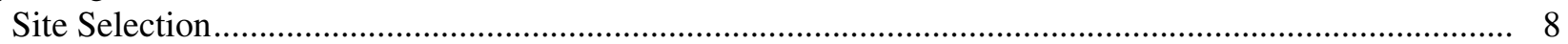

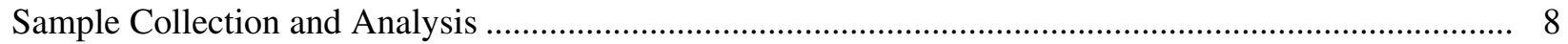

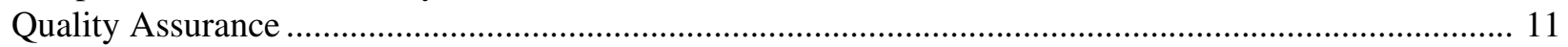

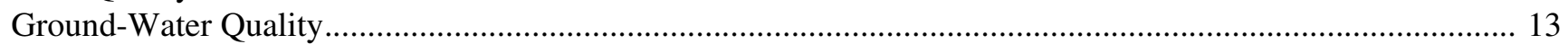

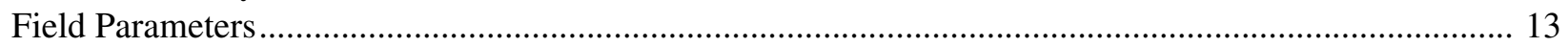

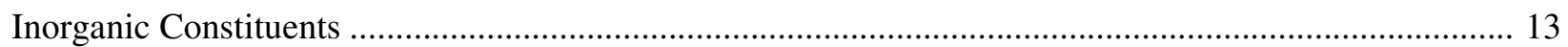

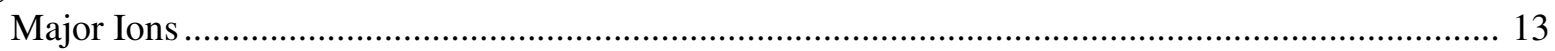

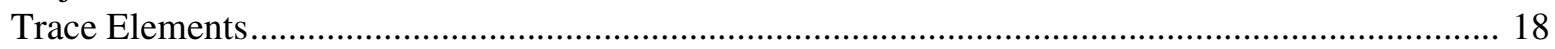

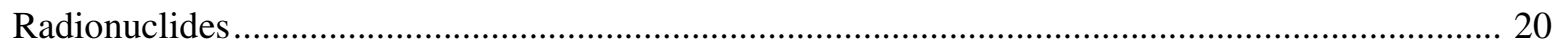

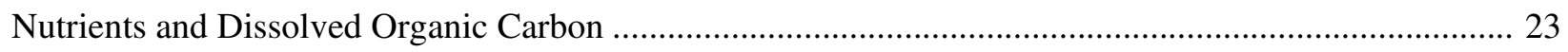

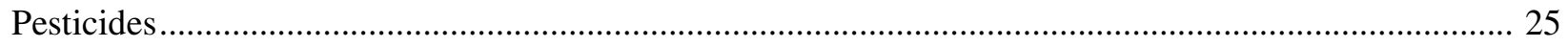

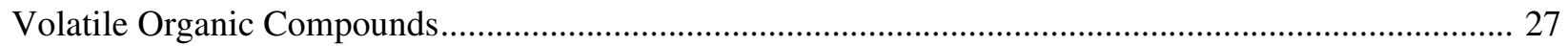

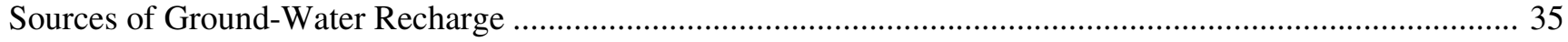

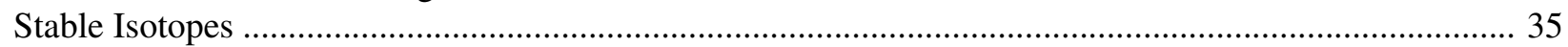

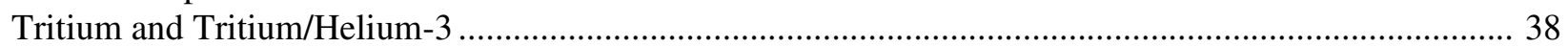

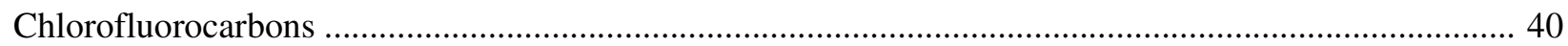

Effects of Shallow Ground-Water Quality on Deeper Ground-Water Quality .............................................. 41

Relation Between Ground-Water Quality and Land Use .................................................................. 42

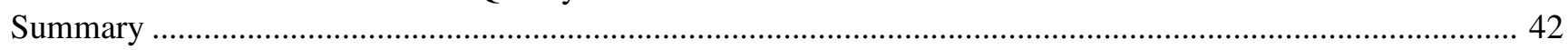

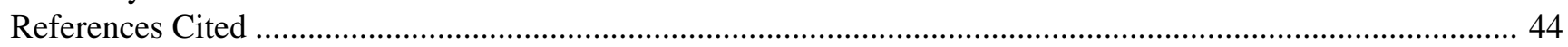

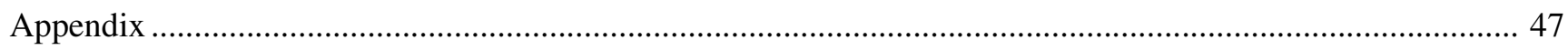




\section{FIGURES}

Figure 1 Map showing location and geographic features of Salt Lake Valley, Utah................................. 4

Figure 2. Generalized block diagram showing the basin-fill deposits and ground-water flow system in

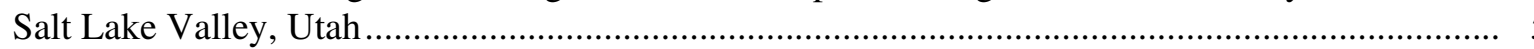

Figure 3. Map showing location of recharge and discharge areas and monitoring wells installed in areas of recent residential development, Salt Lake Valley, Utah ......................................................... 6

Figure 4. $\quad$ Map showing land use in Salt Lake Valley, Utah, 1994 ......................................................... 7

Figure 5. Graph showing percentage of land-use type mapped within a 1,640-foot radius of monitoring

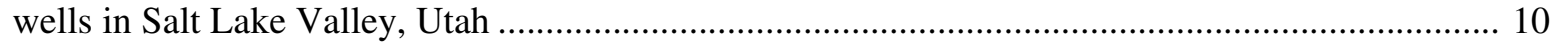

Figure 6. Map showing dissolved-solids concentration in water sampled from monitoring wells in areas of recent residential development, Salt Lake Valley, Utah ......................................................... 17

Figure 7. Diagrams showing major-ion composition of water sampled from monitoring wells in areas of recent residential development, Salt Lake Valley, Utah

Figure 8. Map showing arsenic concentration in water sampled from monitoring wells in areas of recent residential development, Salt Lake Valley, Utah.

Figure 9. Map showing radon concentration in water sampled from monitoring wells in areas of recent residential development, Salt Lake Valley, Utah.

Figure 10. Map showing nitrate concentration in water sampled from monitoring wells in areas of recent residential development, Salt Lake Valley, Utah.

Figure 11. Graph showing detection frequency of pesticides in water sampled from monitoring wells in areas of recent residential development, Salt Lake Valley, Utah ..... 25

Figure 12. Graph showing concentration of selected pesticides in water sampled from monitoring wells in areas of recent residential development, Salt Lake Valley, Utah ....

Figure 13. Map showing total concentration of atrazine and its degradation products in water sampled from monitoring wells in areas of recent residential development, Salt Lake Valley, Utah.....

Figure 14. Map showing prometon concentration in water sampled from monitoring wells in areas of

recent residential development, Salt Lake Valley, Utah 28 29

Figure 15. Graph showing detection frequency of volatile organic compounds in water sampled from monitoring wells in areas of recent residential development, Salt Lake Valley, Utah.....

Figure 16. Graph showing concentration of selected volatile organic compounds in water sampled from monitoring wells in areas of recent residential development, Salt Lake Valley, Utah......

Figure 17. Map showing chloroform concentration in water sampled from monitoring wells in areas of recent residential development, Salt Lake Valley, Utah

Figure 18. Map showing tetrachloroethylene (PCE) concentration in water sampled from monitoring wells in areas of recent residential development, Salt Lake Valley, Utah.....

Figure 19. Graph showing relation between delta deuterium and delta oxygen-18 for shallow groundwater and surface-water samples from Salt Lake Valley, Utah....

Figure 20. Graph showing relation between delta deuterium and delta oxygen-18 for water samples from selected wells and from Little Cottonwood Creek, Salt Lake Valley, Utah. 38

Figure 21. Graph showing tritium concentration in precipitation and in water sampled from monitoring wells in areas of recent residential development, Salt Lake Valley, Utah...... 


\section{TABLES}

Table 1. Description of 30 monitoring wells sampled in Salt Lake Valley, Utah, 1999

Table 2. Summary of field parameters, inorganic constituents, and dissolved organic carbon in water sampled from 30 monitoring wells in areas of recent residential development, Salt Lake Valley, Utah

Table 3. Concentration and detection frequency of pesticides detected in water sampled from 30 monitoring wells in areas of recent residential development, Salt Lake Valley, Utah.

Table 4. Concentration and detection frequency of volatile organic compounds detected in water sampled from 30 monitoring wells in areas of recent residential development, Salt Lake Valley,

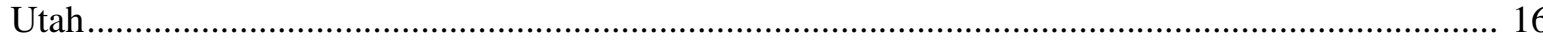

Table 5. Stable isotope ratio, tritium concentration, and apparent age for water sampled from 30 monitoring wells in areas of recent residential development, Salt Lake Valley, Utah................... 36

Table 6. Field parameters for water sampled from monitoring wells in Salt Lake Valley, Utah, 1999 ......... 47

Table 7. Concentration of dissolved major ions in water sampled from monitoring wells in Salt Lake

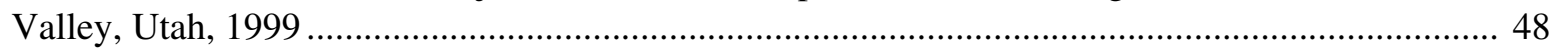

Table 8. Concentration of trace elements in water sampled from monitoring wells in Salt Lake Valley,

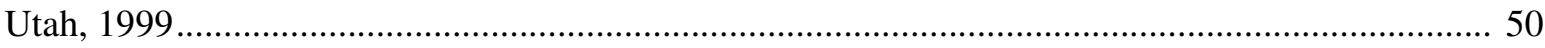

Table 9. Concentration of nutrient constituents and organic carbon in water sampled from monitoring wells in Salt Lake Valley, Utah, 1999 ....................................................................................... 52

Table 10. Pesticides and degradation products analyzed for in water sampled from monitoring wells in Salt Lake Valley, Utah, 1999

Table 11. Concentration of dissolved pesticides detected in water sampled from monitoring wells in Salt Lake Valley, Utah, 1999

Table 12. Volatile organic compounds analyzed for in water sampled from monitoring wells in Salt Lake Valley, Utah, 1999. 58

Table 13. Concentration of volatile organic compounds detected in water sampled from monitoring wells in Salt Lake Valley, Utah, 1999

Table 14. Quality-control data for dissolved major ions in blank water and water sampled from monitoring wells in Salt Lake Valley, Utah, 1999

Table 15. Quality-control data for dissolved trace elements in blank water and water sampled from monitoring wells in Salt Lake Valley, Utah, 1999

Table 16. Quality-control data for dissolved nutrient constituents and organic carbon in blank water and water sampled from monitoring wells in Salt Lake Valley, Utah, 1999.

Table 17. Quality-control data for selected dissolved pesticides in blank water, 1999 .............................. 65

Table 18. Quality-control data for selected volatile organic compounds in blank water, 1999 ...................... 66

Table 19. Percent recovery for pesticide surrogates in blank water and water sampled from monitoring wells in Salt Lake Valley, Utah, 1999.

Table 20. Percent recovery for volatile organic compound surrogates in blank water and water sampled from monitoring wells in Salt Lake Valley, Utah, 1999.

Table 21. Percent recovery for matrix spikes of pesticides in water sampled from monitoring wells in Salt Lake Valley, Utah, 1999

Table 22. Percent recovery for matrix spikes of volatile organic compounds in water sampled from monitoring wells in Salt Lake Valley, Utah, 1999 


\section{CONVERSION FACTORS, DATUMS, AND ABBREVIATED WATER-QUALITY UNITS}

\begin{tabular}{rcl}
\hline Multiply & By & To obtain \\
foot (ft) & 0.3048 & meter \\
gallon (gal) & 3.785 & liter \\
inch (in.) & 25.4 & millimeters \\
mile (mi) & 1.609 & kilometer \\
square mile $\left(\mathrm{mi}^{2}\right)$ & 2.59 & square kilometer \\
\hline
\end{tabular}

Water temperature in degrees Celsius $\left({ }^{\circ} \mathrm{C}\right)$ and degrees Fahrenheit $\left({ }^{\circ} \mathrm{F}\right)$ may be converted by using the following equations:

$$
\begin{aligned}
{ }^{\circ} \mathrm{F} & =1.8\left({ }^{\circ} \mathrm{C}\right)+32 \\
{ }^{\circ} \mathrm{C} & =\left({ }^{\circ} \mathrm{F}-32\right) / 1.8
\end{aligned}
$$

Vertical coordinate information is referenced to the North American Vertical Datum of 1929 (NAVD 29). Horizontal coordinate information is referenced to the North American Datum of 1983 (NAD 83).

Concentration of chemical constituents in water is reported either in milligrams per liter $(\mathrm{mg} / \mathrm{L})$ or micrograms per liter $(\mu \mathrm{g} / \mathrm{L})$. Milligrams per liter and micrograms per liter are units expressing the concentration of chemical constituents in solution as weight (grams) of solute per unit volume (liter) of water. A liter of water is assumed to weigh 1 kilogram, except for brines or water at high temperatures because of changes in the density of the water. For concentrations less than $7,000 \mathrm{mg} / \mathrm{L}$ or $7,000,000 \mu \mathrm{g} / \mathrm{L}$, the numerical value is the same as for concentrations in parts per million or parts per billion, respectively.

Specific conductance is reported in microsiemens per centimeter at 25 degrees Celsius $(\mu \mathrm{S} / \mathrm{cm})$. Radon concentration in water is reported as picocuries per liter $(\mathrm{pCi} / \mathrm{L})$. Stable isotope ratios are reported as per mil, which is equivalent to parts per thousand. Tritium concentration in water is reported as tritium units (TU). The ratio of 1 atom of tritium to $10^{18}$ atoms of hydrogen is equal to 1 $\mathrm{TU}$ or $3.2 \mathrm{pCi} / \mathrm{L}$. Chlorofluorocarbons measured in picograms per kilogram (pg/kg) are equivalent to parts per quadrillion. 


\title{
Quality and Sources of Shallow Ground Water in Areas of Recent Residential Development in Salt Lake Valley, Salt Lake County, Utah
}

\author{
By Susan A. Thiros
}

\section{ABSTRACT}

Residential and commercial development of about 80 square miles that primarily replaced undeveloped and agricultural areas occurred in Salt Lake Valley, Utah, from 1963 to 1994. This study evaluates the occurrence and distribution of natural and anthropogenic compounds in shallow ground water underlying recently developed (post 1963) residential and commercial areas.

Monitoring wells from 23 to 153 feet deep were installed at 30 sites. Water-quality data for the monitoring wells consist of analyses of field parameters, major ions, trace elements, nutrients, dissolved organic carbon, pesticides, and volatile organic compounds.

Dissolved-solids concentration ranged from 134 to 2,910 milligrams per liter $(\mathrm{mg} / \mathrm{L})$ in water from the 30 monitoring wells. Dissolved arsenic concentration in water from 12 wells exceeded the drinking-water maximum contaminant level of 10 micrograms per liter. Water from monitoring wells in the northwestern part of the valley generally contained higher arsenic concentrations than did water from other areas. Nitrate concentration in water sampled from 26 of the 30 monitoring wells (86.7 percent) was higher than a background level of $2 \mathrm{mg} / \mathrm{L}$, indicating a possible human influence. Nitrate concentrations ranged from less than 0.05 to $13.3 \mathrm{mg} / \mathrm{L}$.

Fifteen of the 104 pesticides and pesticide degradation products analyzed for were detected in 1 or more water samples from the monitoring wells. No pesticides were detected at concentrations that exceeded U.S. Environmental Protection Agency drinking-water standards or guidelines for 2002. The high detection frequency of atrazine, a restricted-use pesticide, in residential areas on the west side of Salt Lake Valley may be the result of application in agricultural or industrial areas that have been converted to residential uses or application in areas upgradient from the residential areas that was then transported by ground water.

Fifteen of the 86 volatile organic compounds analyzed for were detected in 1 or more water samples from the monitoring wells. The most frequently detected volatile organic compounds were chloroform (90 percent), bromodichloromethane (56.7 percent), tetrachloroethylene (53.3 percent), and 1,1,1trichloroethane (50 percent). The widespread occurrence of chloroform and bromodichloromethane in shallow ground water is likely a result of the recharge of chlorinated public-supply water used to irrigate lawns and gardens in residential areas of Salt Lake Valley. Tetrachloroethylene (PCE), primarily used as a dry cleaning agent and solvent, was detected in water from 16 wells.

On the basis of stable isotope ratios, ground water from the monitoring wells is a mixture of varying amounts of local precipitation and surface water that has been subjected to evaporation. Because of evaporation, canal water diverted from the Jordan River and used for irrigation is more enriched in deuterium and oxygen- 18 relative to precipitation occurring locally or on the adjacent 
mountains. Several wells on the east side of the valley are upgradient from canals that divert water from the Jordan River but contain a component of water that has been concentrated by evaporation. Chloroform was detected in water from these wells; thus, water is likely a mixture of infiltration from local precipitation and seepage of water used for public supply.

Water from most of the wells had a tritium concentration from 10 to 20 tritium units, a range that most likely is made up of water recharged from the present to about 15 years ago and within the time frame of residential development in the area of the wells. The correlation between tritium concentration in recently recharged ground water and in precipitation indicates that most or all of the water in the shallow ground-water system is from the land surface with little or no mixing with older water. Ground water from most of the monitoring wells was contaminated with chlorofluorocarbons, which also indicates that the water has been in contact with the land surface.

The shallow and deeper ground-water systems in the southeastern part of the valley are separated by sequences of fine-grained deposits that perch the shallow ground water and confine the deeper aquifer. Subsurface inflow from the Wasatch Range is the main source of recharge to the deeper aquifer compared to local precipitation and unconsumed irrigation water that recharges the shallow ground-water system. As a result, the deeper aquifer in this part of the valley is probably more isolated from activities occurring at the land surface that can affect the quality of shallow ground water. Water from local precipitation and seepage from irrigation and canals, primary sources of recharge to the shallow aquifer, also may be major sources of recharge to the deeper aquifer in the southwestern part of Salt Lake Valley where thin or discontinuous confining layers are present. Where this is the case, activities occurring at land surface have the potential to affect the water quality of the deeper aquifer.

No correlation was determined between the percentage of residential land use surrounding the monitoring wells and the concentration of dissolved solids, arsenic, atrazine and its degradation products, prometon, chloroform, or nitrate in water sampled from the wells. Relatively low concentrations of chloroform corresponded to the four highest concentrations of atrazine and its degradation products, probably because of atrazine use on agricultural or nonirrigated industrial and vacant land.

\section{INTRODUCTION}

Ground water is used for public supply in Salt Lake Valley and accounts for about one third of the water used. Withdrawals from the principal aquifer in Salt Lake Valley are regulated and limited by the Utah Division of Water Rights because the resource is overallocated and can be adversely affected by large waterlevel declines and water-quality degradation. Water from the overlying shallow aquifer is not currently used for public supply and has limited use for stock and domestic supply. Leakage from the shallow aquifer to the deeper principal aquifer is possible where a downward gradient exists and confining layers are thin and/or discontinuous. Because of this connection and an increased demand for water caused by population growth, more information is needed about the shallow ground-water resource in the valley.

Residential and commercial development of about $80 \mathrm{mi}^{2}$ that primarily replaced undeveloped and agricultural areas occurred in Salt Lake Valley, Utah, from 1963 to 1994. The chemical composition and effects of human activities on the quality of shallow ground water in the recently developed residential and commercial areas were studied as part of the U.S. Geological Survey (USGS) National Water-Quality Assessment (NAWQA) program. The Great Salt Lake Basins study unit is 1 of more than 50 study areas selected to meet the objectives of the NAWQA program. The land-use study in Salt Lake Valley consisted of 30 monitoring wells installed and sampled in 1999 in residential/commercial areas where shallow ground water has the potential to move to the deeper aquifer used for public supply. The water samples were analyzed for major ions, trace elements, radon, nutrients, pesticides, and volatile organic compounds (VOCs). Analyses also were done to determine the source and time of recharge of the shallow ground water. 


\section{Purpose and Scope}

The purpose of this report is to evaluate the occurrence and distribution of natural and anthropogenic compounds in shallow ground water underlying areas of recently developed (post 1963) residential and commercial land use. The report describes the water quality in the shallow ground-water system and relates it to natural and anthropogenic factors, such as surrounding land uses and associated human activities. It also presents information on the sources and time of recharge on the basis of stable isotope and age-dating methods.

\section{Description of Study Area}

Salt Lake Valley is an urban area bounded by the Wasatch Range, Oquirrh Mountains, Traverse Mountains, and Great Salt Lake (fig. 1). It is about 28 mi long and $18 \mathrm{mi}$ wide and generally corresponds to the populated part of Salt Lake County, which contains the Salt Lake City metropolitan area. The population in Salt Lake County in 2000 was about 898,000 (U.S. Census Bureau, 2002), and is growing rapidly. The population almost doubled between 1963 and 1994, corresponding to a large increase in land developed for residential and commercial use. Population in Salt Lake County is projected to be about 1,029,000 in 2010 and 1,233,000 in 2020 (Wasatch Front Regional Council, 2000), which will require more water for public supply. Because the natural boundaries of the valley restrict expansion of residential areas, population growth will occur mainly through increased population density. Changes in land use resulting from population growth will likely affect shallow groundwater quality through changes in sources and quality of recharge.

Mountain streams draining the Wasatch Range discharge into the Jordan River, which flows north along the axis of the valley and discharges into Great Salt Lake. The climate in Salt Lake Valley is semiarid, with a 1961-90 average annual precipitation of about 10 to 20 in. Lawns and gardens in the valley require irrigation to supplement precipitation during the growing season.

\section{Ground-Water Hydrology}

A generalized model of the saturated basin-fill deposits in Salt Lake Valley consists of a relatively deep unconfined aquifer near the mountain fronts that becomes confined toward the center of the valley by layers of fine-grained deposits (fig. 2). Collectively, the deeper aquifers are known as the principal aquifer. Overlying the deeper confined aquifer is a shallow, generally unconfined aquifer. The primary recharge area for the principal aquifer is near the mountain fronts where there are no substantial layers of finegrained deposits to impede downward movement of water. Leakage of water from the shallow aquifer to the deeper confined aquifer is possible where a downward gradient exists and confining layers are thin or discontinuous. These conditions can exist in the secondary recharge area and were mapped by Anderson and others (1994, p. 6). A discharge area exists where there is an upward gradient from the deeper confined aquifer to the overlying shallow aquifer. Discharge areas generally exist in the center of the valley (fig. 2) along the Jordan River (fig. 3). Recharge and discharge areas in Salt Lake Valley are shown in figure 3 .

Overlying the confining layers is shallow ground water that is either localized in extent because it is perched on fine-grained deposits or is more laterally continuous and forms an aquifer. The shallow aquifer in the valley is generally unconfined, although in some areas the first saturated zone in the subsurface was encountered beneath a confining layer (Thiros, 2003). The shallow aquifer is susceptible to contamination from activities related to land use because of its proximity to land surface and the absence of a thick confining layer. The deeper unconfined aquifer also is vulnerable because of a lack of confining layers that can impede the downward movement of contaminated ground water. Movement of contaminated water from the shallow aquifer and the deeper unconfined aquifer can degrade water quality in the deeper confined aquifer. Hydrogeologic information for the shallow basin-fill deposits collected during the land-use study is presented in Thiros (2003). Faults within and bounding the basin-fill deposits may affect ground-water movement in the valley. Water from wells in the northwestern part of the valley near faults generally is warmer, indicating movement from greater depths. 


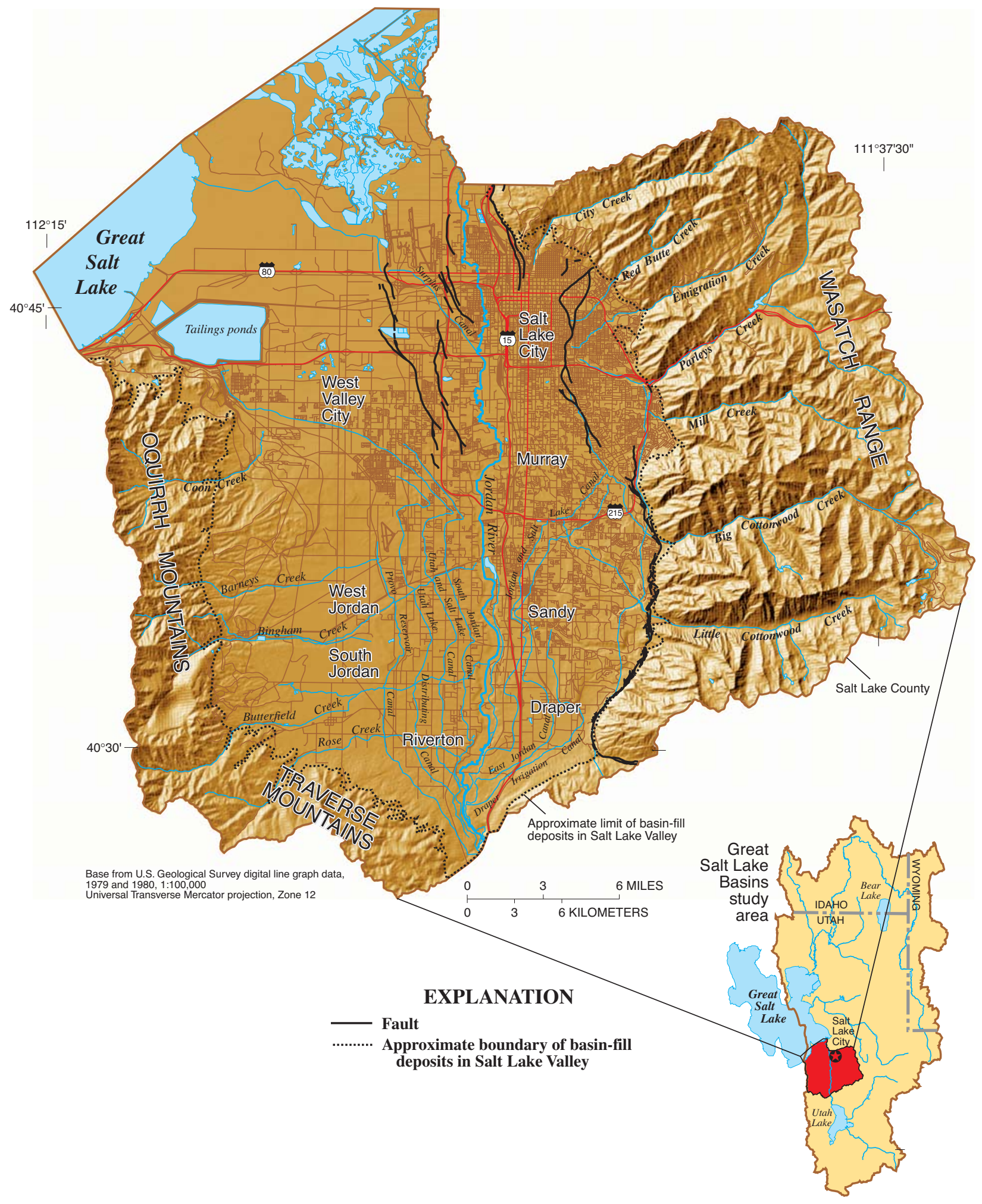

Figure 1. Location and geographic features of Salt Lake Valley, Utah. 


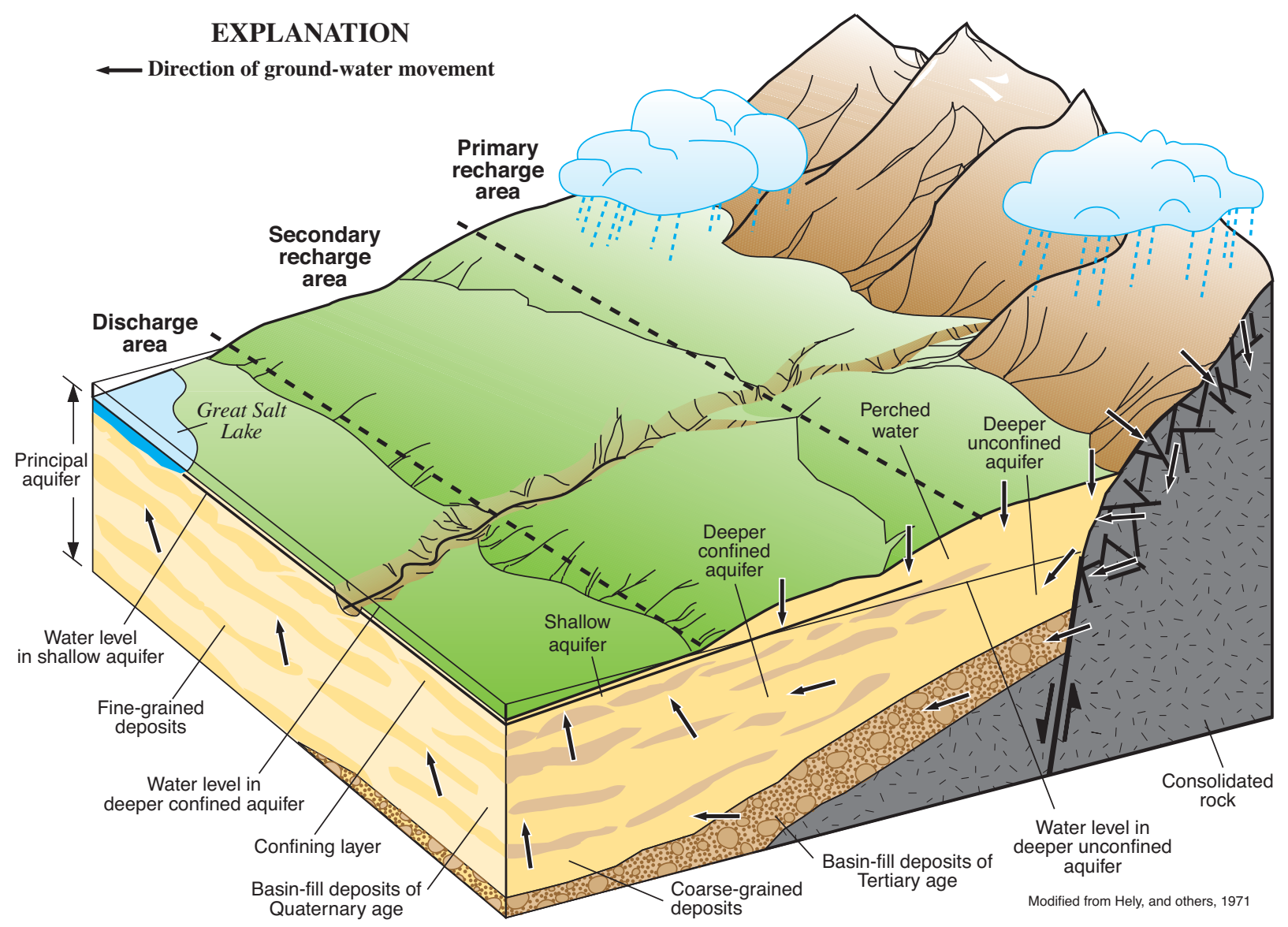

Figure 2. Generalized block diagram showing the basin-fill deposits and ground-water flow system in Salt Lake Valley, Utah.

\section{Land Use}

Historically, much of the industrial land use in Salt Lake Valley was located near the Jordan River with the urban area centered in the northeastern part of the valley. Agricultural land in the valley decreased from $145 \mathrm{mi}^{2}$ in 1960 to $67 \mathrm{mi}^{2}$ in 1994 , while urban land increased from 89 to $198 \mathrm{mi}^{2}$ in the same period (Utah Department of Natural Resources, Division of Water Resources, 1999). Land use in urban areas of the valley in 1994 was about 63 percent residential, 6 percent commercial, 14 percent industrial, and 17 percent other (includes open spaces, idle spaces, transportation, and utilities) (Utah Department of Natural Resources, Division of Water Resources, 1995) (fig. 4). Many of the recently developed residential/commercial areas overlie the secondary recharge areas of the basin-fill ground-water system where a downward gradient exists between the shallow and deeper aquifers.

\section{Acknowledgments}

The USGS thanks the landowners and the officials of municipalities and Salt Lake County who allowed USGS personnel access to their properties for the purpose of installing and sampling the land-use study monitoring wells.

\section{STUDY DESIGN AND METHODS}

The design for NAWQA urban land-use studies focuses on the quality of recently recharged ground water in urban settings and its relation to natural factors and human activities. A study plan was provided to ensure consistency of data collection and study design (Squillace and Price, 1996) and allows for comparison among land-use studies from across the country. 


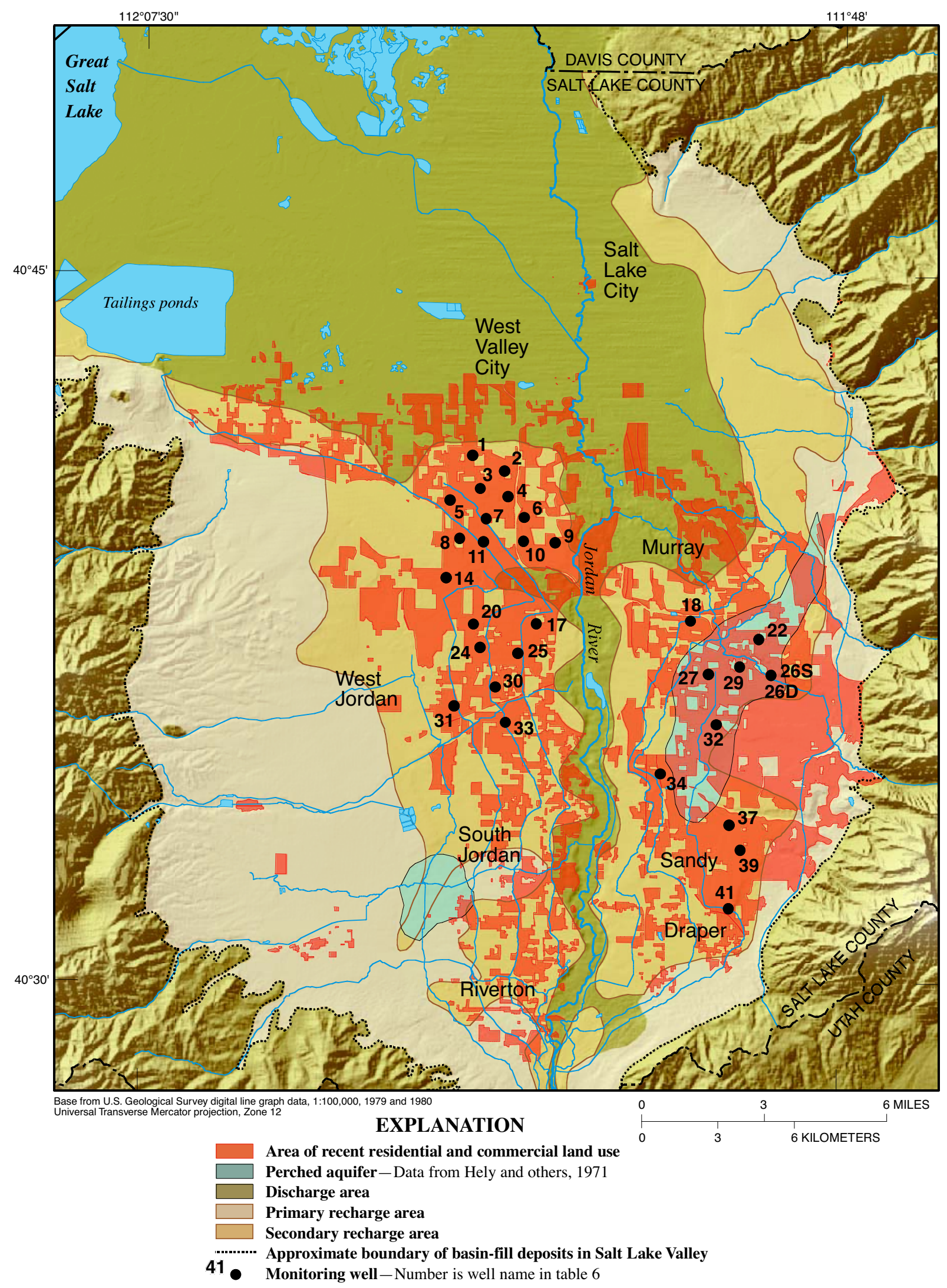

Figure 3. Location of recharge and discharge areas and monitoring wells installed in areas of recent residential development, Salt Lake Valley, Utah. 


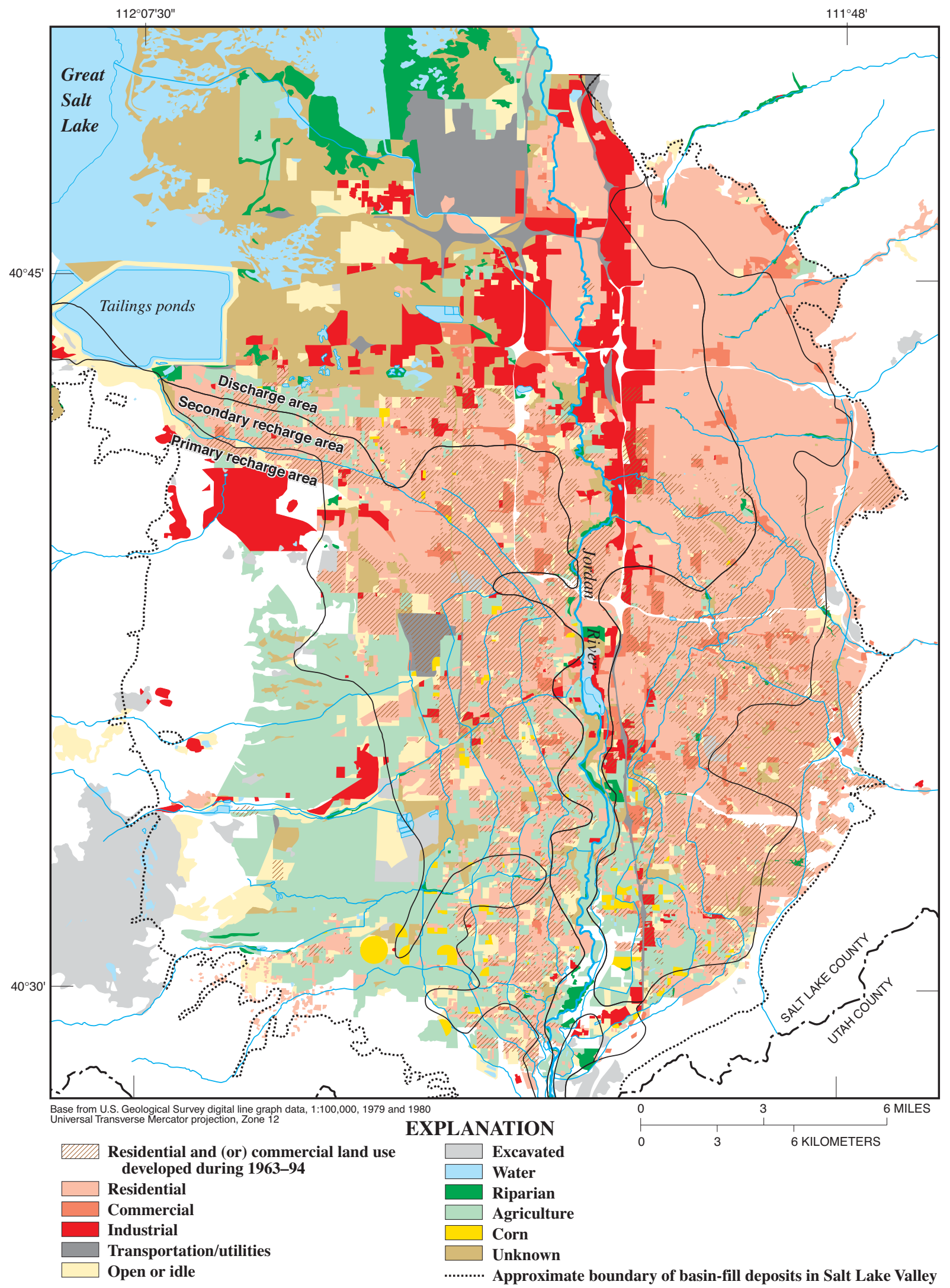

Figure 4. Land use in Salt Lake Valley, Utah, 1994. 


\section{Site Selection}

Potential well locations were selected by using a computerized, stratified random selection process (Scott, 1990) to ensure that the data collected are unbiased and representative of the quality of water underlying recently developed residential and commercial areas. The program selected 41 sites in Salt Lake Valley that met the study criteria: (1) a location in residential and commercial areas developed during 1963-94, (2) a downward gradient between the shallow and deeper aquifers, and (3) a minimum distance between each site of $0.62 \mathrm{mi}$ ( 1 kilometer). Areas developed after 1994 were excluded from this study because of the time necessary for new construction to affect the ground-water system (Squillace and Price, 1996). Areas developed before 1963, such as downtown Salt Lake City, also were excluded because of a greater potential for the land use to have changed with time. The sites were checked for depth to ground water, access, and permission to drill from the landowner.

Monitoring wells were installed at 30 of the 41 sites according to NAWQA protocols (Lapham and others, 1995) and were completed in the shallowest water-bearing zone capable of supplying water (fig. 3). The monitoring wells ranged from 23 to $153 \mathrm{ft}$ deep and generally were completed with a $10-\mathrm{ft}$ length of screen about $5 \mathrm{ft}$ below the water table (table 1). One site was completed with two wells to determine variations in water quality of the shallow aquifer with depth (well 26S is screened from 26 to $31 \mathrm{ft}$ below land surface and well 26D is screened from 62 to $72 \mathrm{ft}$ below land surface). The water level at another site dropped below the bottom of the well and no water sample was collected. Water levels in the wells range from about 5 to $135 \mathrm{ft}$ below land surface.

Land-use characteristics within a 1,640-ft (500meter) radius around each monitoring well were determined from aerial photographs taken in September 1999. Land uses shown on the photographs were field checked and documented by using procedures described in Koterba (1998). The land-use data for this study are plotted as percentages of the total on figure 5. Single and multifamily residences were the most common land use within the prescribed radius of the monitoring wells and ranged from 24 to 96 percent of the area with an average of 70 percent. Other land uses mapped within the radius of the wells include commercial, schools, churches, parks, golf courses, agricultural, roads, and barren property. The amount of commercial land use in the radius around each monitoring well ranged from 0 to 40 percent.

\section{Sample Collection and Analysis}

Ground-water samples were collected in the summer and fall of 1999 by using a stainless-steel submersible pump and fittings connected to Teflon tubing. Samples were collected and processed according to protocols in Koterba and others (1995). Each monitoring well was purged of three to five casing volumes of water prior to sampling. Water temperature, $\mathrm{pH}$, specific conductance, dissolved oxygen, turbidity, discharge, and depth to water were monitored periodically during the purge cycle. Groundwater samples were collected after measurements of these parameters had stabilized. Analytical results for the samples are presented in tables 6 to 13 (appendix).

Five wells were sampled in the spring and fall of 2000 and the fall of 2001 in addition to the land-use study sampling done in 1999 to determine if seasonal changes in water quality occurred. Two of the wells are located on the west side of the valley (wells 5 and 33) and three are on the east side (wells 26D, 27, and 32). These monitoring wells will be sampled on a biennial schedule after the study to monitor long-term waterquality trends in the residential land-use study area. The samples will be analyzed for major ions, trace elements, radon, nutrients, pesticides, and volatile organic compounds (VOCs).

Water samples were analyzed for sulfide and chlorine in the field with a portable spectrophotometer. Sulfide concentration was measured to help determine oxidation/reduction conditions. Chlorine concentration was measured to determine if chlorinated water was present in the ground-water sample. Premeasured amounts of reagent in vacuum-sealed ampoules were mixed with the water sample after the ampoule seal was broken. Transmittance at a set wavelength through the ampoule containing the water sample and reagent is measured by the spectrophotometer and converted to a concentration on the basis of calibration tables from the reagent supplier. Alkalinity was determined onsite by incremental titration of filtered sample water with sulfuric acid.

The USGS National Water-Quality Laboratory (NWQL) in Denver, Colorado, analyzed the water samples for major ions, nutrients, dissolved organic 
Table 1. Description of 30 monitoring wells sampled in Salt Lake Valley, Utah, 1999

[Well identifier, see figure 3 for well location; residential land use within 1,640 feet of well]

\begin{tabular}{|c|c|c|c|c|c|c|c|}
\hline \multirow[t]{2}{*}{$\begin{array}{c}\text { Well } \\
\text { identifier }\end{array}$} & \multirow[t]{2}{*}{$\begin{array}{c}\text { Area of } \\
\text { valley }\end{array}$} & \multirow{2}{*}{$\begin{array}{l}\text { Residential } \\
\text { land use } \\
\text { (percent) }\end{array}$} & $\begin{array}{l}\text { Altitude } \\
\text { of land } \\
\text { surface }\end{array}$ & $\begin{array}{l}\text { Well } \\
\text { depth }\end{array}$ & $\begin{array}{c}\text { Top of } \\
\text { screened } \\
\text { interval }\end{array}$ & $\begin{array}{c}\text { Bottom of } \\
\text { screened } \\
\text { interval }\end{array}$ & $\begin{array}{l}\text { Water level } \\
\text { March } 2000\end{array}$ \\
\hline & & & \multicolumn{5}{|c|}{ (feet below land surface) } \\
\hline 1 & northwest & 84.5 & 4,308 & 48.5 & 38 & 48 & 32.77 \\
\hline 2 & northwest & 64.0 & 4,294 & 38.5 & 28 & 38 & 19.55 \\
\hline 3 & northwest & 89.3 & 4,371 & 114 & 103 & 113 & 79.96 \\
\hline 4 & northwest & 23.6 & 4,331 & 38.5 & 28 & 38 & 14.01 \\
\hline 5 & northwest & 39.4 & 4,426 & 43.5 & 33 & 43 & 27.59 \\
\hline 6 & northwest & 50.6 & 4,324 & 38.5 & 28 & 38 & 23.46 \\
\hline 7 & northwest & 71.6 & 4,396 & 43.5 & 33 & 43 & 27.09 \\
\hline 8 & northwest & 71.8 & 4,487 & 67.5 & 57 & 67 & 63.37 \\
\hline 9 & northwest & 41.0 & 4,312 & 38.5 & 28 & 38 & 12.57 \\
\hline 10 & northwest & 76.9 & 4,350 & 83.5 & 73 & 83 & 67.94 \\
\hline 11 & northwest & 83.7 & 4,462 & 83.5 & 73 & 83 & 70.75 \\
\hline 14 & southwest & 70.5 & 4,579 & 48.5 & 38 & 48 & 27.97 \\
\hline 17 & southwest & 57.8 & 4,380 & 38.5 & 28 & 38 & 17.72 \\
\hline 18 & east & 79.5 & 4,411 & 106 & 95 & 105 & 76.85 \\
\hline 20 & southwest & 72.3 & 4,477 & 92.5 & 82 & 92 & 84.66 \\
\hline 22 & east & 77.9 & 4,538 & 36 & 25.5 & 35.5 & 21.61 \\
\hline 24 & southwest & 93.1 & 4,473 & 124 & 113 & 123 & 81.98 \\
\hline 25 & southwest & 96.1 & 4,414 & 68.5 & 58 & 68 & 49.67 \\
\hline $26 \mathrm{D}$ & east & 81.8 & 4,591 & 77.5 & 62 & 72 & 32.77 \\
\hline $26 \mathrm{~S}$ & east & 81.8 & 4,591 & 31.5 & 26 & 31 & 30.43 \\
\hline 27 & east & 90.4 & 4,499 & 73.5 & 63 & 73 & 58.69 \\
\hline 29 & east & 91.0 & 4,532 & 34 & 23.5 & 33.5 & 9.02 \\
\hline 30 & southwest & 66.7 & 4,455 & 68.5 & 58 & 68 & 58.12 \\
\hline 31 & southwest & 72.8 & 4,562 & 154 & 143 & 153 & 143.19 \\
\hline 32 & east & 35.0 & 4,640 & 88.5 & 78 & 88 & 76.18 \\
\hline 33 & southwest & 38.9 & 4,466 & 95.5 & 85 & 95 & 74.14 \\
\hline 34 & east & 49.7 & 4,486 & 77.5 & 67 & 77 & 57.81 \\
\hline 37 & east & 92.9 & 4,725 & 73 & 62.5 & 72.5 & 45.18 \\
\hline 39 & east & 84.0 & 4,758 & 106 & 95.5 & 106 & 94.02 \\
\hline 41 & east & 66.9 & 4,550 & 23 & 12.5 & 22.5 & 5.48 \\
\hline
\end{tabular}

carbon (DOC), selected trace elements, radon, pesticides, and VOCs. Major ions and trace elements were analyzed by using inductively coupled plasma/mass spectrometry, atomic absorption spectrometry, or ion chromatography (Fishman and Friedman, 1989; Fishman, 1993; and Faires, 1993). Nutrient concentrations were determined by colorimetry (Fishman, 1993; Patton and Truitt, 1992). DOC was analyzed for by using ultraviolet-promoted persulfate oxidation and infrared spectrometry (Brenton and Arnett, 1993). Radon was analyzed for by using liquid scintillation (American Society for Testing and Materials, 1996). Filtered water samples were analyzed for 86 pesticides by using capillary column gas chromatography/mass spectrometry (Zaugg and others, 1995) and 65 pesticides by using highperformance liquid chromatography/mass spectrometry (HPLC/MS) (Furlong and others, 2001). The HPLC/MS method was used to analyze the samples before its final approval; therefore, concentrations of pesticides analyzed by this method are considered provisional. Unfiltered water samples were analyzed for 86 VOCs by using purge and trap capillary column gas chromatography/mass spectrometry (Conner and others, 1998).

Analyses of the stable isotopes of water, deuterium and oxygen-18 were done at the USGS Stable Isotope Laboratory in Reston, Virginia. The 


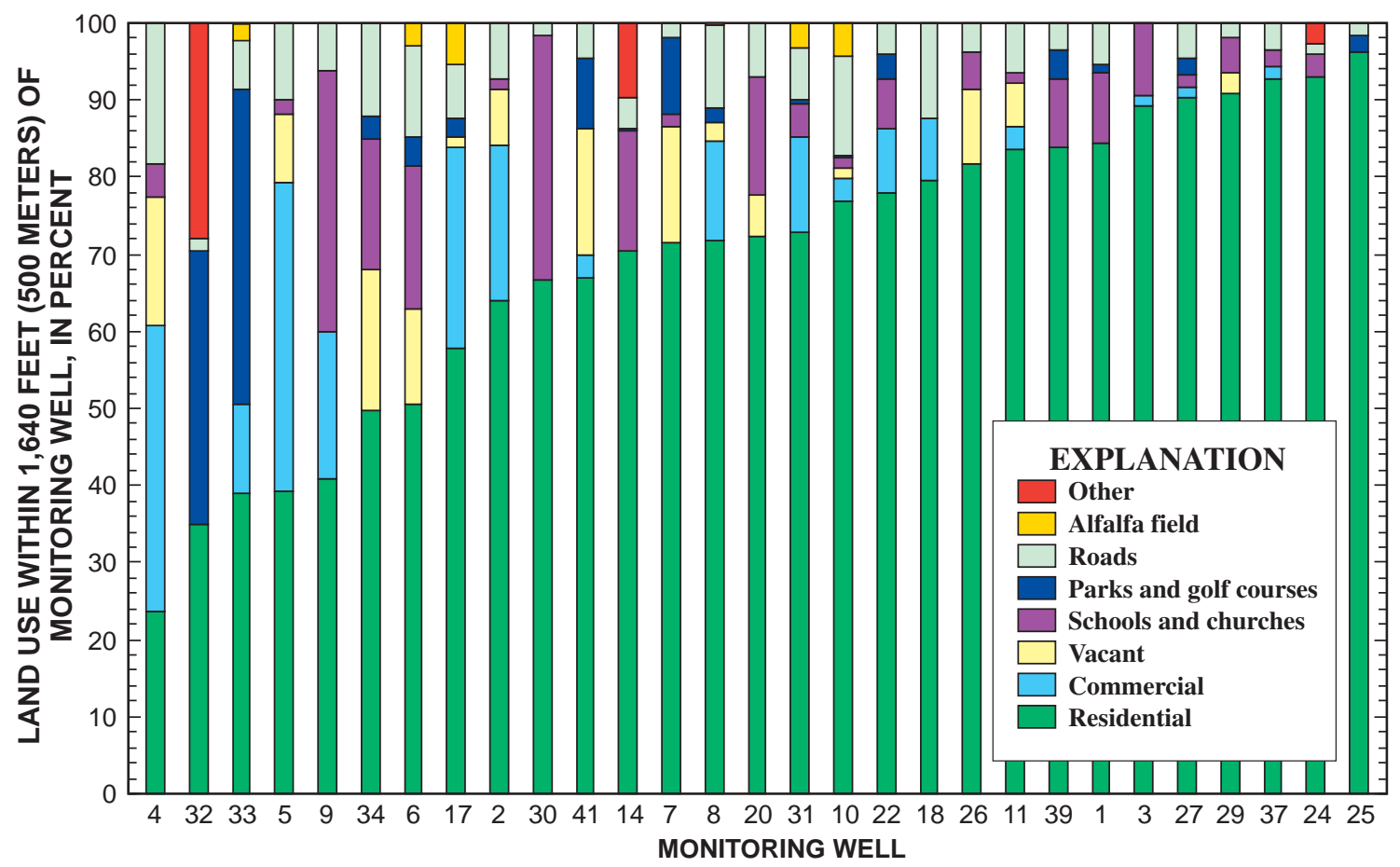

Figure 5. Percentage of land-use type mapped within a 1,640-foot radius of monitoring wells in Salt Lake Valley, Utah.

deuterium analysis uses a hydrogen equilibration method (Coplen and others, 1991) and the oxygen-18 analysis uses a carbon dioxide equilibration technique (Epstein and Mayeda, 1953). Analytical uncertainties for delta deuterium and delta oxygen-18 values are 2 and 0.2 per mil, respectively. Chlorofluorocarbons (CFCs) were analyzed at the USGS CFC Laboratory in Reston, Virginia, by using purge and trap gas chromotography (Busenberg and Plummer, 1992). The detection limit for CFCs is about $0.3 \mathrm{pg} / \mathrm{kg}$ of water, which is equivalent to 0.3 parts per quadrillion (Plummer and Friedman, 1999). The University of Utah, Department of Geology and Geophysics, Tritium and Noble Gases Laboratory in Salt Lake City, Utah, analyzed the water samples for tritium and helium-3. Tritium concentrations were determined by helium ingrowth (Bayer and others, 1989). The method involves degassing the sampled water and then isolating it under a vacuum in a special container. The sample is stored from 1 month to 1 year, and then the concentration of helium-3, the daughter product of tritium, is measured by using a magnetic sector-field mass spectrometer.
VOC's that are not detected in a water sample are reported as less than the laboratory reporting level (LRL). The LRL for each VOC represents the minimum concentration that can be identified, measured, and reported with 99 percent confidence (Childress and others, 1999). All other constituents or pesticide compounds that are not detected in a water sample are reported as less than the minimum reporting level (MRL). The MRL is defined by the NWQL (Timme, 1995) as the smallest measured concentration of a constituent that may be reliably measured by using a given analytical method. The MRL or LRL for each constituent or compound indicates relative analytical precision and detection sensitivity, but some concentrations are reported below the reporting level if the identification criteria for the method were met. Concentrations for detections below MRLs or LRLs are designated as estimated values. The MRLs for pesticides and LRLs for VOCs analyzed for by the NAWQA program are lower than those of analyses done for regulatory purposes. 
Concentrations of water-quality constituents and compounds were compared to the drinking-water standards for 2002 set by the U.S. Environmental Protection Agency (USEPA) (U.S. Environmental Protection Agency, 2002). The maximum contaminant level (MCL) is the maximum concentration of a contaminant permissible in a public-water system. The MCL primarily applies to water sampled from distribution lines and at taps after being disinfected. MCLs are based on a level at which no known or anticipated adverse effects on human health occur and which allows an adequate margin of safety, but also considers the cost and feasibility of meeting the standard. The lifetime health advisory level (HAL) is the concentration of a chemical in drinking water that is not expected to cause any adverse noncarcinogenic effects during a lifetime of exposure (U.S.

Environmental Protection Agency, 2002). It is based on health effects information and is provided as technical guidance for regulatory and management officials.

\section{Quality Assurance}

A quality-assurance program was used in the field (Koterba and others, 1995) and in the laboratory to evaluate the bias and variability of the analytical results and to ensure data reliability. Quality-control samples were collected as part of sampling the 30 monitoring wells and included 6 field-blank samples for major ions, nutrients, VOCs, pesticides, and trace elements; 6 source-solution blank samples for DOC and 5 for VOCs; 1 trip-blank sample for VOCs; 3 replicate samples for major ions, nutrients, trace elements, and radon; 3 field-spiked samples for VOCs and selected pesticides; and 3 laboratory-spiked samples for selected pesticides. Analytical results for the field-blank and ground-water replicate samples are listed in the tables 14-18 (appendix).

Field-blank samples were collected to evaluate contamination introduced during sample collection, processing, and analysis. Water certified to have less than the MRL or LRL for the analyzed constituents and compounds was pumped through the sampling pump, tubing, and other sampling equipment in the same manner as a regular ground-water sample. Relatively large volumes of water flowed through the sampling equipment prior to collection of a ground-water sample, whereas a much smaller amount of blank water flowed through the system prior to collection of the field-blank sample. This additional flushing and rinsing with ground water is believed to have minimized residual concentrations possibly left after the equipment cleaning procedure.

DOC was detected in water from all six fieldblank samples, three at concentrations that were less than the lowest concentration measured in the groundwater samples and three within the range of measured concentrations. Because DOC was not detected in water from the source-solution blank samples, it likely results from residual cleaning agents in the sampling equipment (rinsed with 1 to 3 gal of blank water). Additional rinsing with ground water during the purging cycle of sampling (usually more than 20 gal) likely reduces DOC concentrations in the environmental samples to below those determined for the field blanks. Some of the DOC measured in water from the wells may be from the sampling equipment; therefore, DOC concentrations may be greater than what was actually present in the aquifer. Caution should be used in interpreting these data.

Nitrate plus nitrite and ammonia each were detected in one field-blank sample and ammonia plus organic nitrogen was detected in two field-blank samples. Concentrations of ammonia and ammonia plus organic nitrogen in the field-blank samples were within the range of concentrations measured in the ground-water samples; therefore, data for these constituents should be interpreted with caution. The concentration of nitrate plus nitrite in water from the field-blank sample is much lower than that for water from most of the environmental samples, and any residual contamination is probably diluted to less than the reporting level by the purging of ground water through the sampling lines. Nitrate plus nitrite concentrations measured in the ground-water samples are assumed to be uncontaminated on the basis of the field-blank data.

Zinc was detected in water from five of the six field blanks at concentrations in the range of those determined for the ground-water samples; therefore, the ground-water data are likely biased. Small amounts of chromium, nickel, and copper also were detected in water from two to four of the field blanks. Chromium and nickel are used in stainless steel and may be coming from the stainless steel connections used on the Teflon tubing. The concentration of these constituents in the field-blank samples generally is lower than those 
in the ground-water samples, but contamination may bias concentrations that are in the same range. Caution should be used in interpreting these data.

Of the 104 pesticides or pesticide breakdown products analyzed for, only 4 were detected in fieldblank samples. The herbicides cycloate, fenuron, and imazaquin were detected in water from one, one, and two field-blank samples, respectively; and in four, zero, and two ground-water samples, respectively, analyzed in the same sample set at the NWQL. These compounds also were detected in water from laboratory blanks at a similar concentration; therefore, their presence in the ground-water and field-blank samples is probably the result of laboratory contamination. Detection of cycloate, fenuron, and imazaquin is questioned; therefore, these compounds are not included in the pesticide data analysis.

The VOCs ethylbenzene, 1,2,4trimethylbenzene, o-ethyltoluene, and $\mathrm{m} / \mathrm{p}$ xylene were detected in two to five field-blank samples at concentrations greater than those estimated for the ground-water samples. The compounds 1,2,3trimethylbenzene, 1,3,5-trimethylbenzene, and oxylene also were detected in a field-blank sample and in a ground-water sample at similar concentrations. No VOCs were detected in the source-solution blanks or in the trip blank. These compounds were probably introduced into the blank sample when the blank water was poured into a cylinder containing the sampling pump. The atmosphere can receive these compounds, in addition to benzene and toluene, from the incomplete combustion of gasoline used to power the generator or nearby vehicles. Ground-water samples are not exposed to air except when they are transferred from the sample-collection chamber to the preservation chamber, so the likelihood of contamination is less than when collecting the field-blank sample. Detection of the compounds listed above in ground water is questioned and is not included in the VOC data analysis.

Sequential replicate ground-water samples were collected from three wells to determine the concentration variability for radon, major ions, and trace elements. Replicate samples collected from two wells were analyzed for DOC and nutrients.

Concentrations for most constituents in the sample pairs were within 10 percent. Low concentrations of ammonia plus organic nitrogen, orthophosphorus, fluoride, and copper resulted in maximum differences between the sample pairs of about 25 percent. The zinc concentration in water from one replicate sample was twice as much as was measured in the ground-water sample and may be related to contamination.

Surrogate pesticide and VOC compounds were added in known concentrations to the ground-water and blank-water samples and percent recovery was determined for each surrogate (tables 19 and 20, appendix). These surrogate compounds are similar chemically to other compounds that were analyzed for and provide information on sample-matrix effects and analyte recovery. Pesticide surrogate recovery in the ground-water samples ranged from 73 to 106 percent for alpha-HCH-d6, 41 to an estimated 106 percent for barban, 40 to 98 percent for caffeine, 85 to 141 percent for diazinon, and an estimated 35 to 101 percent for $2,4,5-T$. Relatively low recovery of caffeine and 2,4,5$\mathrm{T}$ in water from wells $6,8,10,11,24,25,30,31$, and 33 (all on the west side of the valley) corresponded with relatively high recovery of the surrogate diazinon. Water from the valley's west side seems to have a different effect on these surrogates than water from the east side. VOC surrogate recovery in the ground-water samples ranged from 88 to 121 percent for 1,2dichloroethane-d4, 73 to 105 percent for 1,4bromofluorobenzene, and 91 to 109 percent for toluene-d8.

Spike solutions containing known concentrations of target VOC and pesticide compounds were added to three replicate ground-water samples (tables 21 and 22, appendix) to determine analyte recovery in the sample matrix and to evaluate the effectiveness of the analytical methods for selected analytes. Recovery of most compounds was within 25 percent of the amount present in the unspiked sample plus the amount added in the spike solution. Recovery of the atrazine degradation products deethylatrazine and 2hydroxyatrazine was less than (34 percent mean recovery) and greater than (140 percent mean recovery), respectively, the amount added to the three matrix-spiked samples. Low mean recovery means that the compound may not have been detected in the sample if present at low concentrations. High mean recovery means that the detections are real, but concentrations may be biased high. Recovery of chloromethane was greater than the amount added to the three matrix-spiked samples (164 percent mean recovery). Water from well 34 had the only detection of chloromethane (estimated at $0.1 \mu \mathrm{g} / \mathrm{L}$ ) in the study, which on the basis of the spike-recovery data may be a higher concentration than actually exists in the aquifer. 
Ninety percent of the ground-water samples from this study analyzed for pesticides with the HPLC/MS method exceeded the recommended 4-day holding time prior to sample extraction (Furlong and others, 2001). Degradation of pesticides during extended sample storage is likely, and concentrations and detection frequencies for the pesticides analyzed by this method may be biased low.

\section{GROUND-WATER OUALITY}

Ground-water quality data for the 30 monitoring wells sampled in recently developed residential areas of Salt Lake Valley consist of field parameters, major ions, trace elements, nutrients, DOC, pesticides, and VOCs. Summary statistics for field parameters, major ions, trace elements, nutrients, and DOC are listed in table 2; pesticides in table 3; and VOCs in table 4. Analytical results for the samples collected from the 30 wells as part of this study are listed in tables 6 to 13 (appendix). Water-quality data for these and other samples discussed in the following sections are also available on the internet at URL

http://waterdata.usgs.gov/ut/nwis/qwdata.

\section{Field Parameters}

Field parameters measured during sampling are depth to water, water temperature, specific conductance, $\mathrm{pH}$, alkalinity, dissolved oxygen, turbidity, chlorine, and sulfide concentration (table 2 and table 6, appendix). Depth to water in the wells ranged from $5.27 \mathrm{ft}$ below land surface at well 41 in the southeastern part of the valley to $135.17 \mathrm{ft}$ below land surface at well 31 in the southwestern part. All of the samples were within the range specified for $\mathrm{pH}$ to meet secondary drinking water regulations (U.S. Environmental Protection Agency, 2002). Turbidity of water sampled from the monitoring wells ranged from 0.1 to 12 nephelometric turbidity units (NTU).

Turbidity measurements can be used to evaluate potential colloidal contributions to measured concentrations of iron, manganese, and other elements. Chlorine was detected in water from eight monitoring wells, seven of which are on the east side of the valley. The chlorine may be from chlorinated water that has recharged the shallow ground-water system because chloroform also was detected in the samples.
The concentration of dissolved oxygen in water from the wells varied from 0.7 to $8.7 \mathrm{mg} / \mathrm{L}$ and provides information on the oxidation-reduction (redox) state of the water. The redox state can affect what constituents are present and at what concentrations. Oxidizing conditions are generally defined by dissolved oxygen concentrations greater than $2.0 \mathrm{mg} / \mathrm{L}$ and no detectable concentrations of nitrite, ammonia, sulfide, iron, or manganese.

Reducing conditions are indicated by dissolved oxygen concentrations less than $2.0 \mathrm{mg} / \mathrm{L}$ and the presence of nitrite, ammonia, sulfide, iron, or manganese. Because dissolved oxygen can be introduced to ground water during the sampling process, these other indicators were used to help determine redox conditions (tables 6 , 7,8 , and 9 , appendix). On the basis of these indicators, 6 wells had water under reducing conditions, 12 wells had water under oxidizing conditions, and the remaining 12 wells had water with dissolved oxygen concentrations greater than $2.0 \mathrm{mg} / \mathrm{L}$, but the presence of nitrite, ammonia, sulfide, iron, or manganese resulted in indefinite conditions. Well 29 was the only well on the east side of the valley with definite reducing conditions.

\section{Inorganic Constituents}

\section{Major lons}

Dissolved-solids concentration (determined as residue at $180^{\circ} \mathrm{C}$ ) ranged from 134 to $2,910 \mathrm{mg} / \mathrm{L}$ in water from the 30 monitoring wells (fig. 6). The secondary drinking-water regulation for dissolved solids of $500 \mathrm{mg} / \mathrm{L}$ (U.S. Environmental Protection Agency, 2002) was exceeded in water from 23 wells. Water from wells on the east and west sides of the valley had median concentrations of 405 and 1,300 $\mathrm{mg} / \mathrm{L}$, respectively. The least mineralized water was from well 26S (fig. 3) next to Little Cottonwood Creek. Water in the creek (USGS site number 10167800) is primarily snowmelt runoff from the Wasatch Range in the spring and early summer and had a dissolved-solids concentration of $67 \mathrm{mg} / \mathrm{L}$ in May 2000. The most mineralized water was from well 20 and contained $1,480 \mathrm{mg} / \mathrm{L}$ of sulfate. Sulfate was the predominant anion in water from the four monitoring wells (wells $10,17,20$, and 24), all on the west side of the valley, with more than 2,000 $\mathrm{mg} / \mathrm{L}$ dissolved solids (table 7, appendix). 
Table 2. Summary of field parameters, inorganic constituents, and dissolved organic carbon in water sampled from 30 monitoring wells in areas of recent residential development, Salt Lake Valley, Utah

[USEPA, U.S. Environmental Protection Agency; —, not applicable or no standard; ${ }^{\circ} \mathrm{C}$, degrees Celsius; $\mu \mathrm{S} / \mathrm{cm}$, microsiemens per centimeter at 25 degrees Celsius; SDWR, Secondary Drinking-Water Regulations; mg/L, milligrams per liter; NTU, nephelometric turbidity units; $\mu \mathrm{g} / \mathrm{L}$, micrograms per liter; MCL, Maximum Contaminant Level; M, presence of constituent verified but not quantified; E, estimated; HAL, Lifetime Health-Advisory Level; pCi/L, picocuries per liter]

\begin{tabular}{|c|c|c|c|c|c|c|}
\hline Parameters, constituents, and reporting units & $\begin{array}{l}\text { Number of } \\
\text { detections }\end{array}$ & $\begin{array}{c}\text { Minimum } \\
\text { reporting level }\end{array}$ & $\begin{array}{c}\text { Minimum } \\
\text { detected } \\
\text { concen- } \\
\text { tration }\end{array}$ & $\begin{array}{l}\text { Maximum } \\
\text { detected } \\
\text { concen- } \\
\text { tration }\end{array}$ & $\begin{array}{l}\text { Median of } \\
\text { detections }\end{array}$ & $\begin{array}{l}\text { USEPA drinking- } \\
\text { water standards or } \\
\text { health advisories }{ }^{1}\end{array}$ \\
\hline \multicolumn{7}{|l|}{ Field parameters } \\
\hline Well depth (feet) & 30 & - & 23 & 153.5 & 68.2 & - \\
\hline Water level (feet) & 30 & - & 5.27 & 135.17 & 30.91 & - \\
\hline Water temperature $\left({ }^{\circ} \mathrm{C}\right)$ & 29 & - & 10.5 & 19 & 16 & - \\
\hline Specific conductance $(\mu \mathrm{S} / \mathrm{cm})$ & 30 & - & 235 & 3,700 & 1,405 & - \\
\hline $\mathrm{pH}$ (standard units) & 30 & - & 6.8 & 7.8 & 7.3 & 6.5-8.5 (SDWR) \\
\hline Alkalinity $\left(\mathrm{mg} / \mathrm{L}\right.$ as $\left.\mathrm{CaCO}_{3}\right)$ & 30 & - & 68 & 659 & 308 & - \\
\hline Oxygen, dissolved (mg/L) & 29 & - & .7 & 8.7 & 5.3 & - \\
\hline Turbidity (NTU) & 30 & - & .1 & 12 & .5 & \\
\hline Chlorine $(\mu \mathrm{g} / \mathrm{L})$ & 8 & 30 & 35 & 100 & 50 & \\
\hline Sulfide $(\mu \mathrm{g} / \mathrm{L})$ & 12 & 10 & 10 & 240 & 10 & \\
\hline \multicolumn{7}{|l|}{ Major ions } \\
\hline Bicarbonate $\left(\mathrm{mg} / \mathrm{L}\right.$ as $\left.\mathrm{HCO}_{3}\right)$ & 30 & - & 82 & 804 & 392 & - \\
\hline Bromide, dissolved (mg/L) & 29 & .01 & .01 & 1.40 & .22 & - \\
\hline Calcium, dissolved (mg/L) & 30 & .01 & 20.6 & 448 & 95.9 & - \\
\hline Chloride, dissolved (mg/L) & 30 & .1 & 12.9 & 456 & 184 & 250 (SDWR) \\
\hline Fluoride, dissolved (mg/L) & 30 & .1 & .1 & 1.9 & .6 & 4.0 (MCL) \\
\hline Iron, dissolved $(\mu \mathrm{g} / \mathrm{L})$ & 11 & 10 & M & 540 & M & 300 (SDWR) \\
\hline Magnesium, dissolved (mg/L) & 30 & .008 & 4.88 & 175 & 39.8 & - \\
\hline Manganese, dissolved ( $\mu \mathrm{g} / \mathrm{L})$ & 24 & 2.2 & E1.4 & 148 & 11.2 & 50 (SDWR) \\
\hline Potassium, dissolved (mg/L) & 30 & .09 & 1.35 & 57.8 & 10.6 & - \\
\hline Silica, dissolved (mg/L) & 30 & .1 & 6.5 & 51.6 & 37 & - \\
\hline Sodium, dissolved (mg/L) & 30 & .1 & 10.3 & 473 & 162 & - \\
\hline Sulfate, dissolved (mg/L) & 30 & .1 & 16.9 & 1,480 & 136 & 250 (SDWR) \\
\hline Dissolved solids, residue at $180^{\circ} \mathrm{C},(\mathrm{mg} / \mathrm{L})$ & 30 & 10 & 134 & 2,910 & 833 & 500 (SDWR) \\
\hline Dissolved solids, sum of constituents (mg/L) & 30 & - & 131 & 2,830 & 856 & 500 (SDWR) \\
\hline \multicolumn{7}{|l|}{ Trace elements } \\
\hline Aluminum, dissolved ( $\mu \mathrm{g} / \mathrm{L})$ & 24 & 1 & 1 & 10 & 2 & 50-200 (SDWR) \\
\hline Antimony, dissolved ( $\mu \mathrm{g} / \mathrm{L})$ & 2 & 1.00 & 1.30 & 1.69 & 1.54 & $6(\mathrm{MCL})$ \\
\hline Arsenic, dissolved $(\mu \mathrm{g} / \mathrm{L})$ & 24 & 1.0 & 1.1 & 19.6 & 10.5 & 10 (MCL) \\
\hline Barium, dissolved $(\mu \mathrm{g} / \mathrm{L})$ & 30 & 1.0 & 11.8 & 255 & 52.4 & $2,000(\mathrm{MCL})$ \\
\hline Beryllium, dissolved ( $\mu \mathrm{g} / \mathrm{L})$ & 0 & 1.00 & - & - & - & 4 (MCL) \\
\hline Cadmium, dissolved ( $\mu \mathrm{g} / \mathrm{L})$ & 0 & 1.00 & - & - & - & $5(\mathrm{MCL})$ \\
\hline Chromium, dissolved ( $\mu \mathrm{g} / \mathrm{L})$ & 23 & 1.0 & E.5 & 4.7 & 1.7 & ${ }^{2} 100$ (MCL) \\
\hline Cobalt, dissolved $(\mu \mathrm{g} / \mathrm{L})$ & 2 & 1.00 & 1.05 & 1.09 & 1.07 & - \\
\hline Copper, dissolved $(\mu \mathrm{g} / \mathrm{L})$ & 26 & 1.0 & 1.0 & 10 & 2.3 & 1,000 (SDWR) \\
\hline Lead, dissolved ( $\mu \mathrm{g} / \mathrm{L})$ & 0 & 1.00 & - & - & - & - \\
\hline Molybdenum, dissolved ( $\mu \mathrm{g} / \mathrm{L})$ & 28 & 1.0 & 1.5 & 99.1 & 5.2 & 40 (HAL) \\
\hline Nickel, dissolved ( $\mu \mathrm{g} / \mathrm{L})$ & 28 & 1.00 & 1.30 & 7.88 & 3.12 & 100 (HAL) \\
\hline Radon-222, total (pCi/L) & 30 & 26 & 243 & 2,190 & 574 & 300 (MCL) \\
\hline Selenium, dissolved $(\mu \mathrm{g} / \mathrm{L})$ & 15 & 1.0 & 1.2 & 13.0 & 2.6 & $50(\mathrm{MCL})$ \\
\hline Silver, dissolved $(\mu \mathrm{g} / \mathrm{L})$ & 0 & 1.0 & - & - & - & 100 (HAL) \\
\hline Uranium, dissolved $(\mu \mathrm{g} / \mathrm{L})$ & 29 & 1.00 & 1.50 & 92.7 & 10.4 & 30 (MCL) \\
\hline Zinc, dissolved $(\mu \mathrm{g} / \mathrm{L})$ & 27 & 1 & 1 & 8 & 3 & 2,000 (HAL) \\
\hline
\end{tabular}


Table 2. Summary of field parameters, inorganic constituents, and dissolved organic carbon in water sampled from 30 monitoring wells in areas of recent residential development, Salt Lake Valley, Utah—Continued

\begin{tabular}{|c|c|c|c|c|c|c|}
\hline Parameters, constituents, and reporting units & $\begin{array}{l}\text { Number of } \\
\text { detections }\end{array}$ & $\begin{array}{c}\text { Minimum } \\
\text { reporting level }\end{array}$ & $\begin{array}{c}\text { Minimum } \\
\text { detected } \\
\text { concen- } \\
\text { tration }\end{array}$ & $\begin{array}{c}\text { Maximum } \\
\text { detected } \\
\text { concen- } \\
\text { tration }\end{array}$ & $\begin{array}{l}\text { Median of } \\
\text { detections }\end{array}$ & $\begin{array}{l}\text { USEPA drinking- } \\
\text { water standards or } \\
\text { health advisories }{ }^{1}\end{array}$ \\
\hline \multicolumn{7}{|l|}{ Nutrients and dissolved organic carbon } \\
\hline Ammonia, dissolved as $\mathrm{N}(\mathrm{mg} / \mathrm{L})$ & 7 & .020 & .021 & .043 & .029 & 30 (HAL) \\
\hline $\begin{array}{l}\text { Ammonia plus organic nitrogen, dissolved as } \\
\mathrm{N}(\mathrm{mg} / \mathrm{L})\end{array}$ & 27 & .10 & E.06 & .34 & .14 & - \\
\hline Carbon, organic, dissolved as $\mathrm{C}(\mathrm{mg} / \mathrm{L})$ & 30 & .30 & .60 & 4.6 & 1.5 & - \\
\hline Nitrite, dissolved as N (mg/L) & 5 & .010 & .012 & .107 & .019 & 1 (MCL) \\
\hline Nitrate plus nitrite, dissolved as $\mathrm{N}$ (mg/L) & 29 & .050 & .200 & 13.3 & 6.85 & 10 (MCL) \\
\hline Phosphorus, dissolved as P (mg/L) & 29 & .004 & .006 & .207 & .033 & - \\
\hline Orthophosphorus, dissolved as $\mathrm{P}$ (mg/L) & 27 & .010 & .015 & .189 & .031 & - \\
\hline
\end{tabular}

${ }^{1}$ U.S. Environmental Protection Agency (2002).

${ }^{2}$ Maximum contaminant level is for total chromium.

Table 3. Concentration and detection frequency of pesticides detected in water sampled from 30 monitoring wells in areas of recent residential development, Salt Lake Valley, Utah

[Maximum contaminant level is the U.S. Environmental Protection Agency established drinking-water standard (U.S. Environmental Protection Agency, 2002). Lifetime health advisory level is defined as the concentration of a chemical in drinking water that is not expected to cause any adverse noncarcinogenic effects for a lifetime of exposure (U.S. Environmental Protection Agency, 2002). E, estimated value; —, not applicable or no standard]

\begin{tabular}{|c|c|c|c|c|c|c|c|c|}
\hline Pesticide & $\begin{array}{l}\text { Trade name(s) or } \\
\text { abbreviation }\end{array}$ & Predominant use & $\begin{array}{c}\text { Number } \\
\text { of detec- } \\
\text { tions }\end{array}$ & $\begin{array}{c}\text { Maxi- } \\
\text { mum } \\
\text { concen- } \\
\text { tration }\end{array}$ & $\begin{array}{c}\text { Minimum } \\
\text { detected } \\
\text { concen- } \\
\text { tration }\end{array}$ & $\begin{array}{c}\text { Minimum } \\
\text { reporting } \\
\text { level }\end{array}$ & $\begin{array}{c}\text { Maxi- } \\
\text { mum } \\
\text { contam- } \\
\text { inant } \\
\text { level }\end{array}$ & $\begin{array}{c}\text { Lifetime } \\
\text { health } \\
\text { advisory } \\
\text { level }\end{array}$ \\
\hline & & & & \multicolumn{5}{|c|}{ (micrograms per liter) } \\
\hline Atrazine & AAtrex & restricted use herbicide & 23 & 1.58 & E 0.004 & 0.001 & 3 & - \\
\hline Deethylatrazine & DEA, Desethylatrazine & degradation product of atrazine & 21 & E. 320 & E.004 & .002 & - & - \\
\hline Deethyldeisopropylatrazine & DEIA & degradation product of atrazine & 19 & E.12 & E.01 & .06 & - & - \\
\hline Deisopropylatrazine & - & $\begin{array}{l}\text { degradation product of atrazine } \\
\text { and simazine }\end{array}$ & 4 & E. 02 & E.01 & .07 & - & - \\
\hline 2-Hydroxyatrazine & - & degradation product of atrazine & 10 & E. 511 & E.044 & .193 & - & - \\
\hline Bromocil & Hyvar, Urox B & general use herbicide & 1 & .19 & - & .081 & - & 90 \\
\hline Caffeine & - & $\begin{array}{l}\text { occurs naturally in tea, coffee, } \\
\text { and cola nuts }\end{array}$ & 2 & Е.029 & E.011 & .081 & - & - \\
\hline Cycloate $^{1}$ & Ro-Neet & herbicide & 4 & E.04 & E.03 & .05 & - & - \\
\hline Diazinon & $\mathrm{D}-\mathrm{Z}-\mathrm{N}$ & restricted use insecticide & 1 & E.002 & - & .002 & - & .6 \\
\hline Diuron & Karmex, Direx & general use herbicide & 1 & .32 & - & .08 & - & 10 \\
\hline Imazaquin $^{1}$ & Ala-Scept, Scepter & general use herbicide & 2 & E.006 & E.006 & .103 & - & - \\
\hline Malathion & Cythion & general use insecticide & 1 & .006 & - & .005 & - & 100 \\
\hline $\mathrm{P}, \mathrm{P}^{\prime} \mathrm{DDE}$ & - & degradation product of DDT & 1 & E.002 & - & .006 & - & - \\
\hline Picloram & Access, Tordon & restricted use herbicide & 1 & .47 & - & .07 & 500 & 500 \\
\hline Prometon & Pramitol & general use herbicide & 15 & .518 & E.004 & .018 & - & 100 \\
\hline Simazine & Aquazine, Princep & restricted use herbicide & 13 & .027 & E.004 & .005 & 4 & 4 \\
\hline Tebuthiuron & Brush, Spike, Perflan & restricted use herbicide & 4 & .120 & E.012 & .010 & - & 500 \\
\hline
\end{tabular}


Table 4. Concentration and detection frequency of volatile organic compounds detected in water sampled from 30 monitoring wells in areas of recent residential development, Salt Lake Valley, Utah

[Maximum contaminant level is the U.S. Environmental Protection Agency established drinking-water standard (U.S. Environmental Protection Agency, 2002). Lifetime health advisory level is defined as the concentration of a chemical in drinking water that is not expected to cause any adverse noncarcinogenic effects for a lifetime of exposure (U.S. Environmental Protection Agency, 2002). E, estimated value; M, presence of compound verified but not quantified; -, not applicable or no standard]

\begin{tabular}{|c|c|c|c|c|c|c|c|c|}
\hline \multirow[t]{2}{*}{ Volatile organic compound } & \multirow[t]{2}{*}{$\begin{array}{l}\text { Alternative name or } \\
\text { abbreviation }\end{array}$} & \multirow[t]{2}{*}{ Predominant use } & \multirow[t]{2}{*}{$\begin{array}{l}\text { Number of } \\
\text { detections }\end{array}$} & $\begin{array}{c}\text { Maximum } \\
\text { concen- } \\
\text { tration }\end{array}$ & $\begin{array}{c}\text { Minimum } \\
\text { detected } \\
\text { concen- } \\
\text { tration }\end{array}$ & $\begin{array}{l}\text { Laboratory } \\
\text { reporting } \\
\text { level }\end{array}$ & $\begin{array}{c}\text { Maximum } \\
\text { contami- } \\
\text { nant } \\
\text { level }\end{array}$ & $\begin{array}{c}\text { Lifetime } \\
\text { health } \\
\text { advisory } \\
\text { level }\end{array}$ \\
\hline & & & & \multicolumn{5}{|c|}{ (micrograms per liter) } \\
\hline Benzene $^{1}$ & - & fuel-related compound & 2 & E 0.01 & $\mathrm{M}$ & 0.04 & 5 & - \\
\hline Bromodichloromethane $^{2}$ & Dichlorobromomethane & chlorination byproduct & 17 & .51 & E.02 & .05 & 80 & - \\
\hline Carbon disulfide & - & naturally occurring & 3 & E.10 & E.01 & .07 & - & - \\
\hline Chloroform $^{2}$ & Trichloromethane & $\begin{array}{l}\text { solvent, chlorination } \\
\text { byproduct }\end{array}$ & 27 & 2.41 & E.03 & .05 & 80 & - \\
\hline Chloromethane & Methyl chloride & solvent & 1 & E.1 & - & .5 & - & 30 \\
\hline 1,1-Dichloroethane & Ethylidine chloride & solvent & 1 & E.03 & - & .07 & - & - \\
\hline 1,2-Dichloroethane & Ethylene dichloride & metal degreaser & 1 & .4 & - & .1 & 5 & - \\
\hline 1,1-Dichloroethylene & $1,1-\mathrm{DCE}$ & organic synthesis & 2 & E.05 & E.01 & .04 & 7 & 6 \\
\hline Dichloromethane & Methylene chloride & solvent, metal degreaser & 6 & E. 3 & M & .4 & 5 & - \\
\hline Ethylbenzene ${ }^{1}$ & Ethylbenzol & fuel-related compound & 2 & E.02 & E.01 & .03 & 700 & 700 \\
\hline o-Ethyl toluene ${ }^{1}$ & - & fuel-related compound & 1 & E.01 & - & .06 & - & - \\
\hline Methyl tert-butyl ether & MTBE & fuel oxygenate & 1 & E.1 & - & .2 & - & - \\
\hline Tetrachloroethylene & Tetrachloroethene, PCE & solvent & 16 & 7.8 & M & .1 & 5 & 10 \\
\hline Tetrachloromethane & Carbon tetrachloride & solvent, metal degreaser & 1 & E. .01 & - & .06 & 5 & - \\
\hline Toluene $^{1}$ & Methylbenzene & fuel-related compound & 2 & E.01 & E.01 & .05 & 1,000 & 1,000 \\
\hline 1,1,1-Trichloroethane & Methyl chloroform, TCA & solvent & 15 & .22 & E.01 & .03 & 200 & 200 \\
\hline Trichloroethylene & Trichloroethene, TCE & solvent & 5 & 1.54 & E.02 & .04 & 5 & - \\
\hline Trichlorofluoromethane & Freon 11, CFC-11 & refrigerant, aerosol propellant & 2 & E.09 & E.04 & .09 & - & 2,000 \\
\hline $\begin{array}{l}\text { 1,1,2- } \\
\text { Trichlorotrifluoroethane }\end{array}$ & CFC-113 & refrigerant, aerosol propellant & 1 & E. 08 & - & .06 & - & - \\
\hline $1,2,3$-Trimethylbenzene ${ }^{1}$ & - & fuel-related compound & 1 & M & - & .1 & - & - \\
\hline $1,2,4$-Trimethylbenzene ${ }^{1}$ & Psuedocumene & fuel-related compound & 2 & E.03 & E.01 & .06 & - & - \\
\hline $1,3,5$-Trimethylbenzene ${ }^{1}$ & - & fuel-related compound & 1 & E. 01 & - & .04 & - & - \\
\hline $\mathrm{m}$ - and $\mathrm{p}-\mathrm{Xylene} \mathrm{e}^{1}$ & $\begin{array}{l}\text { 1,3+1,4- } \\
\text { Dimethylbenzene }\end{array}$ & fuel-related compound & 4 & E.08 & E.01 & .06 & ${ }^{3} 10,000$ & ${ }^{3} 10,000$ \\
\hline o-Xylene ${ }^{1}$ & 1,2-Dimethylbenzene & fuel-related compound & 1 & E.02 & - & .04 & ${ }^{3} 10,000$ & ${ }^{3} 10,000$ \\
\hline
\end{tabular}

${ }^{1}$ Presence in the ground-water and (or) field-blank samples may be the result of contamination in the field while sampling.

${ }^{2}$ A trihalomethane, it is a byproduct of the chlorination disinfection process. The maximum contaminant level for total trihalomethanes is 80 micrograms per liter.

${ }^{3}$ Maximum contaminant level and lifetime health advisory level are for total xylene. 


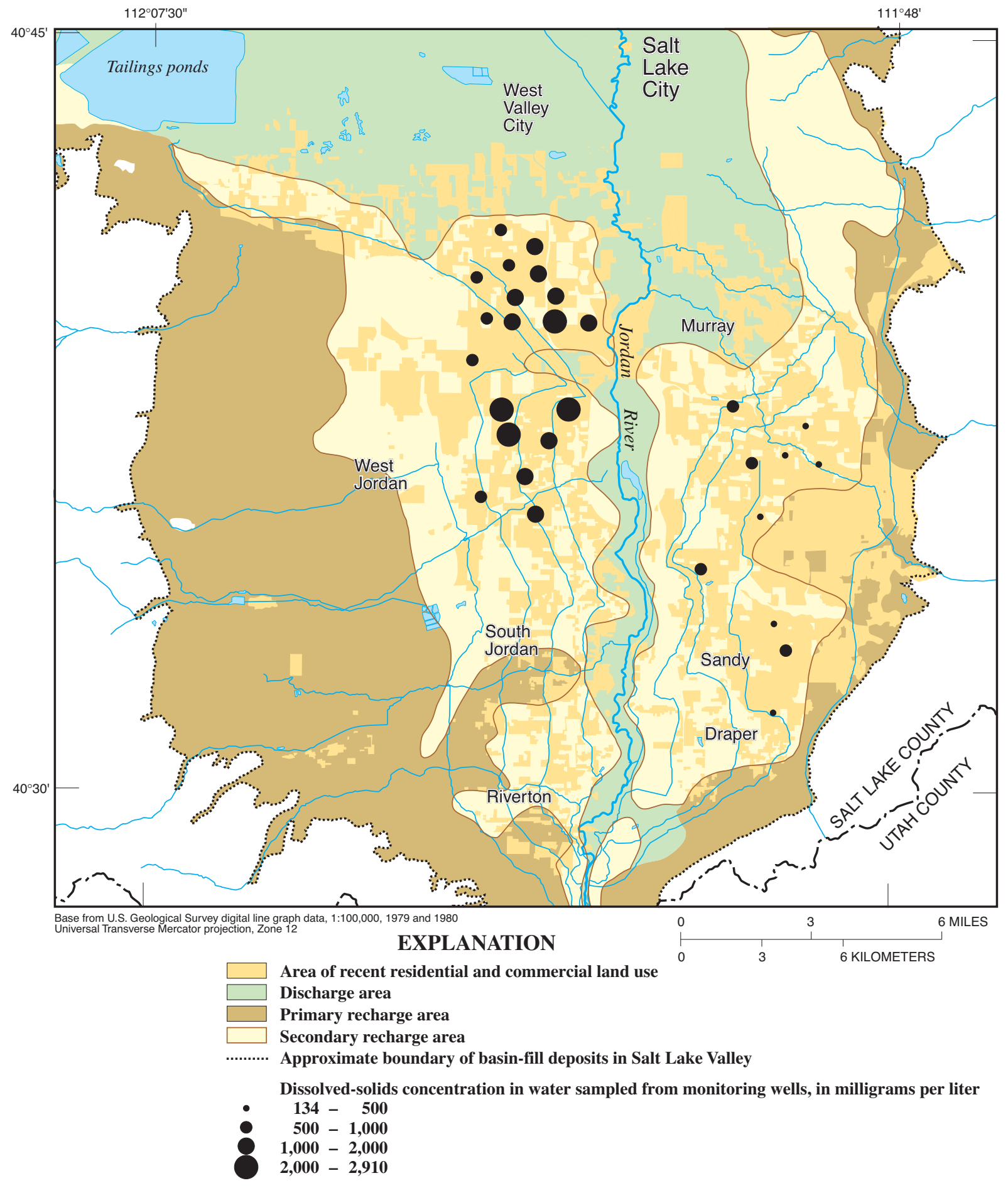

Figure 6. Dissolved-solids concentration in water sampled from monitoring wells in areas of recent residential development, Salt Lake Valley, Utah. 
The secondary drinking-water regulation for sulfate $(250 \mathrm{mg} / \mathrm{L})$ (U.S. Environmental Protection Agency, 2002) was exceeded in water from 11 wells on the west side of the valley. Sulfate is the predominant anion in water from monitoring wells 17, 20, 24, 25, and 33 located south of 6200 South Street on the west side. Sulfate dissolved in ground water in the area may result from dissolution of gypsum or oxidation of pyrite and other sulfide minerals. A sand and gravel spit extends from the mountain front eastward into the valley at about 6200 South Street, formed by southflowing Lake Bonneville currents that deposited sediment from the north end of the Oquirrh Mountains. Sediment from streams draining sulfide-mineralized rocks in the Bingham Canyon area could have been deposited behind the spit in a lower energy environment, such as a lagoon. Little natural recharge occurs in this area other than from infiltration of precipitation because the mountain-front streams are ephemeral. Oxidized water recharged from local precipitation and the canals could react with the sulfide-rich aquifer material and result in dissolved sulfate. The primary cation in water from most wells in the area is sodium rather than calcium, indicating that gypsum dissolution may not be the source of sulfate.

Chloride concentrations in water from the monitoring wells ranged from 13 to $456 \mathrm{mg} / \mathrm{L}$ and were highest in water from wells $2,4,6$, and 10 in the northwestern part of the valley (table 7 , appendix). The secondary drinking-water regulation of $250 \mathrm{mg} / \mathrm{L}$ for chloride (U.S. Environmental Protection Agency, 2002) was exceeded in water from 10 wells, all located on the west side of the valley. Water from the Utah and Salt Lake Canal (USGS site number 403524111572202) had a dissolved-solids concentration of $832 \mathrm{mg} / \mathrm{L}, 203 \mathrm{mg} / \mathrm{L}$ of which was chloride. Monitoring wells 2 and 4 are located near faults (fig. 1) and contained water with more than twice as much chloride as did water from the canal. Water movement along a fault may affect water quality in the area.

The inorganic chemical composition of ground water largely depends on the type of rocks and associated minerals with which it has been in contact. Basin-fill deposits in the southeastern part of the valley are derived from rocks more resistant to weathering, such as quartzite and quartz monzonite. Shallow ground water from the monitoring wells on the east side of Salt Lake Valley is predominantly a calcium bicarbonate type that indicates less reactive aquifer material that contains quartz (fig. 7).

Basin-fill deposits on the west side of the valley have eroded from more varied rock sources. The Oquirrh Mountains are composed of Paleozoic carbonate rocks, some of which have undergone sulfide mineralization; Tertiary volcanic rocks; and Quaternary to Tertiary semiconsolidated alluvial deposits. Sodium, calcium, bicarbonate, and chloride are the predominant ions in water from monitoring wells 8,14 , and 31 .

These are the westernmost monitoring wells upgradient from all or most of the canals, and the chemical composition of the ground water is likely controlled by reaction with the aquifer material. The predominant ions in water from wells completed in the deeper aquifer in the area are calcium, chloride, and bicarbonate, indicating that water at greater depths has undergone similar reactions with the aquifer material.

Seepage from four irrigation canals that divert water from the Jordan River is a major source of recharge on the west side of the valley, in addition to recharge from locally derived precipitation. The Jordan River drains Utah Lake, which becomes more mineralized by mixing with geothermal water, dissolution, and evaporation. Predominant ions in water from the Utah and Salt Lake Canal near monitoring well 33 are sodium and chloride. Wells downgradient from the canals north of 6200 South Street contain water that ranges from a sodium bicarbonate type to a sodium chloride type and is likely a mixture of locally recharged water and seepage from the canals.

\section{Trace Elements}

Concentrations of the trace elements nickel, selenium, antimony, chromium, and barium, analyzed for in water from the monitoring wells, were less than the MCLs or HALs. Lead, silver, cadmium, and beryllium were analyzed for, but not detected. Molybdenum, arsenic, uranium, and radon were detected in water from some wells at concentrations that exceeded MCLs, proposed MCLs, or HALs. The lifetime HAL of $40 \mu \mathrm{g} / \mathrm{L}$ for molybdenum (U.S. Environmental Protection Agency, 2002) was exceeded in water from four monitoring wells (wells 2, 9, 17, and 29) (table 8, appendix). 


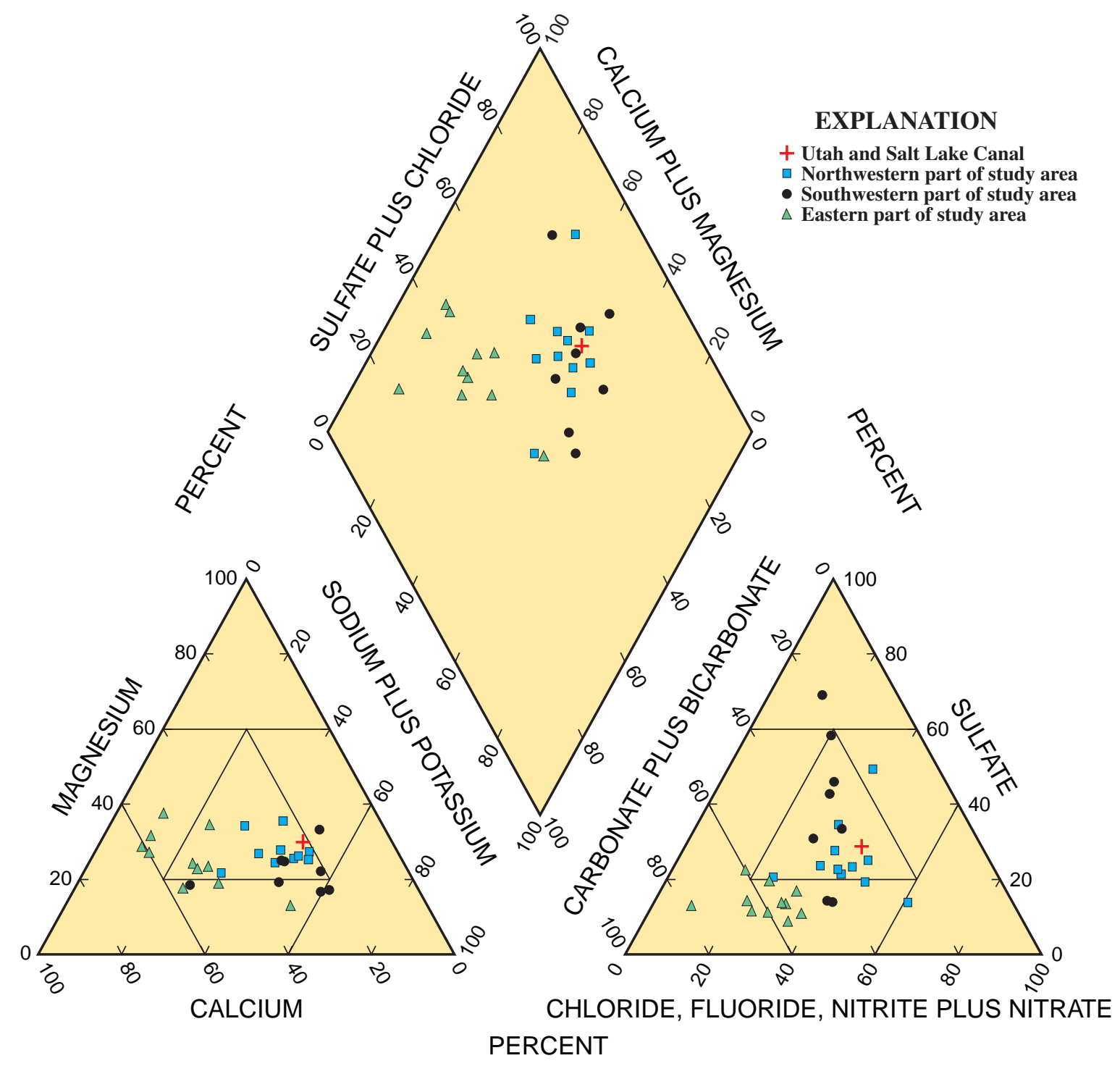

Figure 7. Major-ion composition of water sampled from monitoring wells in areas of recent residential development, Salt Lake Valley, Utah. 
Arsenic concentrations ranged from less than 1 $\mu \mathrm{g} / \mathrm{L}$ in ground water from the east side of Salt Lake Valley to almost $20 \mu \mathrm{g} / \mathrm{L}$ in ground water from the west side (fig. 8). The median concentration for water from the 30 monitoring wells was $7 \mu \mathrm{g} / \mathrm{L}(1.1 \mu \mathrm{g} / \mathrm{L}$ for the east side of the valley and $11.7 \mu \mathrm{g} / \mathrm{L}$ for the west side). Concentrations in water from 12 wells, all of which are on the west side of the valley, exceeded the drinking water MCL of $10 \mu \mathrm{g} / \mathrm{L}$ (U.S. Environmental Protection Agency, 2002).

Water from monitoring wells in the northwestern part of the valley generally had higher arsenic concentrations than other areas (fig. 8). This may be related to more fine-grained deposits, and therefore a greater likelihood for reducing conditions, coupled with less recharge available to move arsenic through the system. The proximity of faults, and the potential for geothermal water to move into the basin-fill deposits, is also a potential factor for elevated arsenic concentrations in the area. Arsenic is present in volcanic gases and is a common constituent of geothermal water (Hem, 1989, p. 144).

Water in the Utah and Salt Lake Canal, a source of recharge to the west side of the valley, had $10 \mu \mathrm{g} / \mathrm{L}$ of dissolved arsenic. Iron oxide that adsorbs or contains arsenic can be dissolved or reduced through the addition of organic carbon, resulting in release of arsenic to the ground water (Welch and others, 2000; Welch and Lico, 1998). Reddish-orange and black staining on sediment particles indicate iron oxide and manganese oxide coatings, respectively, and were noted in the unsaturated zone while drilling many of the west-side monitoring wells. The relatively high arsenic concentration and the presence of dissolved iron $(40 \mu \mathrm{g} / \mathrm{L})$ and organic carbon $(3.2 \mathrm{mg} / \mathrm{L})$ in water from well 4 may indicate this process.

Tertiary-age volcanic rocks and the Salt Lake Formation exposed near the base of the Oquirrh Mountains may be a source of arsenic that is not present on the east side of the valley. The Oquirrh Mountains consist mainly of Paleozoic-age carbonate and quartzite rocks that were intruded by mid-Tertiaryage igneous rocks and associated mineralized fluids in the Bingham Canyon area. Basin-fill deposits derived from the sulfide mineralized consolidated rocks contain arsenic. Oxidation of arsenic-bearing sulfides also can release arsenic to ground water. Water from well 20 had relatively high concentrations of dissolved arsenic $(17.7 \mu \mathrm{g} / \mathrm{L})$ and sulfate $(1,480 \mathrm{mg} / \mathrm{L})$, possibly as a result of sulfide oxidation.
Ground water affected by mining activities of sulfide-ore deposits near Bingham Creek had a mean arsenic concentration of $14 \mu \mathrm{g} / \mathrm{L}$ (Kennecott Utah Copper Environmental Engineering Projects Group, written commun., 1998, table 4.9). The processed ore is transported to a smelter at the north end of the Oquirrh Mountains that may release arsenic to the air and affect concentrations in local precipitation. Arsenic concentrations averaging $17 \mu \mathrm{g} / \mathrm{L}$ were measured in rain and snow collected downwind from a smelter in Tacoma, Washington (Crecelius, 1975). Sediment cored from Mirror Lake, in the Uinta Mountains about $50 \mathrm{mi}$ east of Salt Lake City, was enriched in arsenic, lead, zinc, copper, tin, and cadmium relative to deeper sediments (Kada and others, 1994). The start of largescale mining and smelting of nonferrous metal ores in the Salt Lake Valley area corresponds with the increase of arsenic in the dated lake sediment.

\section{Radionuclides}

Radon occurs naturally as a gas that is soluble in ground water and is released through radioactive decay from rocks containing uranium (fig. 9). It is the direct result of decay of radium-226, a decay product of uranium-238. Higher concentrations of radon occur in areas with uranium-rich sources such as granite, metamorphic rocks, and basin-fill deposits weathered from these rocks. Because of a short half-life of 3.8 days, radon is detected near its source. The radon concentration in water is reported in terms of activity where $1 \mathrm{pCi} / \mathrm{L}$ is about equal to the decay of two atoms of radon per minute in a liter of water. Radon moves more easily through highly permeable material, such as sand, gravel, and fractures, and readily degasses from water exposed to air. Breathing radon in indoor air is the second leading cause of lung cancer and is a greater health concern than drinking water that contains radon (U.S. Environmental Protection Agency, 1999). The proposed MCL for radon in drinking water is 300 pCi/L (U.S. Environmental Protection Agency, 2002).

Radon concentrations in water from the 30 monitoring wells ranged from 243 to $2,190 \mathrm{pCi} / \mathrm{L}$, with a median value of $574 \mathrm{pCi} / \mathrm{L}$ (table 2). Only water from wells 3 and 11, in the northwestern part of the valley, had a concentration of less than $300 \mathrm{pCi} / \mathrm{L}$. The median concentration for water from monitoring wells on the east side of the valley was $719 \mathrm{pCi} / \mathrm{L}$ compared to 524 $\mathrm{pCi} / \mathrm{L}$ on the west side. Water from wells $22,32,37$, and 41 had radon concentrations greater than 1,000 


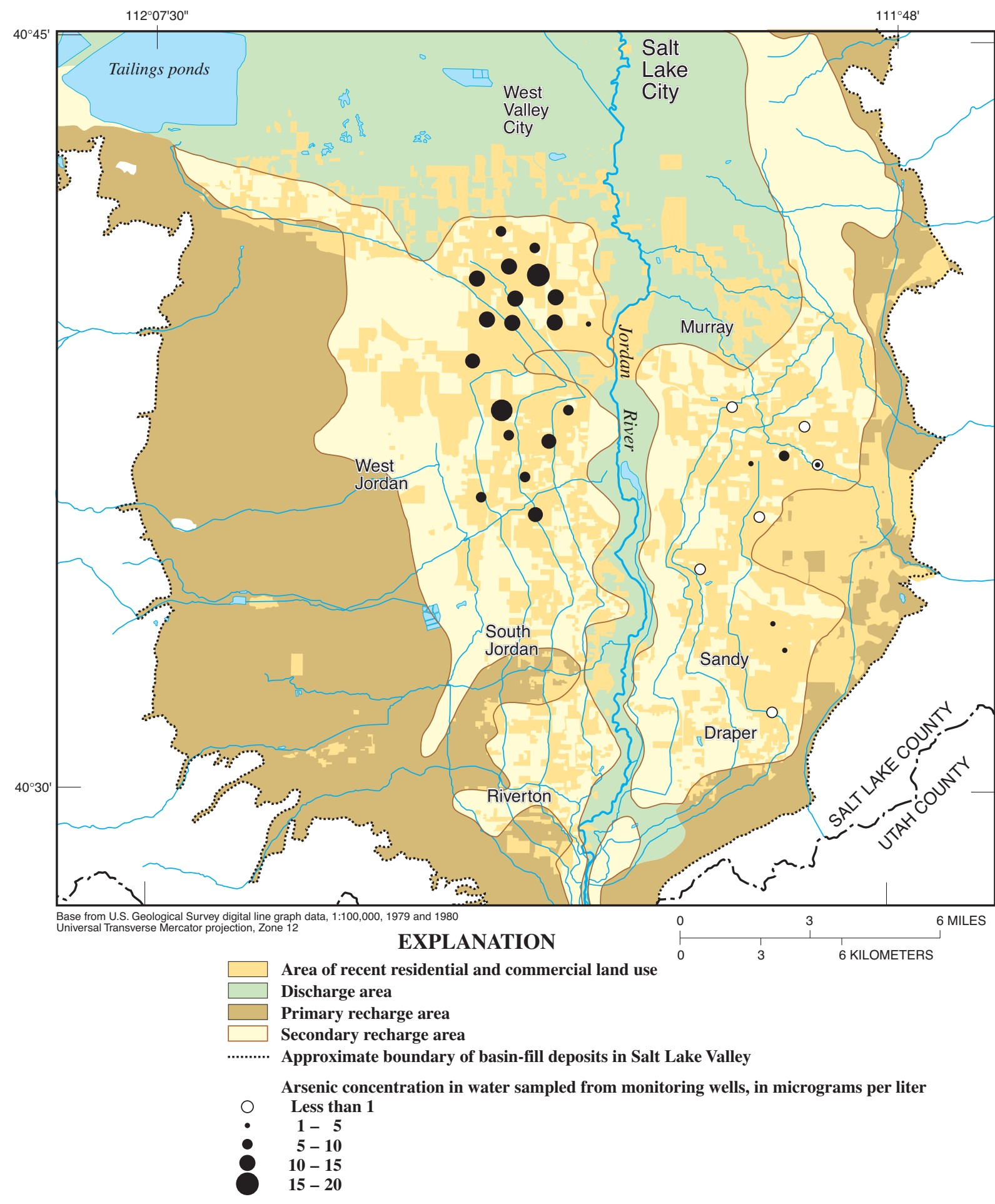

Figure 8. Arsenic concentration in water sampled from monitoring wells in areas of recent residential development, Salt Lake Valley, Utah. 


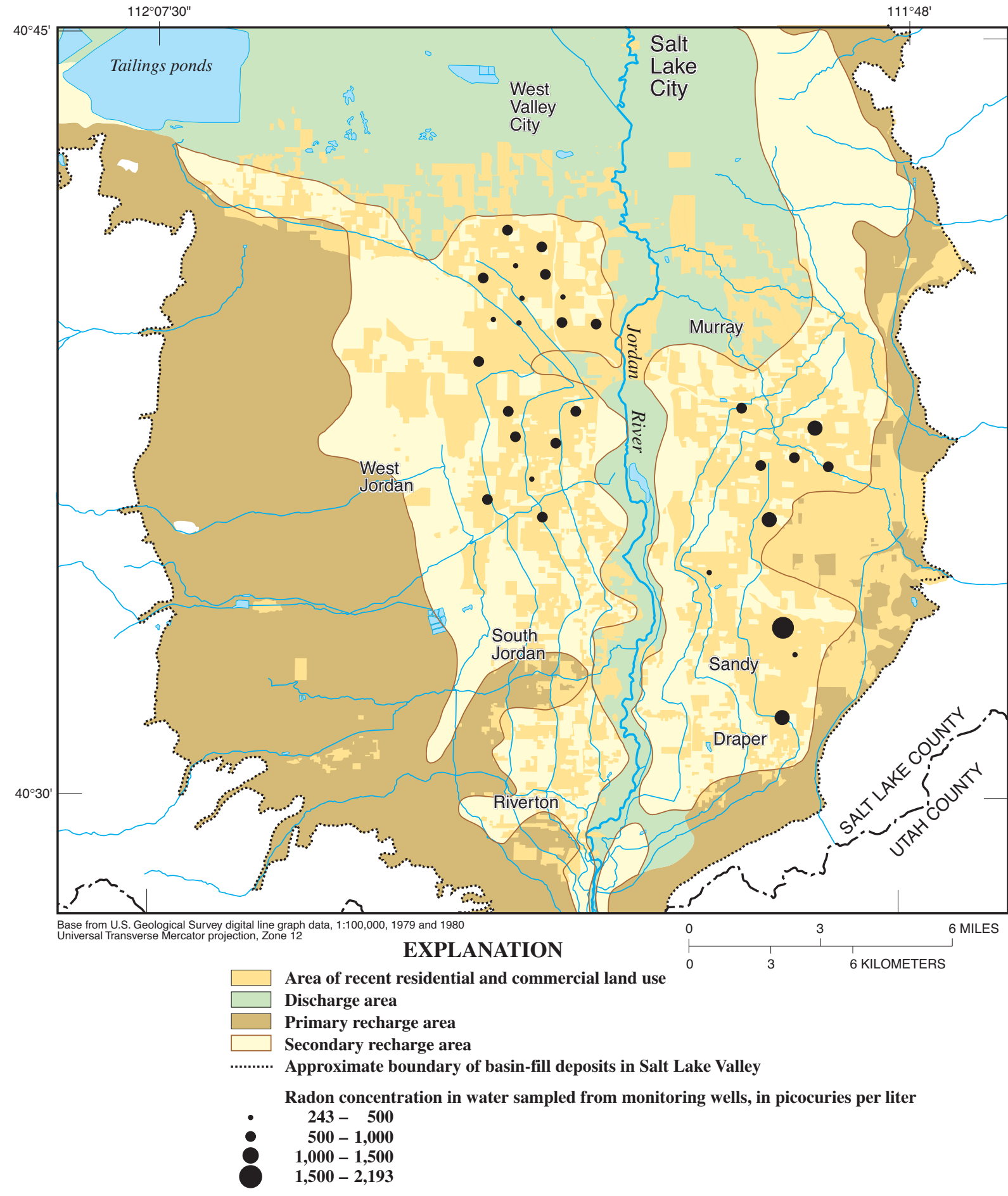

Figure 9. Radon concentration in water sampled from monitoring wells in areas of recent residential development, Salt Lake Valley, Utah. 
$\mathrm{pCi} / \mathrm{L}$. These wells are located on the east side of valley where the mountain block is composed of quartzite and quartz monzonite.

Uranium dissolved in water from the monitoring wells ranged from less than $1 \mu \mathrm{g} / \mathrm{L}$ at well 29 to about $93 \mu \mathrm{g} / \mathrm{L}$ at well 41 , both on the east side of the valley (table 8). Uranium is soluble under oxidizing conditions, and because of its long half-life $\left(4.5 \times 10^{9}\right.$ years) can be transported by ground water farther from its source areas than can radon. It is concentrated in the sediment in reducing environments because of mineral precipitation. The lack of detectable uranium in water from well 29 is a result of reducing conditions. The relatively high uranium concentration in water from well 41 may result from its proximity to intrusive rocks in the Wasatch Range. The MCL for uranium of 30 $\mu \mathrm{g} / \mathrm{L}$ (U.S. Environmental Protection Agency, 2002) was exceeded in water from three wells, all of which are on the east side of Salt Lake Valley.

\section{Nutrients and Dissolved Organic Carbon}

Although the nutrients nitrogen and phosphorus can occur naturally in ground water, elevated concentrations in ground water are thought to be caused by human activities. Some of the potential sources of nutrients in ground water include fertilizers applied to lawns and gardens and leaking or improperly functioning septic systems and sewer pipes. Nitrogen compounds such as ammonia and ammonium fertilizers naturally transform into nitrate, which is relatively stable in oxygenated subsurface environments and is readily transported in water. Nitrite is unstable in aerated water and is seldom present in measurable concentrations under oxidizing conditions. In this report, nitrate is reported as the sum of nitrite and nitrate as nitrogen.

Background nitrate concentrations in ground water from areas not associated with agricultural practices commonly are less than 2 to $3 \mathrm{mg} / \mathrm{L}$ as nitrogen (Halberg and Keeney, 1993) and concentrations greater than $2 \mathrm{mg} / \mathrm{L}$ may indicate ground water affected by human activities (U.S. Geological Survey, 1999). Some existing nitrate data for ground water in the Great Salt Lake Basins study area are available from the USGS National Water Information System (NWIS) database. In urban/residential areas, the median nitrate concentration in water from wells less than $150 \mathrm{ft}$ deep was $1.1 \mathrm{mg} / \mathrm{L}$ (71 analyses); in water from wells greater than $150 \mathrm{ft}$ deep, generally completed in the deeper unconfined aquifers, it was less than $1 \mathrm{mg} / \mathrm{L}$ (110 analyses).

Nitrate concentration in water sampled from 26 of the 30 monitoring wells ( 86.7 percent) was higher than an assumed background level of $2 \mathrm{mg} / \mathrm{L}$, indicating a possible human influence. Concentrations ranged from less than 0.05 to $13.3 \mathrm{mg} / \mathrm{L}$ with a median concentration of $6.85 \mathrm{mg} / \mathrm{L}$ for the 30 samples (table 9 , appendix). The median nitrate concentration for water from monitoring wells on the east side of the valley was $4.45 \mathrm{mg} / \mathrm{L}$ compared to $7.05 \mathrm{mg} / \mathrm{L}$ on the west side (fig. 10). The MCL of $10 \mathrm{mg} / \mathrm{L}$ for nitrate in drinking water (U.S. Environmental Protection Agency, 2002) was exceeded in water from wells 11, 17, and 37.

Concentrations of nitrite, ammonia, ammonia plus organic nitrogen, phosphorus, and orthophosphorus in water from the monitoring wells were low, 2 to 3 orders of magnitude less than MCLs or health advisory levels. Nitrite was detected in water from 5 of the 30 wells, 3 of which had other indicators of reducing conditions. The presence of nitrite in water from four of the wells corresponded to nitrate concentrations greater than $7.5 \mathrm{mg} / \mathrm{L}$. Ammonia detected in seven ground-water samples may be the result of sample contamination because ground-water concentrations were only slightly greater than those measured in a field-blank sample. Water from four of the wells had phosphorus concentrations greater than $0.1 \mathrm{mg} / \mathrm{L}$, and two of those also had the highest nitrate concentrations (wells 17 and 37). Water from these wells likely has been affected by anthropogenic factors such as sewer lines, septic tanks, confined animals, or fertilizers.

DOC can affect ground-water quality because it is involved in oxidation/reduction reactions with chemical constituents of the aquifer material and ground water. The median DOC concentration in water from the monitoring wells was $1.5 \mathrm{mg} / \mathrm{L}$ and ranged from $0.60 \mathrm{mg} / \mathrm{L}$ at well $26 \mathrm{~S}$ to $4.6 \mathrm{mg} / \mathrm{L}$ at well 1 (table 9 , appendix). DOC measured in water from six fieldblank samples (median concentration of $0.96 \mathrm{mg} / \mathrm{L}$ ) is attributed to contamination introduced from the sampling equipment cleaning procedure. Rinsing of the sampling equipment with ground water during the purge cycle likely reduces DOC contamination, but some of the DOC measured in water from the wells may be from the sampling equipment. 


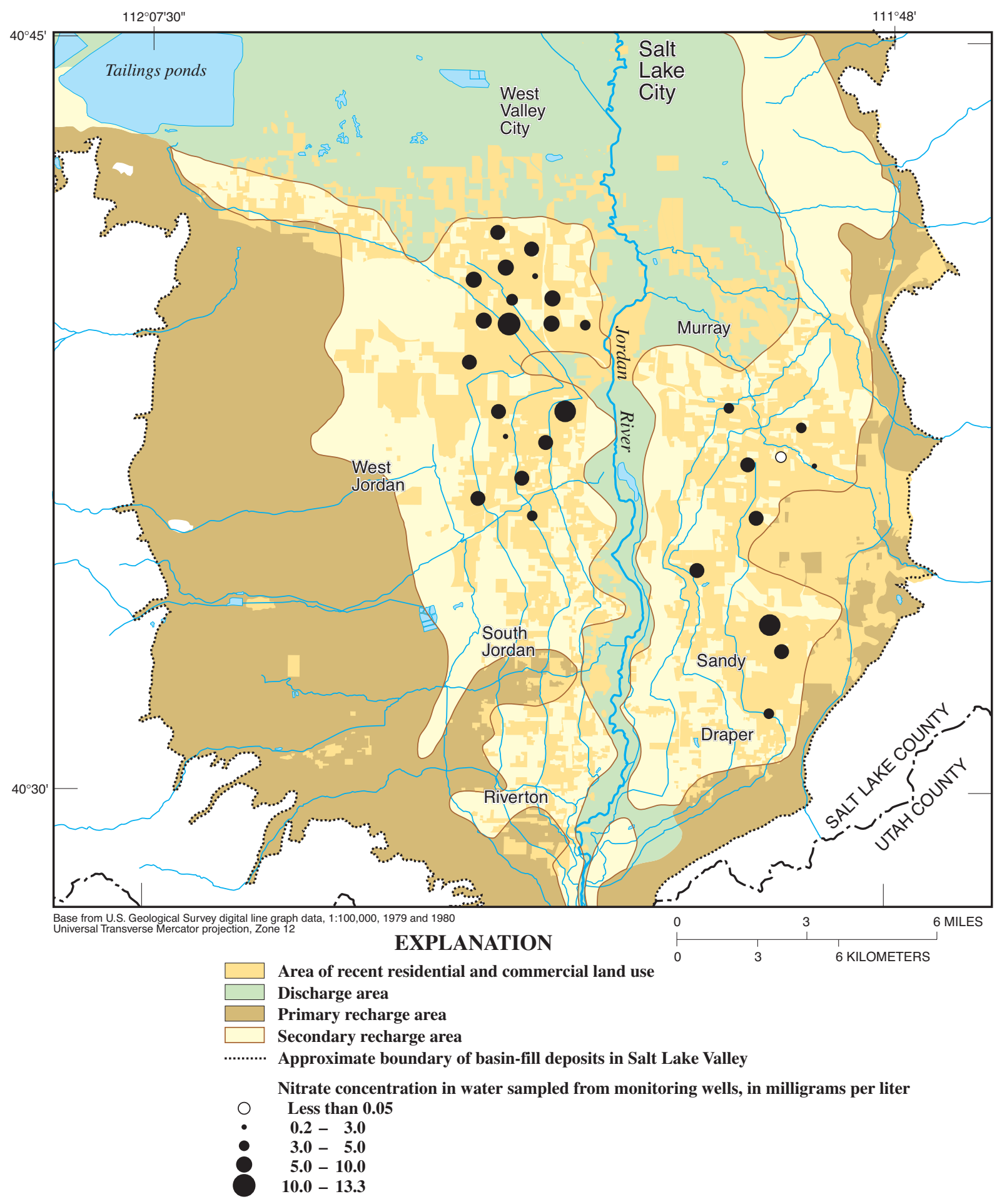

Figure 10. Nitrate concentration in water sampled from monitoring wells in areas of recent residential development, Salt Lake Valley, Utah. 


\section{Pesticides}

Fifteen of the 104 pesticides and pesticide degradation products analyzed for were detected in 1 or more water samples collected as part of this study (table 3 and fig. 11). Breakdown products of pesticides (metabolites or degradates) are formed through the metabolic degradation of a parent compound. All of the pesticides analyzed as part of this study are listed in table 10 (appendix). Most are used as herbicides. The insecticides diazinon and malathion were detected in trace amounts in one sample each. At least one pesticide or pesticide degradation product was detected in water from 28 of the 30 monitoring wells. The two wells with no pesticide detections are located on the east side of the valley (wells 32 and 37). Water from well 7 on the west side of the valley contained 10 different pesticide compounds, including bromacil, diuron, atrazine, and atrazine degradation products, all herbicides used to control roadside vegetation. No pesticides were detected at concentrations that exceeded USEPA drinking-water standards or guidelines (U.S. Environmental Protection Agency, 2002).

Much lower analytical reporting levels were used in this study than are typically used in routine pesticide monitoring of public-water supplies. Therefore, much higher rates of detection were obtained than would have been possible with less sensitive analytical methods. The MRL for atrazine is $0.001 \mu \mathrm{g} / \mathrm{L}$, about

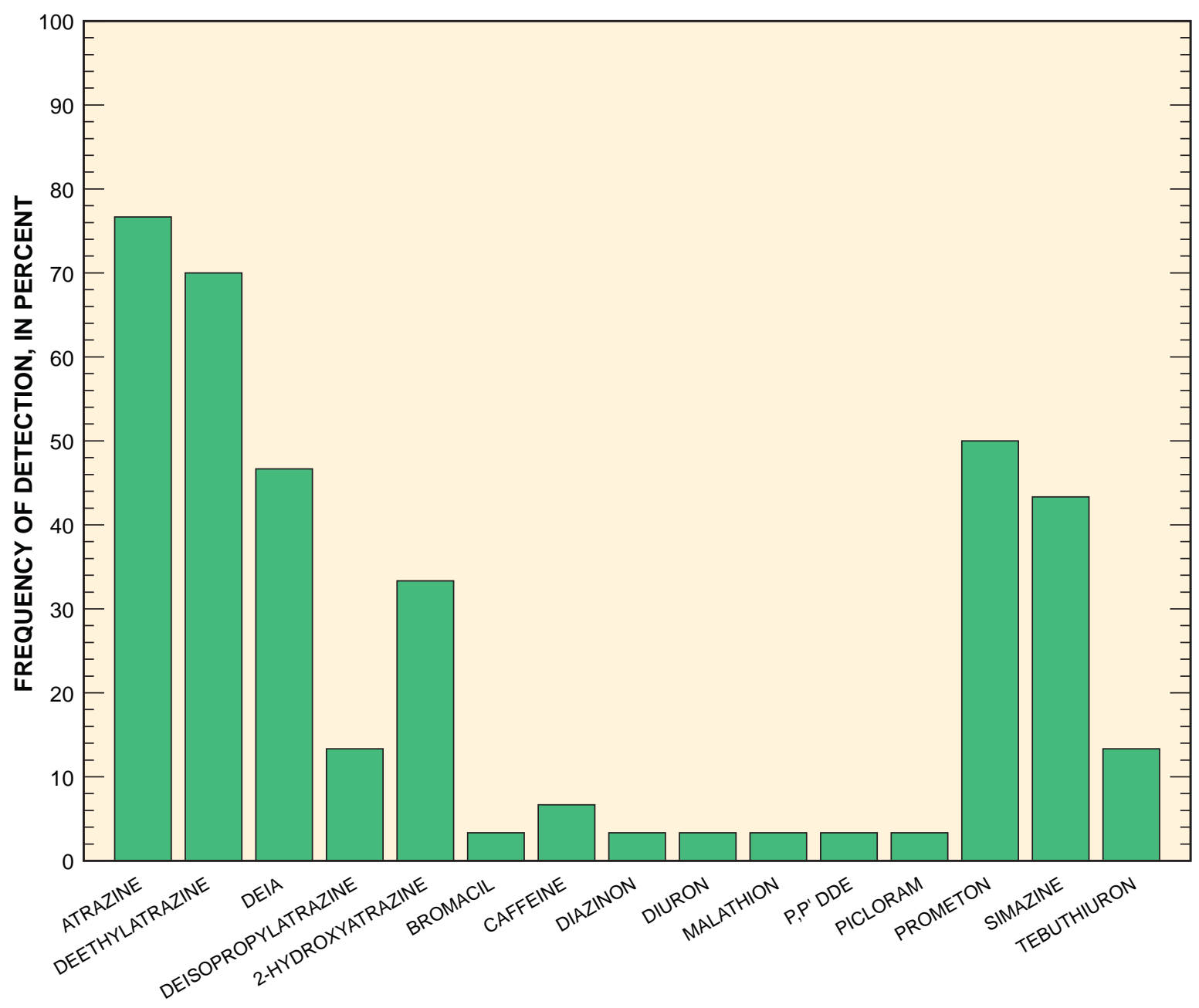

Figure 11. Detection frequency of pesticides in water sampled from monitoring wells in areas of recent residential development, Salt Lake Valley, Utah. 
two orders of magnitude lower than that used on water from drinking-water wells for the USEPA's National Pesticide Survey done in 1988-90 (Barbash and others, 1999).

Water-quality standards are based on concentrations of individual pesticides and do not account for mixtures of pesticides. Total concentration of pesticides and pesticide degradation products in water ranged from an estimated $0.002 \mu \mathrm{g} / \mathrm{L}$ at well 22 (diazinon) to $2.56 \mu \mathrm{g} / \mathrm{L}$ at well 11 (a mixture of atrazine, atrazine degradation products, and simazine). The effects of different combinations of pesticides on human health are not known at this time; therefore, drinking-water standards have not been set for pesticide mixtures.
The herbicide atrazine and its degradation product deethylatrazine (DEA) were the most frequently detected pesticides in the study, detected in 23 and 21 of the 30 water samples, respectively. All but one of the water samples from the west side of the valley contained detectable concentrations of atrazine (well 14). Atrazine concentrations in water from the 30 monitoring wells ranged from less than 0.001 to 1.58 $\mu \mathrm{g} / \mathrm{L}$ (table 11, appendix), all below the MCL for atrazine in drinking water of $3 \mu \mathrm{g} / \mathrm{L}$ (U.S.

Environmental Protection Agency, 2002) (fig. 12).

Atrazine is a restricted-use pesticide that is generally used on corn and along roads, railroads, other right-of-ways, utility substations, and industrial lots to control weeds and undesired vegetation in the valley (Mark Quilter, Utah Department of Agriculture and

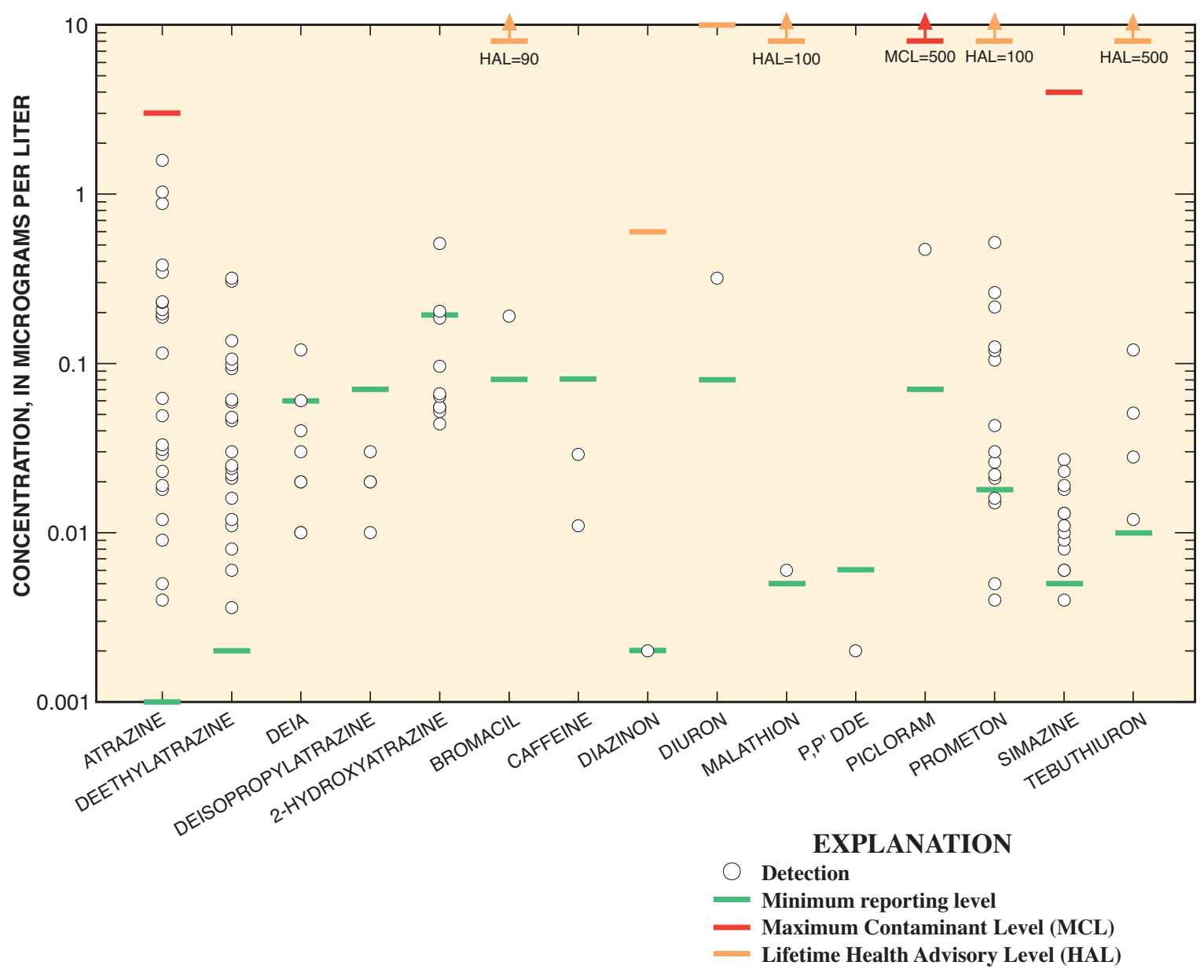

Figure 12. Concentration of selected pesticides in water sampled from monitoring wells in areas of recent residential development, Salt Lake Valley, Utah. 
Food, oral commun., 2000). It is not for household use. The high detection frequency of atrazine in residential areas on the west side may be the result of application in agricultural or industrial areas that have been converted to residential uses or application in areas upgradient from the residential areas that was then transported by ground water. The presence of atrazine and other pesticides in ground water is likely the result of widespread use rather than small-scale point sources such as spills. Atrazine probably is transported to the ground-water system by direct sources of recharge, such as seepage from drainage systems and retention basins.

Degradation products of atrazine other than DEA that were detected include deisopropylatrazine, deethyldeisopropylatrazine (DEIA), and 2hydroxyatrazine. Deisopropylatrazine can form from the degradation of either atrazine or simazine. The total concentration of atrazine and its degradation products in the 30 water samples ranged from not detected at six wells on the east side of the valley to $2.54 \mu \mathrm{g} / \mathrm{L}$ at well 11 on the west side (fig. 13). At least one of these compounds was detected in water from all 19 wells located on the west side of Salt Lake Valley. None of the cumulative concentrations of atrazine and its degradation products were greater than $0.1 \mu \mathrm{g} / \mathrm{L}$ in water sampled from the east side of the valley, whereas 12 of the samples from the west side contained more than $0.1 \mu \mathrm{g} / \mathrm{L}$.

Prometon was the third most frequently detected pesticide, detected in water sampled from 15 wells (50 percent), including 6 of the 11 samples collected from wells on the east side of the valley (fig. 14). The maximum concentration of $0.518 \mu \mathrm{g} / \mathrm{L}$ in water from well 1 is much less than the HAL for drinking water of $100 \mu \mathrm{g} / \mathrm{L}$ (U.S. Environmental Protection Agency, 2002). Prometon is registered for use by homeowners to control vegetation and generally is used along rightsof-way (Mark Quilter, Utah Department of Agriculture and Food, oral commun., 2000). It also can be used in and under asphalt to prevent weeds from emerging through it (Ciba-Geigy Corporation, 1994). Nationally, it was the most frequently detected herbicide in ground water at urban sites sampled as part of the NAWQA program (Capel and others, 1999). Its more frequent occurrence on the east side of the valley relative to atrazine and simazine may reflect greater usage in residential areas.
Simazine was detected in water sampled from 13 wells (43.3 percent) with a maximum concentration of $0.027 \mu \mathrm{g} / \mathrm{L}$ in well 1 , well below the MCL of $4 \mu \mathrm{g} / \mathrm{L}$ (U.S. Environmental Protection Agency, 2002). Simazine is commonly used as weed control for corn fields and orchards, on rights-of-way, and utility substations (Mark Quilter, Utah Department of Agriculture and Food, oral commun., 2000). All but one of the detections were in water from wells on the west side of the valley.

Tebuthiuron was detected in water sampled from 4 wells (13.3 percent) with a maximum concentration of $0.120 \mu \mathrm{g} / \mathrm{L}$ in water from well 2, far below the longterm HAL of $500 \mu \mathrm{g} / \mathrm{L}$ (U.S. Environmental Protection Agency, 2002). It is used along rights-of-way and to control sagebrush and weeds in noncrop areas of the valley (Mark Quilter, Utah Department of Agriculture and Food, oral commun., 2000). Tebuthiuron was detected in water from wells 18 and 41 on the east side of the valley in addition to prometon.

Concentrations of atrazine, simazine, prometon, malathion, and diazinon in water samples collected from Little Cottonwood Creek near the Jordan River in Salt Lake Valley increased during storm events (Gerner, 2003). Although this site is in a ground-water discharge area and is surrounded by more industrial land use than the residential study area, it indicates that pesticides can be concentrated in stormwater runoff. Runoff that flows to potential sources of recharge such as canals or retention basins in the primary or secondary recharge areas may also transport anthropogenic compounds that have been washed from the land surface to the shallow ground-water system.

\section{Volatile Organic Compounds}

VOCs are carbon-containing chemicals that readily evaporate at normal air temperature and pressure. They are contained in many manufactured products such as gasoline, paints, adhesives, solvents, wood preservatives, dry-cleaning agents, pesticides, fertilizers, cosmetics, and refrigerants. Potential sources of VOCs to ground water are direct industrial and wastewater discharges, infiltration of spills, leaking underground storage tanks, stormwater runoff, and atmospheric deposition of vehicle and industrial emissions. Many VOCs are used in and around the home and can enter the ground-water system through spills, storm drains, septic systems, and leaking sewer 


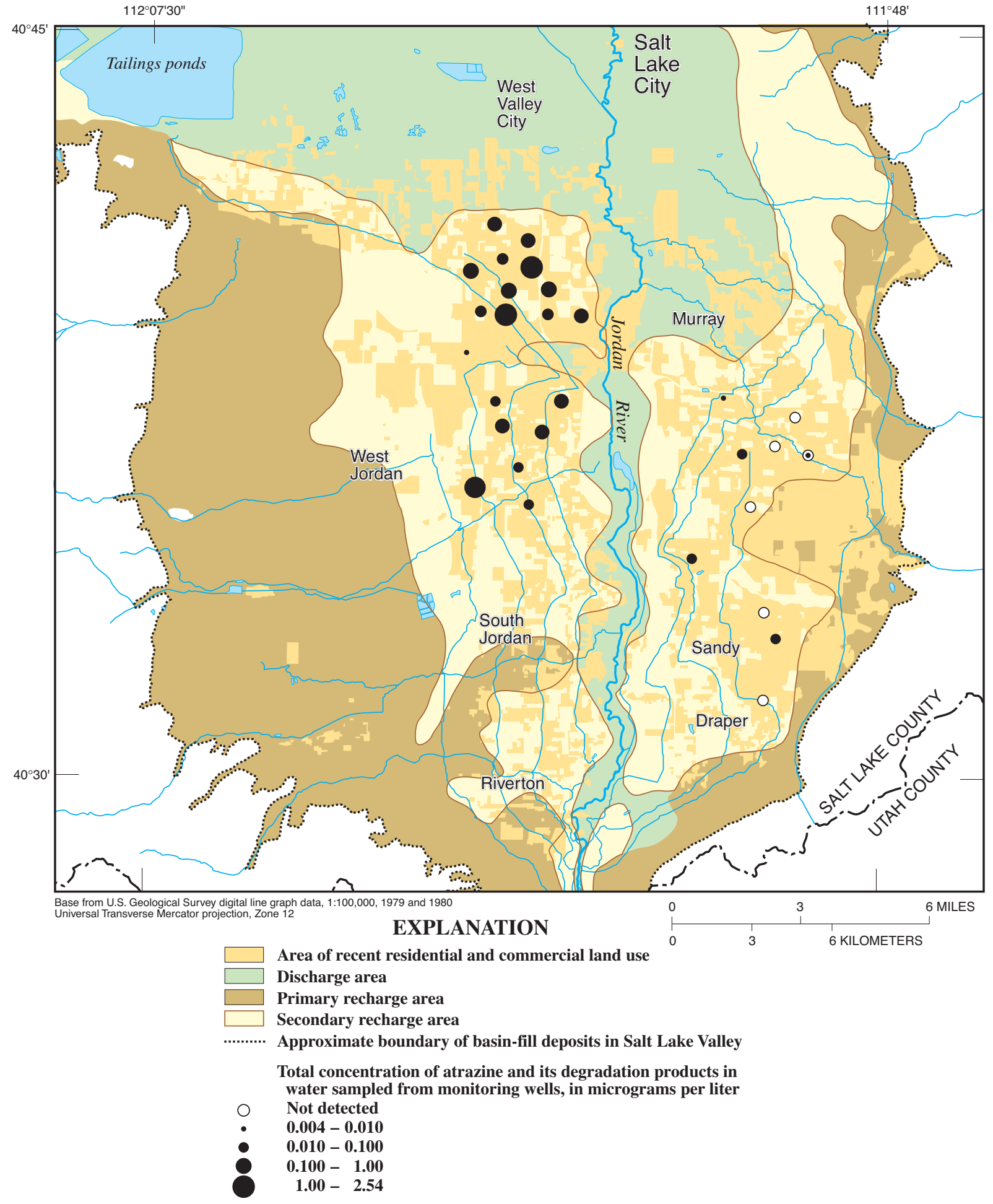

Figure 13. Total concentration of atrazine and its degradation products in water sampled from monitoring wells in areas of recent residential development, Salt Lake Valley, Utah. 


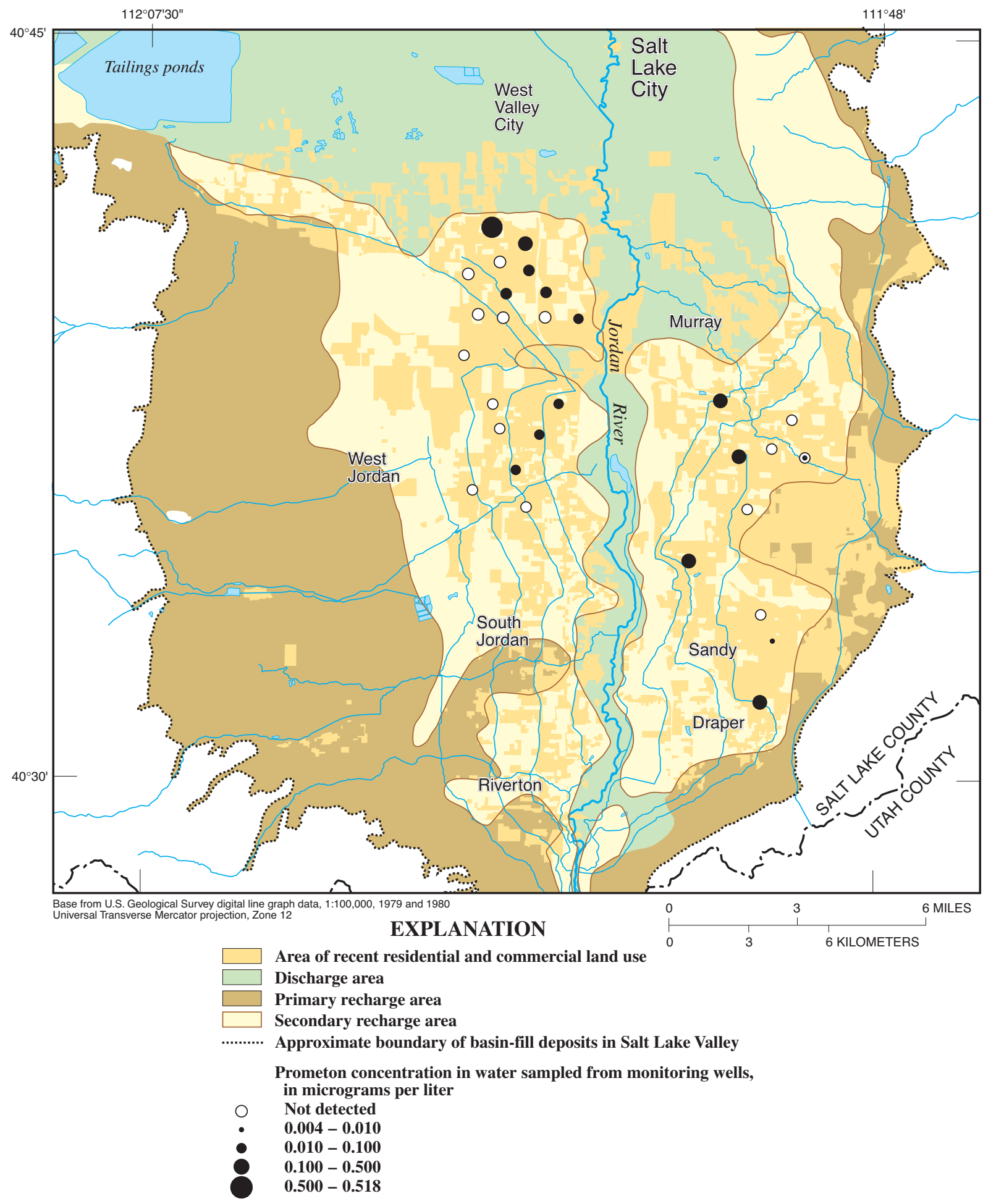

Figure 14. Prometon concentration in water sampled from monitoring wells in areas of recent residential development, Salt Lake Valley, Utah. 
lines. The U.S. Environmental Protection Agency (2002) has established MCLs in drinking water for more than 20 VOCs because of human health concerns.

Fifteen of the 86 VOCs analyzed for were detected in 1 or more water samples collected as part of this study (table 4). All of the VOCs analyzed for as part of this study are listed in table 12 (appendix). Detection of many VOCs is the result of improved analytical methods that allow measurement of lower concentrations (Conner and others, 1998). The most frequently detected VOCs were chloroform (90 percent), bromodichloromethane (56.7 percent), tetrachloroethylene (53.3 percent), and 1,1,1trichloroethane (50 percent) (fig. 15).
Chloroform and bromodichloromethane were detected in water from 27 and 17 wells, respectively (fig. 16). Generally, these compounds are byproducts of chlorinated ground and surface water that has reacted with organic material in the water and aquifer material, and are part of a group of VOCs known as trihalomethanes (THMs). These disinfection byproducts are regulated by the USEPA as total THMs with a cumulative MCL of $80 \mu \mathrm{g} / \mathrm{L}$ (U.S.

Environmental Protection Agency, 2002). The widespread occurrence of chloroform and bromodichloromethane in shallow ground water is likely a result of the recharge of chlorinated publicsupply water used to irrigate lawns and gardens in residential areas of Salt Lake Valley. Water disinfected

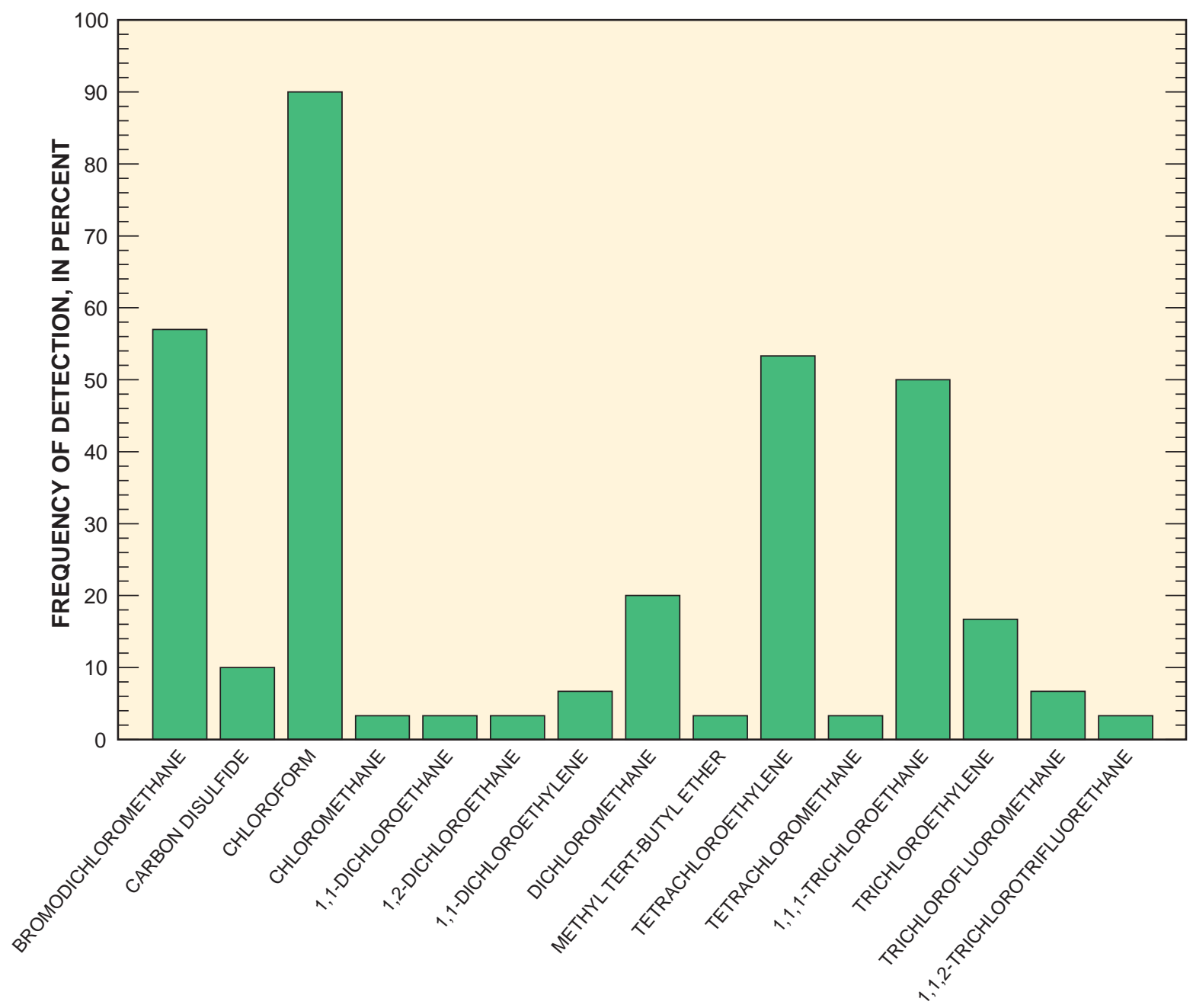

Figure 15. Detection frequency of volatile organic compounds in water sampled from monitoring wells in areas of recent residential development, Salt Lake Valley, Utah. 


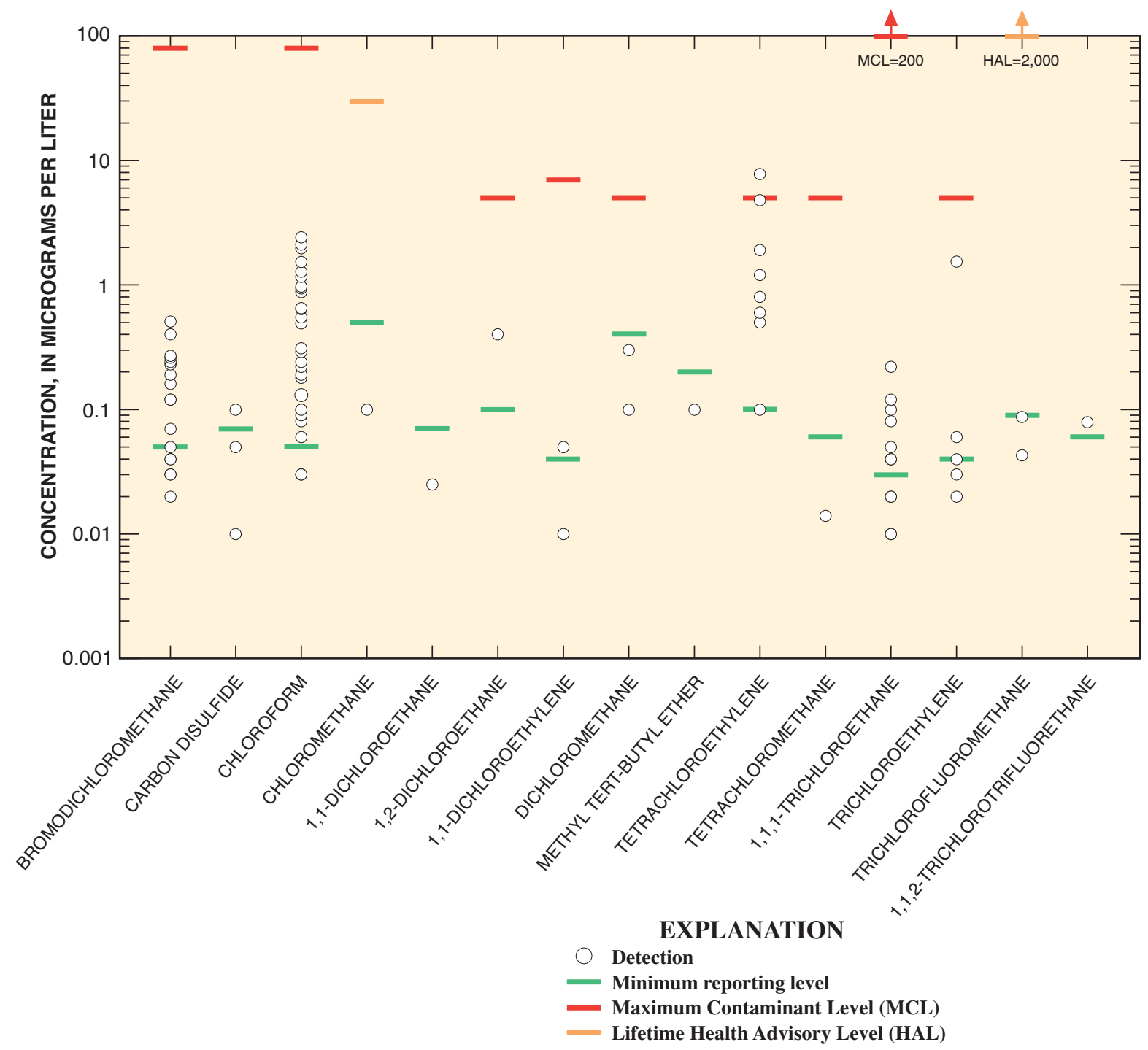

Figure 16. Concentration of selected volatile organic compounds in water sampled from monitoring wells in areas of recent residential development, Salt Lake Valley, Utah.

for public supply also can enter the ground-water system through leaking swimming pools, water lines, sewer lines, and septic systems.

Chloroform concentrations ranged from an estimated $0.03 \mu \mathrm{g} / \mathrm{L}$ to $2.41 \mu \mathrm{g} / \mathrm{L}$ (table 13 ), much less than the MCL for total THMs. Chloroform detected in monitoring wells is an indication that water treated for public supply is recharging the shallow ground-water system (fig. 17). The median chloroform concentration in water from the 30 monitoring wells was $0.28 \mu \mathrm{g} / \mathrm{L}$, $0.19 \mu \mathrm{g} / \mathrm{L}$ in water from 11 wells on the east side, and $0.55 \mu \mathrm{g} / \mathrm{L}$ in water from 19 wells on the west side of the valley.
Tetrachloroethylene (tetrachloroethene, perchloroethylene, PCE), primarily used as a dry cleaning agent and solvent, was detected in water from 16 wells (fig. 18). Although the median concentration for the 30 samples was less than the LRL of $0.1 \mu \mathrm{g} / \mathrm{L}$, water from 4 wells in the northwestern part of the valley had concentrations greater than $1 \mu \mathrm{g} / \mathrm{L}$ (wells 1 , 5, 8, and 9; table 13, appendix). The maximum PCE concentration detected in water from the monitoring wells in 1999 was $7.8 \mu \mathrm{g} / \mathrm{L}$ (well 5), which is greater than the MCL of $5 \mu \mathrm{g} / \mathrm{L}$ for drinking water (U.S. Environmental Protection Agency, 2002). 


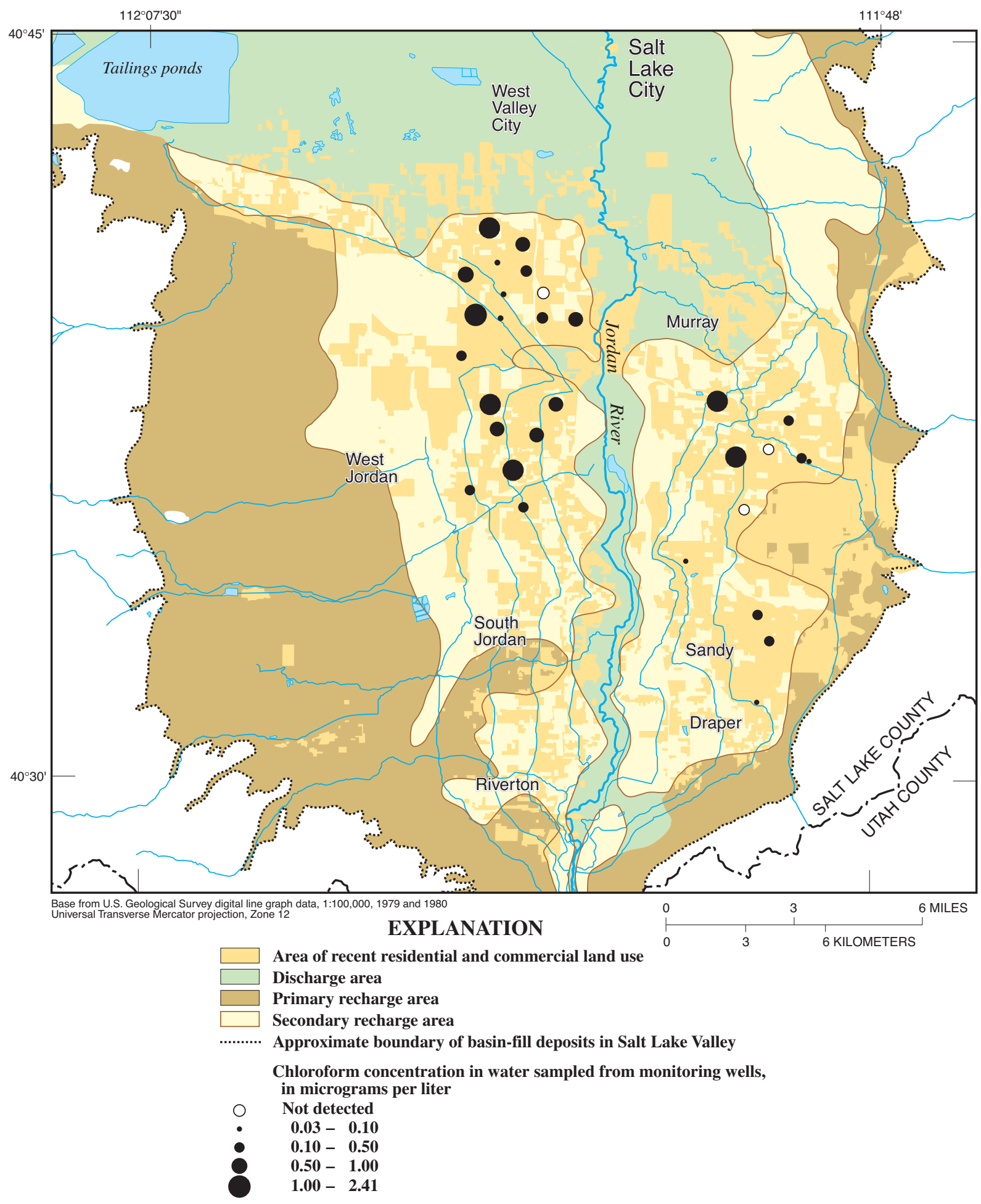

Figure 17. Chloroform concentration in water sampled from monitoring wells in areas of recent residential development, Salt Lake Valley, Utah. 


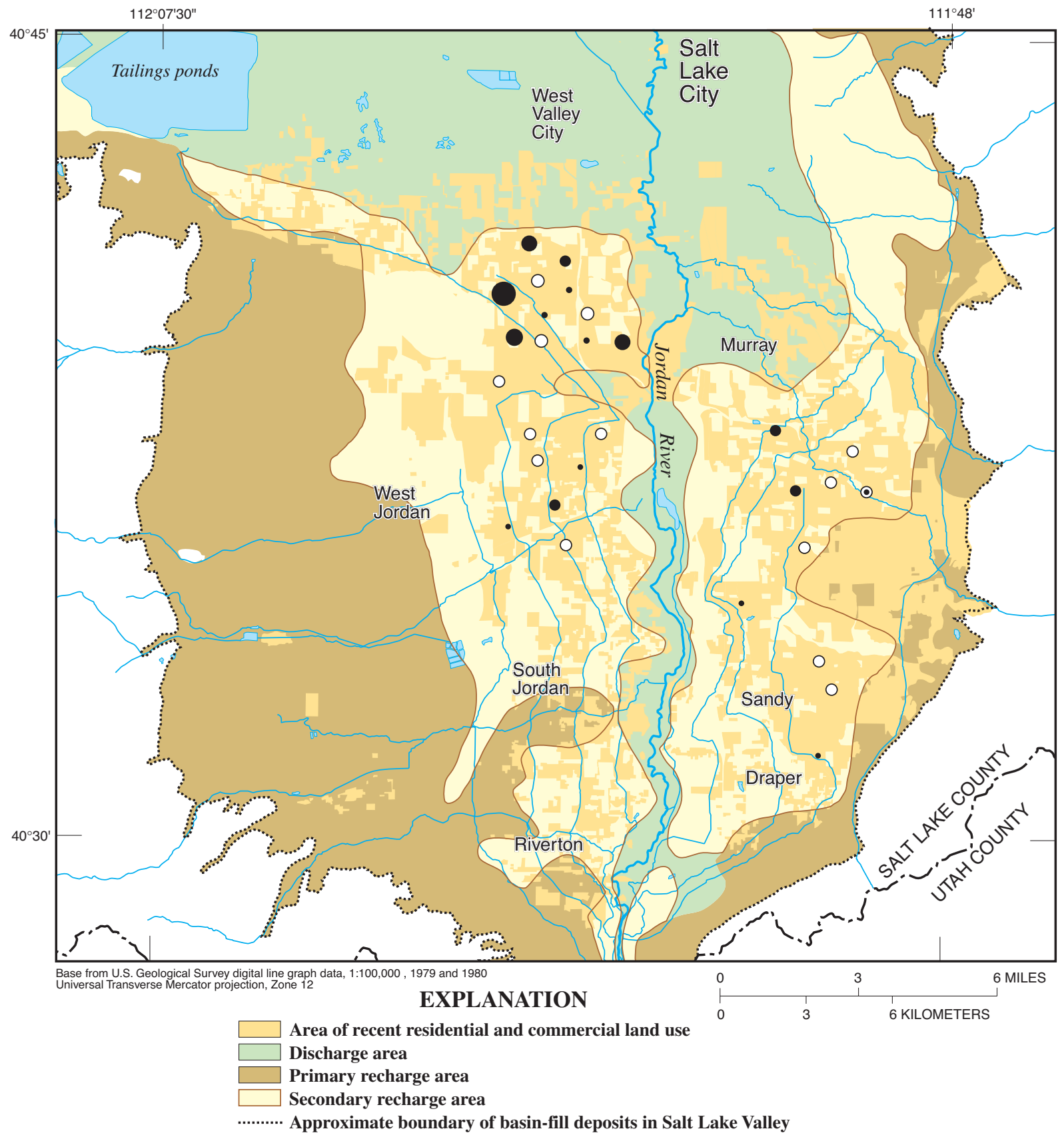

Tetrachloroethylene concentration in water sampled from monitoring wells, in micrograms per liter Not detected

Detected - 0.1

0.1 - 1.0

$1.0-5.0$

$5.0-7.8$

Figure 18. Tetrachloroethylene (PCE) concentration in water sampled from monitoring wells in areas of recent residential development, Salt Lake Valley, Utah. 
Resampling of well 27 on the east side of the valley showed an increase in PCE concentration from $0.8 \mu \mathrm{g} / \mathrm{L}$ in 1999 to $2.5 \mu \mathrm{g} / \mathrm{L}$ in 2000 , and to $10.0 \mu \mathrm{g} / \mathrm{L}$ in 2001. The increase in PCE concentration is an indication of ground water moving past the well from an upgradient source. Seasonal sampling of well 27 in 2000 showed a higher PCE concentration in June (6.0 $\mu \mathrm{g} / \mathrm{L})$ than in September $(2.5 \mu \mathrm{g} / \mathrm{L})$. Chloroform concentration also was higher in June $(4.52 \mu \mathrm{g} / \mathrm{L})$ as compared to September $(2.03 \mu \mathrm{g} / \mathrm{L})$. Water levels in well 27 fluctuated from $57.14 \mathrm{ft}$ below land surface in November 1999 to $60.33 \mathrm{ft}$ in June 2001 and are likely related to water applied to lawns and fields during the summer in the area that recharges the shallow aquifer. The water level in the well generally rises from JuneJuly until November and then falls from December until May-June. The higher PCE and chloroform concentrations in June may correspond with a reduction in recharge occurring in the winter and, therefore, less dilution of the contaminant plume.

Trichloroethylene (trichloroethene, TCE) is used mainly as a solvent, metal degreaser, and drying agent. Trichloroethylene was detected in water from five wells with concentrations ranging from an estimated 0.02 $\mu \mathrm{g} / \mathrm{L}$ (well 10) to $1.54 \mu \mathrm{g} / \mathrm{L}$ (well 2), less than the MCL of $5 \mu \mathrm{g} / \mathrm{L}$ (U.S. Environmental Protection Agency, 2002). An additional source of TCE can be the degradation of PCE under reducing conditions. Water from the five wells with TCE also contained PCE; reducing conditions were present in water from only three of these wells. Trichloroethylene concentration in water sampled from well 5 increased from an estimated $0.06 \mu \mathrm{g} / \mathrm{L}$ in 1999 to $0.08 \mu \mathrm{g} / \mathrm{L}$ in 2000 , and to 0.10 $\mu \mathrm{g} / \mathrm{L}$ in 2001 , and PCE concentration remained above 7 $\mu \mathrm{g} / \mathrm{L}$. The increase in TCE may indicate degradation of PCE or movement of water from a different contaminant plume to the well.

1,1,1-trichloroethane (methyl chloroform, TCA) was detected in water from 15 wells at concentrations ranging from an estimated $0.01 \mu \mathrm{g} / \mathrm{L}$ to $0.22 \mu \mathrm{g} / \mathrm{L}$ (table 13, appendix). It is generally used as a solvent and has an MCL of $200 \mu \mathrm{g} / \mathrm{L}$ (U.S. Environmental Protection Agency, 2002). 1,1,1-trichloroethane was detected in the atmosphere at concentrations greater than $0.05 \mu \mathrm{g} / \mathrm{L}$ in 84 percent of the air samples collected in an urban/residential area of New Jersey, but these concentrations correspond to concentrations in water of less than $0.002 \mu \mathrm{g} / \mathrm{L}$ (Baehr and others, 1999). Because of the widespread occurrence of TCA in shallow ground water in Salt Lake Valley at concentrations greater than assumed for atmospheric deposition, its presence in ground water is likely the result of activities at the land surface. TCA can degrade to dichloroethylene (DCE) under reducing conditions. Both compounds were detected in water from well 2 and, although a dissolved oxygen concentration indicative of reducing conditions was not measured, degradation of TCA may be occurring along the flow path.

The VOCs derived from gasoline were detected in five ground-water samples at concentrations lower than those estimated in the field-blank samples. Benzene; ethylbenzene; 1,2,4-trimethylbenzene; and $\mathrm{m}$ - and p-xylene were detected in water from wells 32 and 34 and may be from exhaust from the gasolinepowered generator used during sampling or from passing vehicles. These detections were not used in the VOC data analysis.

Methyl tert-butyl ether (MTBE) was detected at an estimated concentration of $0.1 \mu \mathrm{g} / \mathrm{L}$, near the LRL, in water from well 27 with no other gasoline-derived VOCs detected. This compound is used to oxygenate gasoline to improve combustion and reduce air-quality degradation. Because of the high solubility of MTBE in water, atmospheric washout in urban areas may be the source of low concentrations in ground water (Squillace and others, 1996). No MTBE was detected during resampling of water from well 27 in 2000 and 2001.

Urban stormwater runoff that flushes spills off of the land surface may be a source of certain VOCs in shallow ground water. Many of the same VOCs, such as PCE and TCE, were commonly detected in both stormwater and shallow ground water from urban areas across the United States (Lopes and Bender, 1998). Elevated concentrations of gasoline-related compounds (1,2,4-trimethylbenzene, xylene, and toluene) and TCE were measured during storm events in water sampled from Little Cottonwood Creek near the Jordan River (Gerner, 2003). Stormwater runoff that flows through or is retained in the primary or secondary recharge areas can recharge the shallow ground-water system along with any anthropogenic compounds that have been washed from the land surface. 


\section{SOURCES OF GROUND-WATER RECHARGE}

Environmental tracers were used to determine the sources of recharge to the shallow ground-water system in recently developed residential areas in the valley. The stable isotopes of water, deuterium, and oxygen-18 were used to differentiate between local precipitation and water that had been subjected to evaporation. Tritium, helium-3, and chlorofluorocarbons in the water were used to identify and approximately date ground water recharged within the past 50 years.

\section{Stable Isotopes}

The stable isotopes of water, deuterium (D or $\left.{ }^{2} \mathrm{H}\right)$ and oxygen-18 $\left({ }^{18} \mathrm{O}\right)$, can be used to determine recharge sources because they generally are conservative once they enter shallow ground-water systems. Small amounts of ${ }^{2} \mathrm{H}$ and ${ }^{18} \mathrm{O}$ are incorporated into the water molecule in average proportions of about 0.01 percent and 0.2 percent, respectively (Hem, 1989, p. 162). Oxygen and hydrogen isotope ratios, expressed as delta $(\delta){ }^{18} \mathrm{O}$ or $\delta^{2} \mathrm{H}$, are reported in parts per thousand (per mil) deviations from a reference standard called Vienna Standard Mean Ocean Water (VSMOW) (Coplen and others, 2000). Water with more negative per mil values has less ${ }^{18} \mathrm{O}$ and ${ }^{2} \mathrm{H}$ relative to ${ }^{16} \mathrm{O}$ and $\mathrm{H}$, respectively, and is lighter than water with less negative per mil values (heavier $\delta^{18} \mathrm{O}$ or $\delta^{2} \mathrm{H}$ values). The relation between $\delta^{18} \mathrm{O}$ and $\delta^{2} \mathrm{H}$ in precipitation is generally expressed by the equation $\delta^{2} \mathrm{H}=8 \delta^{18} \mathrm{O}+10$, known as the global meteoric water line (Craig, 1961). Ground water has an isotopic signature that is indicative of conditions at the time of recharge because ${ }^{18} \mathrm{O}$ and ${ }^{2} \mathrm{H}$ are generally conservative. Mixing with other recharge sources can alter this isotopic signature.

Values of $\delta^{18} \mathrm{O}$ or $\delta^{2} \mathrm{H}$ for water from most of the monitoring wells (table 5) plot off of the global meteoric water line because of evaporation (fig. 19). A line with a less steep slope can be drawn through water sampled from mountain-front streams, from the Jordan River at different sites and times of the year, and from canals that divert water from the Jordan River (fig. 19). Water from the mountain-front streams typically represents water that has not undergone evaporation, whereas water from canals diverted from the Jordan River has undergone evaporation. Precipitation occurring at lower altitudes, such as on the valley floor, likely plots higher on the global meteoric water line, with some offset as a result of evaporation, than does water from the mountain-front streams. Stable isotope ratios for water from the monitoring wells plot near a mixing line connecting the recharge sources of precipitation and evaporated diversion water. Ground water from the monitoring wells is a mixture of varying amounts of local precipitation and evaporated water, on the basis of stable isotope ratios.

Precipitation on the Wasatch Range and the Oquirrh Mountains is represented isotopically by samples from streams draining the mountains where they enter the valley. This water is isotopically light because the precipitation fell at higher altitudes and at colder temperatures than did precipitation at the valley floor. Stable isotope ratios for water from monitoring wells 26S, 26D, and 29 near Little Cottonwood Creek are similar to those for water from the creek at Crestwood Park (USGS streamflow-gaging station 10167800) (fig. 19). This similarity indicates that seepage from Little Cottonwood Creek is a source of recharge to the shallow ground-water system in the area.

Because of evaporation, canal water diverted from the Jordan River and used for irrigation is heavier in ${ }^{2} \mathrm{H}$ and ${ }^{18} \mathrm{O}$ relative to precipitation occurring locally or on the adjacent mountains. Evaporated water can recharge the shallow ground-water system through seepage and infiltration of unconsumed irrigation water. Water from wells 3, 7, and 11 on the west side of the valley is the heaviest in ${ }^{2} \mathrm{H}$ and ${ }^{18} \mathrm{O}$ of the 30 monitoring wells. Isotopic concentrations in local precipitation are probably represented by water from wells 8,14 , and 31 , which are upgradient from most of the canals on the west side of the valley. Water from the Utah and Salt Lake Canal in the southwestern part of the valley is much heavier isotopically because of evaporation. Water from wells 3, 7, and 11 plot about two-thirds of the way between the two potential sources of recharge-water represented by wells 8,14 , and 31 and water from the Utah and Salt Lake Canal (fig. 19). As a result, about two-thirds of the water from these wells is recharged from area canals if local precipitation and canal water are the primary sources of recharge. 
Table 5. Stable isotope ratio, tritium concentration, and apparent age for water sampled from 30 monitoring wells in areas of recent residential development, Salt Lake Valley, Utah

[Well identifier, see figure 3 for well location; per mil, parts per thousand; TU, tritium units; - , no data; Contaminated, concentration greater than what was possible for equilibrium with the atmosphere; Modern, within the possible range of modern air; >, greater than]

\begin{tabular}{|c|c|c|c|c|c|c|c|c|c|}
\hline \multirow[t]{2}{*}{$\begin{array}{c}\text { Well } \\
\text { identifier }\end{array}$} & \multirow[t]{2}{*}{$\begin{array}{l}\text { Well depth } \\
\text { (feet) }\end{array}$} & $\begin{array}{c}\text { Delta } \\
\text { oxygen-18 }\end{array}$ & $\begin{array}{c}\text { Delta } \\
\text { deuterium }\end{array}$ & Tritium & $\begin{array}{c}\text { Tritium } \\
\text { error }\end{array}$ & $\begin{array}{c}\text { Tritium/ } \\
\text { Helium-3 } \\
\text { apparent age }\end{array}$ & $\begin{array}{c}\text { 1CFC-11 } \\
\text { apparent age }\end{array}$ & $\begin{array}{c}{ }^{2} \mathrm{CFC}-12 \\
\text { apparent age }\end{array}$ & $\begin{array}{c}{ }^{3} \text { CFC-113 } \\
\text { apparent age }\end{array}$ \\
\hline & & \multicolumn{2}{|c|}{ (per mil) } & \multicolumn{2}{|c|}{ (TU) } & \multicolumn{4}{|c|}{ Years } \\
\hline 1 & 48.5 & -108.21 & -13.73 & 10.23 & 0.51 & - & Contaminated & Contaminated & Modern \\
\hline 2 & 38.5 & -102.38 & -13.02 & 12.28 & .61 & 13 & Contaminated & Contaminated & Contaminated \\
\hline 3 & 113.5 & -92.09 & -10.88 & 11.01 & .56 & 11 & Contaminated & Contaminated & Contaminated \\
\hline 4 & 38.5 & -114.70 & -14.90 & 1.67 & .08 & 38 & Contaminated & Contaminated & Modern \\
\hline 5 & 43.5 & -109.15 & -13.69 & 12.41 & .62 & 11 & Contaminated & Contaminated & 11 \\
\hline 6 & 38.5 & -96.46 & -11.58 & 11.83 & .59 & 3 & Contaminated & Contaminated & - \\
\hline 7 & 43.5 & -92.11 & -10.94 & 14.03 & .70 & - & Contaminated & Contaminated & 11 \\
\hline 8 & 67.5 & -112.36 & -14.38 & 14.77 & .74 & 4 & Contaminated & Contaminated & Contaminated \\
\hline 9 & 38.5 & -105.88 & -13.19 & 11.67 & .58 & 13 & Contaminated & Contaminated & 10 \\
\hline 10 & 83.5 & -97.32 & -11.78 & 16.60 & .85 & 8 & Contaminated & Contaminated & Contaminated \\
\hline 11 & 83.5 & -93.31 & -10.84 & 10.81 & .54 & - & Contaminated & Contaminated & Contaminated \\
\hline 14 & 48.5 & -111.92 & -14.61 & 8.00 & .40 & 6 & Contaminated & Contaminated & Contaminated \\
\hline 17 & 38.5 & -98.31 & -12.01 & 11.34 & .57 & 12 & 21 & Contaminated & 23 \\
\hline 18 & 106 & -112.04 & -14.99 & 10.50 & .50 & 4 & Contaminated & Contaminated & Contaminated \\
\hline 20 & 92.5 & -104.24 & -13.26 & 19.70 & .99 & - & Contaminated & Contaminated & 12 \\
\hline 22 & 36 & -113.66 & -14.89 & 19.67 & .98 & 24 & Contaminated & Contaminated & 10 \\
\hline 24 & 123.5 & -98.03 & -11.93 & 20.30 & 1.01 & 8 & Contaminated & Contaminated & 10 \\
\hline 25 & 68.5 & -98.00 & -11.86 & 18.92 & .95 & 8 & Contaminated & Contaminated & Contaminated \\
\hline $26 \mathrm{D}$ & 77.5 & -118.96 & -16.30 & 12.42 & .62 & - & Contaminated & Contaminated & Modern \\
\hline $26 \mathrm{~S}$ & 31 & -115.92 & -15.98 & 13.25 & .66 & 0 & Modern & Modern & 10 \\
\hline 27 & 73.5 & -110.24 & -14.42 & 10.43 & .52 & 3 & Contaminated & Contaminated & Contaminated \\
\hline 29 & 34 & -118.98 & -16.42 & 54.76 & 2.74 & 32 & 48 & 26 & $>44$ \\
\hline 30 & 68.5 & -100.23 & -12.61 & 11.56 & .58 & 1 & Contaminated & Contaminated & Contaminated \\
\hline 31 & 153.5 & -112.42 & -14.25 & 17.79 & .89 & 1 & Contaminated & Contaminated & 8 \\
\hline 32 & 88.5 & -111.23 & -14.76 & 8.89 & .44 & 6 & Contaminated & Contaminated & 12 \\
\hline 33 & 96 & -102.12 & -12.71 & 19.30 & .96 & 15 & Contaminated & Contaminated & Contaminated \\
\hline 34 & 77.5 & -105.30 & -13.80 & 2.84 & .42 & - & Contaminated & Contaminated & Modern \\
\hline 37 & 73 & -112.19 & -14.77 & 23.96 & 1.20 & 38 & Contaminated & Contaminated & 14 \\
\hline 39 & 106 & -114.59 & -15.02 & 9.39 & .47 & 0 & Contaminated & Contaminated & Modern \\
\hline 41 & 23 & - & - & 13.19 & .66 & 0 & Contaminated & Contaminated & 9 \\
\hline
\end{tabular}

Because the monitoring wells are located in residential areas, a potential source of recharge to the shallow ground-water system is water used for public supply. Public-supply water in Salt Lake Valley is primarily from mountain-front streams and from the principal aquifer and is used to irrigate lawns and gardens. Stable isotope ratios for ground water from the principal aquifer on the east side of Salt Lake Valley are similar to those for water from the mountainfront streams, which indicates that precipitation originating at higher altitudes is a main source of recharge (Thiros, 1995). Water supplied to the public may undergo some evaporation during lawn and garden irrigation and other household uses before it infiltrates into the ground. Wells 22, 32, 37, and 39 on the east side of the valley are upgradient from canals diverted from the Jordan River, but contain a component of evaporated water on the basis of stable isotope ratios (fig. 19). Chloroform was detected in water from these 


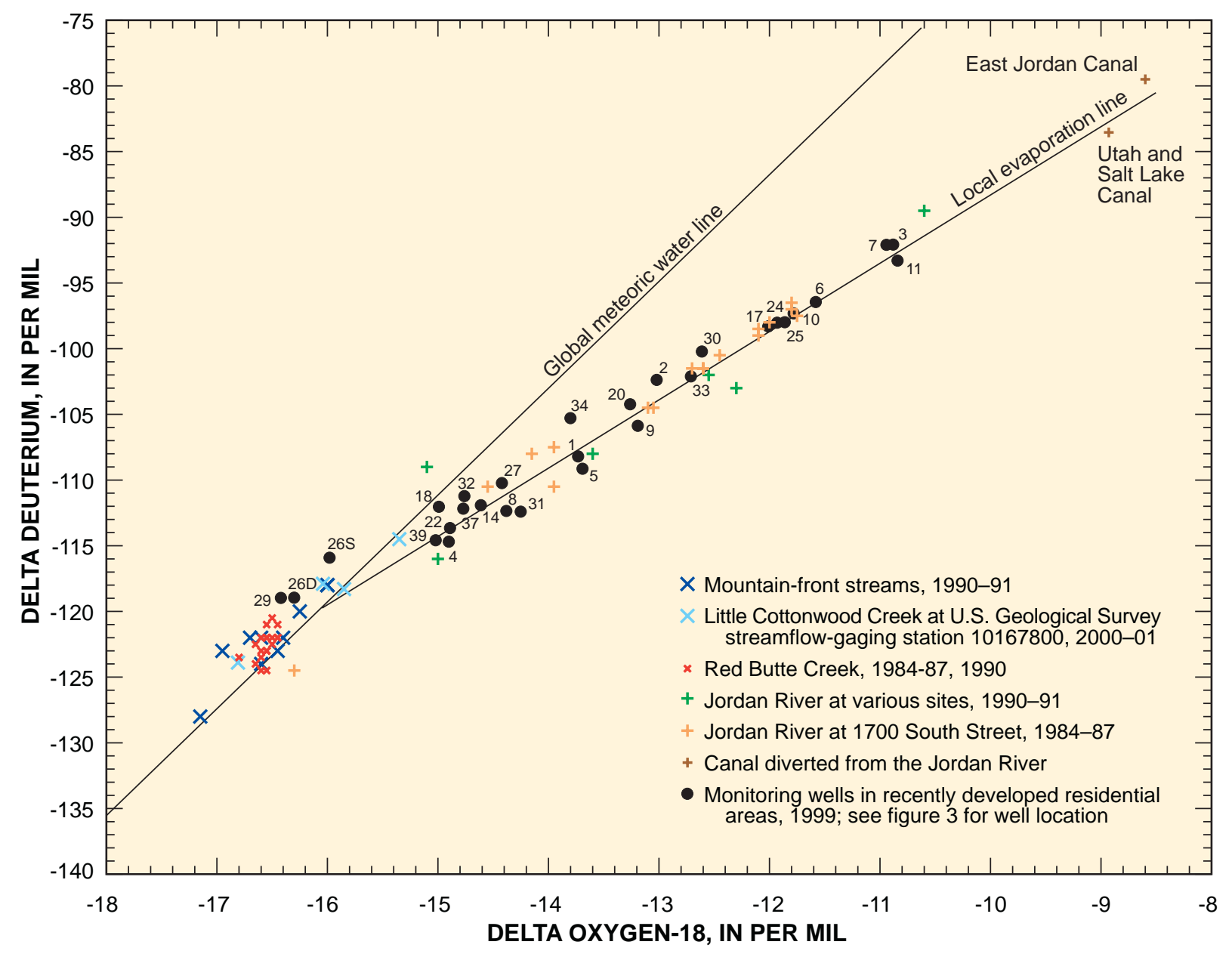

Figure 19. Relation between delta deuterium and delta oxygen-18 for shallow ground-water and surface-water samples from Salt Lake Valley, Utah.

wells; thus, the water is likely a mixture of infiltration from local precipitation and seepage of public-supply water used for irrigation.

Seasonal measurements of $\delta^{18} \mathrm{O}$ and $\delta^{2} \mathrm{H}$ were taken from water in monitoring wells $26 \mathrm{~S}, 26 \mathrm{D}, 27$, and 32. Seasonal samples also were collected from a 38.5 -ft-deep monitoring well about $1,270 \mathrm{ft}$ downgradient from well 32 in a sprinkler-irrigated field of grass, and from Little Cottonwood Creek at Crestwood Park (USGS streamflow-gaging station 10167800) (fig. 20). These wells are on the east side of the valley near the mouth of Little Cottonwood Canyon where the unconsolidated basin fill is made up primarily of permeable deltaic deposits from the mountain front. Wells $26 \mathrm{~S}$ and 26D are next to Little
Cottonwood Creek, and water from well 26S shows the greatest variation in stable isotope ratios with time, generally following changes in streamflow in the creek. Peak snowmelt runoff in the creek occurs in June with lighter $\delta^{18} \mathrm{O}$ and $\delta^{2} \mathrm{H}$ values that represent higheraltitude precipitation. Some of this water recharges the shallow ground-water system monitored by well $26 \mathrm{~S}$, which is indicated by lighter isotopic ratios measured in ground water sampled in May as compared to other times of the year. Water temperature and water level in wells $26 \mathrm{~S}$ and 26D fluctuate in a similar fashion.

Delta deuterium and $\delta^{18} \mathrm{O}$ values in water from Little Cottonwood Creek at Crestwood Park measured in March, April, and August are heavier than those measured in June and may represent the effects of 
evaporation of stream water, local sources of recharge, and (or) shallow ground-water discharge. Water from four public-supply wells completed in the principal aquifer in the area has a range in $\delta^{18} \mathrm{O}$ and $\delta^{2} \mathrm{H}$ values similar to that of water from Little Cottonwood Creek (fig. 20).

Delta deuterium and $\delta^{18} \mathrm{O}$ values for water from well 32 did not vary as much with time as did water from well 26S because the well is farther away from seasonal recharge sources and has a greater depth to the water table. Recharge of sprinkler-irrigation water to the shallow system was observed isotopically in the 38.5-ft deep monitoring well near well 32. The water level measured in the well during 2000-2001 fluctuated from a high of $23.30 \mathrm{ft}$ below land surface in October (after the irrigation season) to a low of $26.33 \mathrm{ft}$ in April (before the irrigation season). Stable isotope ratios were heaviest in the summer when water was applied to the area upgradient from the monitoring well and became lighter in the winter and spring when no irrigation occurred (fig. 20). Water from well 27 showed a similar seasonal variation.

\section{Tritium and Tritium/Helium-3}

Water from the 30 monitoring wells was analyzed for tritium to determine apparent age (table 5). Tritium is a radioactive isotope of hydrogen $\left({ }^{3} \mathrm{H}\right)$ with a half-life of 12.43 years. Large quantities of tritium were added to the atmosphere from above ground thermonuclear testing beginning about 1952 and provide a marker for precipitation from the testing period. Concentrations in precipitation prior to atmospheric thermonuclear testing have been estimated to be 3 to 6 TU (Kaufmann and Libby, 1954). Tritium concentration in water recharged to the basin-fill deposits prior to 1952, assuming no mixing with other

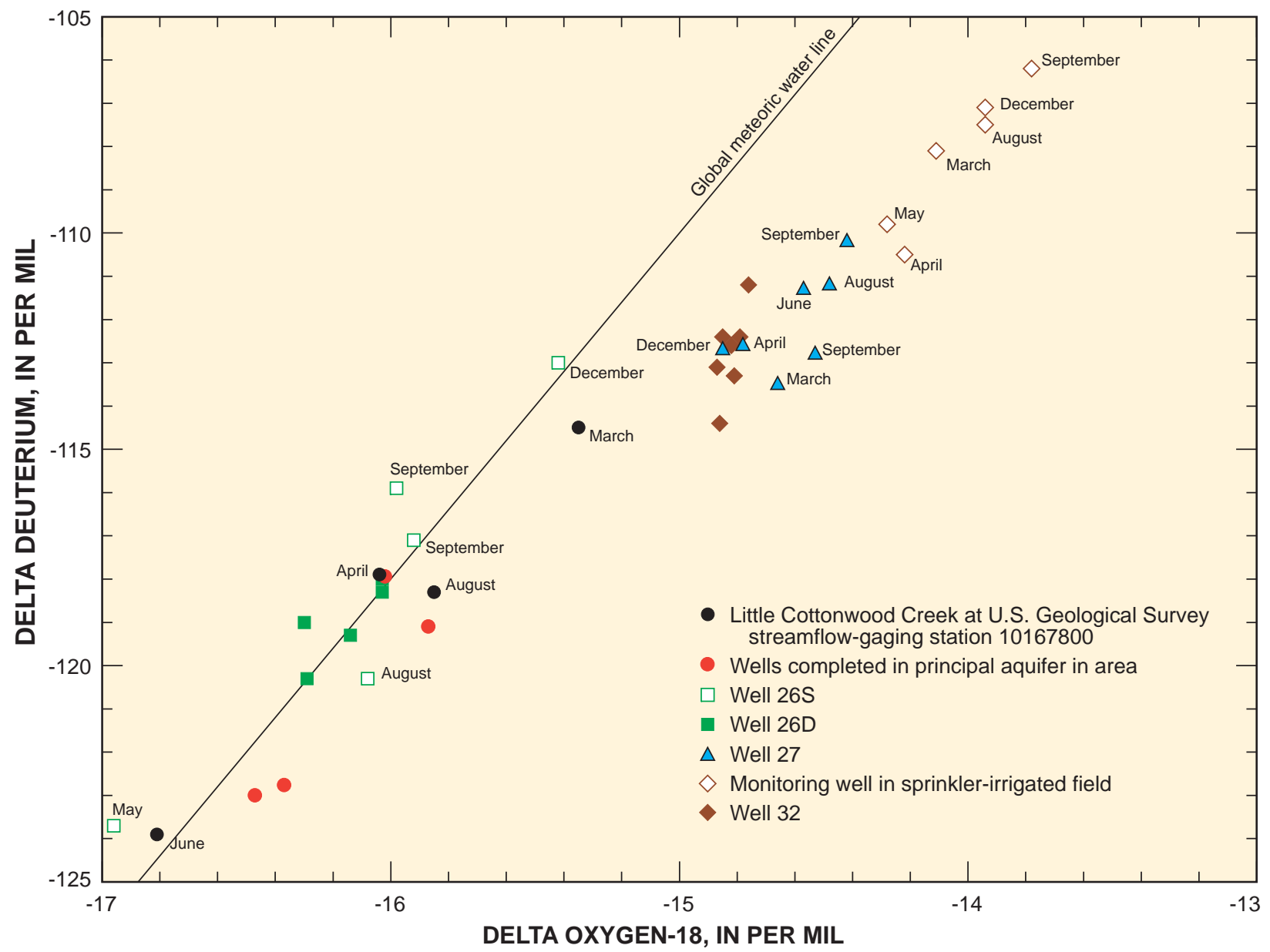

Figure 20. Relation between delta deuterium and delta oxygen-18 for water samples from selected wells and from Little Cottonwood Creek, Salt Lake Valley, Utah. 
sources, would have decayed to less than 1 TU by 1999 and resulted in about a 50-year timescale. The amount of tritium in precipitation collected in Vienna, Austria, in 1999 varied from 8.0 TU in December to $17.3 \mathrm{TU}$ in June (International Atomic Energy Agency, 2001) and is gradually decreasing toward pre-1952 levels. Concentrations greater than that of present day indicate that the water or a component of the water has been recharged since 1952.

Tritium decays to the noble gas helium-3 $\left({ }^{3} \mathrm{He}\right)$, the stable isotope of helium. The ratio of ${ }^{3} \mathrm{H}$ to ${ }^{3} \mathrm{He}$ derived from ${ }^{3} \mathrm{H}$ decay in a water sample can be used to determine the time from when water containing ${ }^{3} \mathrm{H}$ became isolated from the atmosphere (ground-water age). The ${ }^{3} \mathrm{H} /{ }^{3} \mathrm{He}$ dating method requires quantification of ${ }^{3} \mathrm{He}$ from ${ }^{3} \mathrm{H}$ by accounting for ${ }^{3} \mathrm{He}$ from other sources (Solomon and Cook, 2000). The ${ }^{3} \mathrm{H} /{ }^{3} \mathrm{He}$ clock does not start until water is below the water table and completely isolated from the gas phase because tritiogenic ${ }^{3} \mathrm{He}$ generated in the unsaturated zone is effectively lost to the atmosphere and is not measured in the water sample, resulting in younger ages determined by the method. Uncertainty in age because of analytical uncertainty is approximately \pm 0.5 year. Larger uncertainties in age can result because of the variable tritium input with time, mixing caused by dispersion, and losses to the gas phase at the water table. Because of the variable nature of the ${ }^{3} \mathrm{H}$ input and dispersive mixing, ${ }^{3} \mathrm{H} /{ }^{3} \mathrm{He}$ dating is less certain for waters older than the mid-1960s bomb pulse.

Tritium concentrations greater than $1 \mathrm{TU}$ in water from all of the monitoring wells (table 5) confirm a component of recharge to the shallow ground-water system after atmospheric thermonuclear testing began in 1952. Water from most of the wells had a tritium concentration of from 10 to $20 \mathrm{TU}$, a range that most likely is made up of water recharged from the present to about 15 years ago and within the timeframe of residential development in the area of the wells. The apparent age from ${ }^{3} \mathrm{H} /{ }^{3} \mathrm{He}$ data for water from 24 monitoring wells ranged from 1 year or less to 38 years old, relative to 1999 (table 5). Water from 20 of the wells became isolated from the atmosphere 0 to 15 years before 1999 on the basis of ${ }^{3} \mathrm{H} /{ }^{3} \mathrm{He}$ dating.

Wells $26 \mathrm{~S}$ and 41 are the shallowest wells in the study (31 and $23 \mathrm{ft}$, respectively) and contain water 1 year or less old. Water temperature, water level, and stable isotope ratio changes confirm recent recharge to well 26S from Little Cottonwood Creek. Rapid recharge to the ground-water system is possible in other areas where recharge sources and permeable aquifer material occur, such as along creeks and canals in the primary and secondary recharge areas. Some of the deepest monitoring wells also contained water that recharged the water table within the last 2 years. Depth to water in wells 30,31 , and 39 is about 58,143 , and 94 $\mathrm{ft}$ below land surface, respectively. The time spent in the unsaturated zone is not included in the ${ }^{3} \mathrm{H} /{ }^{3} \mathrm{He}$ age determination and may be considerable depending on the amount of recharge, the permeability, and the thickness of unsaturated deposits overlying the water table.

Tritium concentrations in water from the monitoring wells determined from ${ }^{3} \mathrm{H} /{ }^{3} \mathrm{He}$ ages and corrected for radioactive decay over time generally are similar to those measured in or extrapolated for precipitation (fig. 21). The correlation between tritium in recently recharged ground water and precipitation indicates that most or all of the water in the shallow system is from the land surface with little or no mixing with older water.

The lowest tritium concentration (1.67 TU) was measured in water from well 4 (table 5) and represents a component of water recharged before the tritium peak in 1963 caused by atmospheric testing. The ${ }^{3} \mathrm{H} /{ }^{3} \mathrm{He}$ apparent age determined for this water is about 1962 . The tritium concentration in 1962 , based on a concentration of $1.67 \mathrm{TU}$ in water from well 4 in 1999 and a half-life of 12.43 years, is about 13 TU (fig. 21). Tritium concentration measured in precipitation in Salt Lake City is available for 1963-84 and has been extrapolated from 1961 to 2000 on the basis of correlation with data from Vienna, Austria (Robert Michel, U.S. Geological Survey, written commun., 2002) (fig. 21). Extrapolated monthly tritium concentrations in 1961-62 precipitation ranged from about 35 to 1,600 TU, much higher than $13 \mathrm{TU}$ determined from the ${ }^{3} \mathrm{H} /{ }^{3} \mathrm{He}$ apparent age. These values would have decayed to about 4 to $200 \mathrm{TU}$ in 1999 rather than the $1.67 \mathrm{TU}$ measured in water from well 4 . Because higher tritium concentrations were not measured in water from well 4 , older water with no tritium probably is mixing with younger, tritiated water, resulting in a younger apparent age.

The highest tritium concentration (54.76 TU) was measured in water from well 29 and represents a large component of water recharged in the 1960s when the peak in tritium concentrations in the atmosphere occurred. This water, on the basis of the ${ }^{3} \mathrm{H} /{ }^{3} \mathrm{He}$ method, was isolated from the atmosphere and 


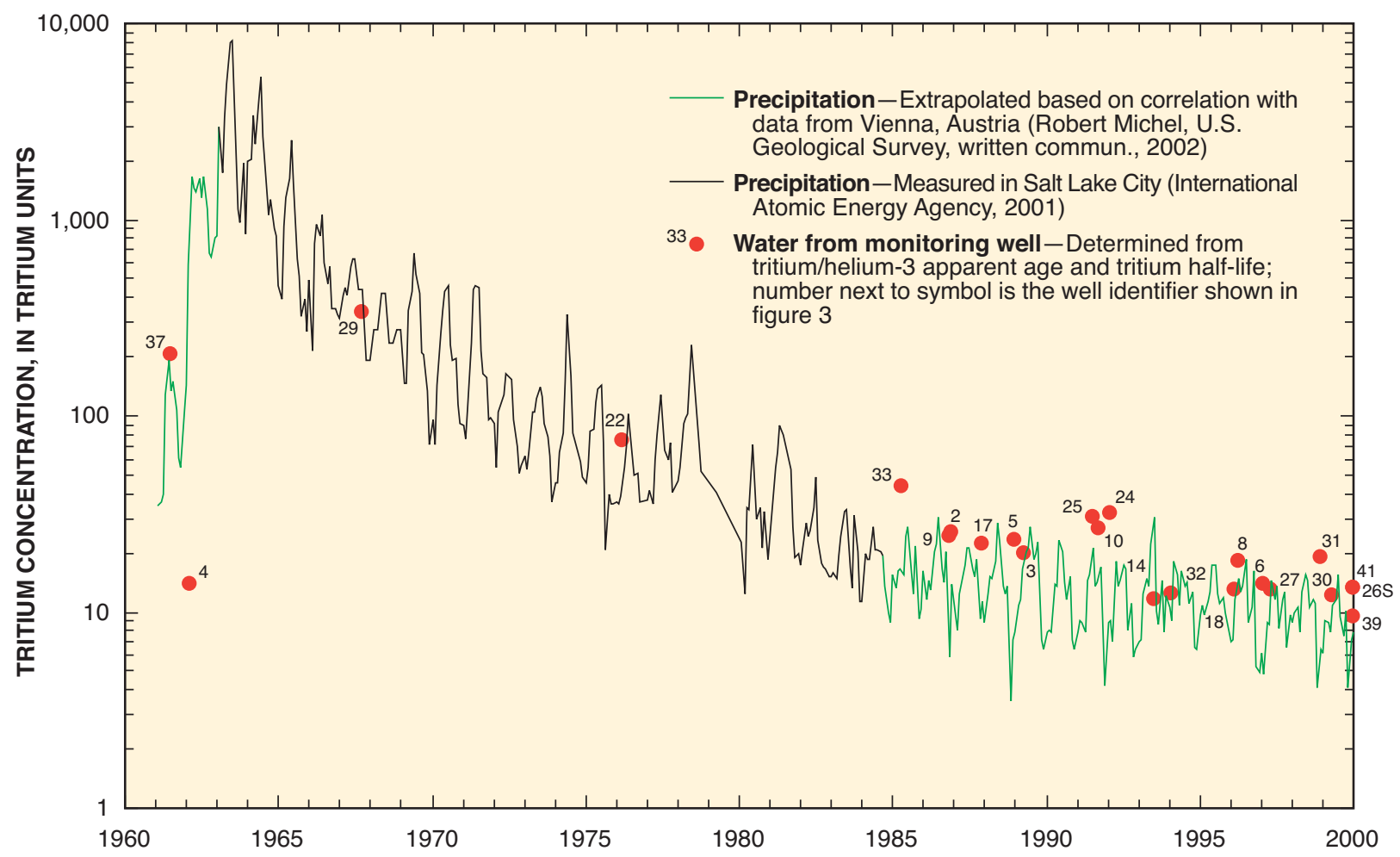

Figure 21. Tritium concentration in precipitation and in water sampled from monitoring wells in areas of recent residential development, Salt Lake Valley, Utah.

recharged the shallow ground-water system in 1967. Tritium measured in Salt Lake City precipitation in 1967 would have decayed to about the concentration measured in 1999 on the basis of a half-life of 12.43 years. Many of the samples from the monitoring wells on the west side of the valley plot slightly above the line representing tritium concentration in precipitation (fig. 21). This may be the result of mixing with water recharged during the preceding 20 to 30 years that has been impeded by clay layers.

\section{Chlorofluorocarbons}

Chlorofluorocarbons (CFCs) are synthetic organic compounds that were developed in the early 1930s as coolants in air conditioning and refrigeration (Plummer and Friedman, 1999). Other uses included blowing agents in foams, insulation, and packing materials, propellants in aerosol cans, and as solvents in the electronics industry. Chlorofluorocarbons are used as environmental tracers and dating tools for water that has been in contact with the atmosphere since the 1940s. Ground-water samples from the monitoring wells were analyzed for CFC-11 (trichlorofluoromethane or $\mathrm{CFCl}_{3}$ ), $\mathrm{CFC}-12$ (dichlorodifluoromethane or $\mathrm{CF}_{2} \mathrm{Cl}_{2}$ ), and $\mathrm{CFC}-113$ (trichlorotrifluoroethane or $\mathrm{C}_{2} \mathrm{~F}_{3} \mathrm{Cl}_{3}$ ) (table 5). Ground-water age is estimated by relating the measured concentration of the environmental tracer in water to the historical atmospheric concentration and to a calculated concentration expected in water in equilibrium with air.

Apparent ground-water ages determined in this study from CFC concentrations generally are similar to ages determined by using the ${ }^{3} \mathrm{H} /{ }^{3} \mathrm{He}$ method (table 5). Water sampled from well 29 had CFC-11 and CFC-113 concentrations that corresponded to a time of recharge before 1955. The water from this well is anoxic, which can degrade these compounds and result in apparent older CFC ages. CFC-12 does not decay under sulfatereducing conditions and provided an age date of 1973 that is closer to the ${ }^{3} \mathrm{H} /{ }^{3} \mathrm{He}$ date of 1967 for this water sample. Most of the water samples had CFC concentrations that were greater than what was possible for equilibrium with the atmosphere. Ground water from these wells was contaminated with CFCs from 
anthropogenically affected sources with concentrations in excess of that of atmospheric sources. CFC-11 was detected in water sampled from two monitoring wells, and CFC-113 was detected in water from one well in the parts per billion range as part of the VOC analysis. Although a recharge date cannot be determined from these contaminated samples, the presence of CFCs indicates that the water has been in contact with human activities at the land surface.

\section{EFFECTS OF SHALLOW GROUND-WATER QUALITY ON DEEPER GROUND-WATER QUALITY}

Water from the deeper aquifer underlying the shallow ground-water system is used for public supply in Salt Lake Valley. The potential exists for movement of anthropogenic compounds from shallow ground water to the deeper aquifer in recently developed residential areas where a downward hydraulic gradient exists between the aquifers. The monitoring wells installed for this study were located in areas assumed to have a downward hydraulic gradient from the shallow to the deeper aquifer on the basis of information from well-drillers' logs (Anderson and others, 1994). Contamination of the principal aquifer from activities at land surface has been documented in the valley (Waddell and others, 1987).

Water used for public supply from the principal aquifer in Salt Lake Valley was sampled as part of the NAWQA program. Many of the sampled wells in the primary and secondary recharge areas had a component of water that was recharged during the last 50 years (contained detectable tritium) and had detectable concentrations of chloroform. Even in some areas with an upward gradient between the deeper and shallow aquifers, anthropogenic compounds were detected, indicating a connection with land surface. Changes in water-level gradients caused by pumping may result in water movement from the shallow to the deeper aquifer.

Water levels in monitoring wells on the east side of the valley ranged from about 5 to $94 \mathrm{ft}$ below land surface. Shallow ground water is perched about $300 \mathrm{ft}$ above the deeper aquifer by confining layers in the area of wells 29, 32, and 34. The shallow and deeper ground-water systems in this area are separated by sequences of fine-grained deposits that perch the shallow ground water and confine the deeper aquifer. Different sources of recharge also contribute to the large downward gradient between the two systems: subsurface inflow from the Wasatch Range to the deeper aquifer, and local precipitation and unconsumed irrigation water to the shallow system. Anthropogenic compounds were not detected in water sampled from monitoring well 32 or a nearby public-supply well completed in the deeper confined aquifer. The deeper confined aquifer in this part of the valley is probably more isolated from activities occurring at the land surface because of confining layers and different recharge sources.

Water levels in monitoring wells in the northwestern part of the valley ranged from about 12 to $80 \mathrm{ft}$ below land surface. No large hydraulic gradient exists between the shallow and deeper aquifers in this area despite the presence of confining layers. Anthropogenic compounds are more prevalent in the shallow ground water. Pumping from the deeper aquifer may cause water to move downward from the shallow aquifer in some areas. Fewer wells pump water from the deeper aquifer in the secondary recharge area on the west side of Salt Lake Valley than on the east side generally because of poorer yield and chemical quality.

Anthropogenic compounds were detected in water from both monitoring well 8 and a nearby publicsupply well completed in the deeper confined aquifer on the west side of the valley. Atrazine concentrations were about an order of magnitude higher in water from the deeper well $(0.195 \mu \mathrm{g} / \mathrm{L})$ than in water from the shallower monitoring well $(0.023 \mu \mathrm{g} / \mathrm{L})$. Water from the deeper well and well 8 had chloroform concentrations of $0.66 \mu \mathrm{g} / \mathrm{L}$ and $1.16 \mu \mathrm{g} / \mathrm{L}$, respectively, and PCE concentrations of $1.0 \mu \mathrm{g} / \mathrm{L}$ and $1.9 \mu \mathrm{g} / \mathrm{L}$, respectively. The water levels in both wells were similar under static conditions (about $60 \mathrm{ft}$ below land surface) but dropped almost $100 \mathrm{ft}$ in the deeper well when pumping. A thick layer of clay noted on the drillers' log of the deeper well (124-182 ft below land surface) occurs between the water table and the top of the screened interval. The specific-conductance value of water was about $1,000 \mu \mathrm{S} / \mathrm{cm}$ in the shallow well under both static and pumping conditions and in water from the deeper well while pumping. The specificconductance value of water in the deeper well at about $90 \mathrm{ft}$ below land surface under static conditions was $350 \mu \mathrm{S} / \mathrm{cm}$ and is probably representative of the water in the aquifer at the screened interval $(172-253 \mathrm{ft}$ below 
land surface). The occurrence of VOCs in water pumped from the deeper well may be caused by shallow water that has moved downward despite the presence of the intervening clay layer. The higher concentration of atrazine in the deeper well may result from water recharged at land surface where the herbicide was used in the primary recharge area.

The water level in monitoring well 31 in the southwestern part of the valley is about $140 \mathrm{ft}$ below land surface, similar to that of domestic wells in the area. The anthropogenic compounds chloroform, PCE, TCA, atrazine, and simazine were present in water from this well despite the relatively deep water table. The boundary between the shallow and deeper aquifers in this area is not clearly defined because of thin and (or) discontinuous confining layers. Water from local precipitation and seepage from unconsumed irrigation and canals, primary sources of recharge to the shallow aquifer, also may be major sources of recharge to the deeper aquifer in the area. Where this is the case, activities occurring at land surface have the potential to affect the water quality of the deeper confined aquifer in the southwestern part of the valley. Contamination of the principal aquifer from mine-waste water that was impounded at land surface occurred downgradient from the Bingham Canyon mining area (Waddell and others, 1987, p. 19), but upgradient from major confining layers.

\section{RELATION BETWEEN GROUND-WATER QUALITY AND LAND USE}

The relation between the concentration of selected constituents and compounds in ground-water samples collected from the monitoring wells and the type of land use within 1,640 ft of each well was examined by using statistical correlation. The Spearman rank correlation test was used to measure the strength of association between two variables (Helsel and Hirsch, 1992, p. 209-218). The correlation coefficient (rho) varies from 1 to -1 and describes the strength of the correlation. Values closer to 1 indicate a positive correlation, values closer to -1 indicate an inverse correlation, and values closer to 0 indicate no correlation. The p-value (probability of no correlation) was used to evaluate the significance of the correlation; p-values less than 0.10 are considered statistically significant.
No correlation was determined between the percentage of residential land use surrounding the monitoring wells and the concentration of dissolved solids, arsenic, atrazine and its degradation products, prometon, chloroform, or nitrate in water sampled from the wells. The total percentage of land classified as commercial, vacant, and roads weakly correlated with the concentration of atrazine and its degradation products in water sampled from the wells $(p=0.06$, rho $=0.35$ ). Atrazine applied to these land-use types may be a source of atrazine detected in the shallow ground water. Not enough agricultural land was delineated within $1,640 \mathrm{ft}$ of the monitoring wells to determine if it is correlated to atrazine concentration in ground water. The source of atrazine and its degradation products also may be from areas more than $1,640 \mathrm{ft}$ upgradient from the wells. In addition, chloroform concentration in the water samples did not correlate to percentages of these land-use types.

Dissolved-solids concentration strongly correlated with ${ }^{2} \mathrm{H}(\mathrm{p}=0.0001$, rho $=0.76)$, confirming that isotopically heavier irrigation water contains more dissolved solids than does isotopically lighter water recharged from mountain-front streams or local precipitation. Chloroform concentration did not correlate with dissolved-solids or nitrate concentration in water from the monitoring wells, probably because of mixing of recharge sources and different sources of nitrate. The relation between chloroform and the herbicides atrazine and prometon, although not statistically significant, varied differently. The three highest chloroform concentrations corresponded to three of the four highest prometon concentrations, likely because of the use of these compounds in residential areas. Relatively low concentrations of chloroform corresponded to the four highest concentrations of atrazine and its degradation products, probably because of atrazine use on agricultural or nonirrigated industrial and vacant land.

\section{SUMMARY}

Residential and commercial development of about $80 \mathrm{mi}^{2}$ that primarily replaced undeveloped and agricultural areas occurred in Salt Lake Valley, Utah, from 1963 to 1994. This study evaluated the occurrence and distribution of natural and anthropogenic constituents in shallow ground water underlying 
recently developed (post 1963) residential and commercial areas. Monitoring wells from 23 to $153 \mathrm{ft}$ deep were installed at 30 sites. Ground-water quality for the monitoring wells was evaluated by using analyses of field parameters, major ions, trace elements, radon, nutrients, dissolved organic carbon, pesticides, and volatile organic compounds.

Dissolved-solids concentration ranged from 134 to $2,910 \mathrm{mg} / \mathrm{L}$ in water from the 30 monitoring wells. Dissolved arsenic concentration in water from 12 wells exceeded the drinking water maximum contaminant level of $10 \mu \mathrm{g} / \mathrm{L}$. Water from monitoring wells in the northwestern part of the valley generally had higher arsenic concentrations than did water from other areas. Nitrate concentration in water sampled from 26 of the 30 monitoring wells ( 86.7 percent) was higher than a background level of $2 \mathrm{mg} / \mathrm{L}$, indicating a possible human influence. Nitrate concentrations ranged from less than 0.05 to $13.3 \mathrm{mg} / \mathrm{L}$.

Fifteen of the 104 pesticides and pesticide degradation products analyzed for were detected in 1 or more water samples from the monitoring wells. No pesticides were detected at concentrations that exceeded U.S. Environmental Protection Agency drinking-water standards or guidelines. for 2002 Total concentration of pesticides and pesticide degradation products in water ranged from an estimated $0.002 \mu \mathrm{g} / \mathrm{L}$ (diazinon) to $2.56 \mu \mathrm{g} / \mathrm{L}$ (a mixture of atrazine, atrazine degradation products, and simazine). The high detection frequency of atrazine, a restricted-use pesticide, in residential areas on the west side of Salt Lake Valley may be the result of application in agricultural or industrial areas that have been converted to residential uses or application in areas upgradient from the residential areas that was then transported by ground water.

Fifteen of the 86 volatile organic compounds analyzed for were detected in 1 or more water samples from the monitoring wells. The most frequently detected volatile organic compounds were chloroform (90 percent), bromodichloromethane (56.7 percent), tetrachloroethylene (53.3 percent), and 1,1,1trichloroethane (50 percent). The widespread occurrence of chloroform and bromodichloromethane in shallow ground water is likely a result of chlorinated public-supply water used to irrigate lawns and gardens in residential areas of Salt Lake Valley.

Tetrachloroethylene (PCE), primarily used as a dry cleaning agent and solvent, was detected in water from 16 wells. Resampling of water from a well on the east side of the valley showed an increase in PCE concentration from $0.8 \mu \mathrm{g} / \mathrm{L}$ in 1999 , to $2.5 \mu \mathrm{g} / \mathrm{L}$ in 2000 , and to $10.0 \mu \mathrm{g} / \mathrm{L}$ in 2001 . This upward trend is an indication of ground water containing PCE moving past the well from an upgradient source.

Stable isotopes indicate that ground water from the monitoring wells is a mixture of varying amounts of local precipitation and evaporated water. Because of evaporation, canal water diverted from the Jordan River and used for irrigation is isotopically heavier relative to precipitation occurring locally or on the adjacent mountains. Several wells on the east side of the valley are upgradient from canals that divert water from the Jordan River but contain a component of evaporated water. Chloroform was detected in water from these wells; thus, the water is likely a mixture of infiltration from local precipitation and seepage of water used for public supply. Recharge of sprinkler-irrigation water to the shallow ground-water system was observed isotopically in a 38.5-ft-deep monitoring well. Stable isotope ratios were heaviest in the summer when water was applied to the area upgradient from the monitoring well and became lighter in the winter and spring when no irrigation occurred.

Water from most of the wells had a tritium concentration of from 10 to 20 tritium units, a range that indicates ground water recharged from the present to about 15 years ago and within the timeframe of residential development in the area of the wells. The match between tritium in shallow ground water and precipitation indicates that most or all of the water in the shallow system is recent recharge from the land surface with little or no mixing with older ground water. Water from most of the monitoring wells was contaminated with chlorofluorocarbons, which also indicates that the water has been in contact with human activities at the land surface.

Subsurface inflow from the Wasatch Range is the main source of recharge to the deeper aquifer on the east side of the valley, and local precipitation and irrigation water are the main sources of recharge to the shallow system. As a result, the deeper aquifer in this part of the valley is more isolated than the shallow ground water from activities occurring at the land surface. No large hydraulic gradient exists between the shallow and deeper aquifers in the northwestern part of the valley and anthropogenic compounds are more prevalent in the shallow ground water. Pumping from the deeper confined aquifer, however, may cause water and anthropogenic compounds to move downward 
from the shallow aquifer. The anthropogenic compounds chloroform, tetrachloroethylene, 1,1,1trichloroethane, atrazine, and simazine were present in water from a monitoring well in the southwestern part of the valley despite the relatively deep water table. Water from local precipitation and seepage from irrigation and canals, primary sources of recharge to the shallow aquifer, also may be major sources of recharge to the deeper aquifer in this area because of thin or discontinuous confining layers. Where this is the case, activities occurring at land surface have the potential to affect the water quality of the deeper aquifer.

No correlation was determined between the percentage of residential land use surrounding the monitoring wells and the concentration of dissolved solids, arsenic, atrazine and its degradation products, prometon, chloroform, or nitrate in water sampled from the wells. Chloroform concentration did not correlate with dissolved-solids or nitrate concentration in water from the monitoring wells; this may be a result of mixing of different sources of recharge and nitrate. Relatively low concentrations of chloroform corresponded to the four highest concentrations of atrazine and its degradation products; this may be a result of atrazine use on agricultural or nonirrigated industrial and vacant land.

\section{REFERENCES CITED}

American Society for Testing and Materials, 1996, Annual book of ASTM standards, section 11, Water and environmental technology: American Society for Testing and Materials, v. 11.02, D5072-92, p. 674-676.

Anderson, P.B., Susong, D.D., Wold, S.R., Heilweil, V.M., and Baskin, R.L., 1994, Hydrogeology of recharge areas and water quality of the principal aquifers along the Wasatch Front and adjacent areas, Utah: U.S. Geological Survey Water-Resources Investigations Report 93-4221, 74 p.

Baehr, A.L., Stackelberg, P.E., and Baker, R.J., 1999, Evaluation of the atmosphere as a source of volatile organic compounds in shallow groundwater: Water Resources Research, v. 35, no. 1, p. 127-136.

Barbash, J.E., Thelin, G.P., Kolpin, D.W., and Gilliom, R.J., 1999, Distribution of major herbicides in ground water of the United States: U.S. Geological Survey WaterResources Investigations Report 98-4245, p. 8.
Bayer, R., Schlosser, P., Bönisch, G., Rupp, H., Zaucker, F., and Zimmek, G., 1989, Performance and blank components of a mass spectrometric system for routine measurement of helium isotopes and tritium by the ${ }^{3} \mathrm{He}$ ingrowth method, in Sitzungsberichte der Heidelberger Akademie der Wissenschaften, Mathematisch-naturwissenschaftliche Klasse: Heidelberg, Springer Verlag, v. 5, p. 241-279.

Brenton, R.W., and Arnett, T.L., 1993, Methods of analysis by the U.S. Geological Survey National Water-Quality Laboratory-Determination of dissolved organic carbon by UV_-promoted persulfate oxidation and infrared spectrometry: U.S. Geological Survey OpenFile Report 92-480, 12 p.

Busenberg, E., and Plummer, L.N., 1992, Use of chlorofluorocarbons $\left(\mathrm{CCl}_{3} \mathrm{~F}\right.$ and $\left.\mathrm{CCl}_{2} \mathrm{~F}_{2}\right)$ as hydrologic tracers and age-dating tools: Example-The alluvium and terrace system of central Oklahoma: Water Resources Research, v. 28, p. 2257-2284.

Capel, P.D., Spexet, A.H., and Larson, S.J., 1999, Occurrence and behavior of the herbicide Prometon in the hydrologic system: Environmental Science \& Technology, v. 33, no. 5, p. 674-880.

Childress, C.J., Foreman, W.T., Connor, B.F., and Maloney, T.J., 1999, New reporting procedures based on longterm method detection levels and some considerations for interpretations of water-quality data provided by the U.S. Geological Survey National Water-Quality Laboratory: U.S. Geological Survey Open-File Report 99193, 19 p.

Ciba-Geigy Corporation, 1994, Pramitol 25E, Product ID 51325: Ciba-Geigy Corp, Greensboro, N.C.

Conner, B.F., Rose, D.L., Noriega, M.C., Murtagh, L.K., and Abney, S.R., 1998, Methods of analysis by the U.S. Geological Survey National Water-Quality Laboratory-Determination of 86 volatile organic compounds in water by gas chromatography/mass spectrometry, including detections less than reporting limits: U.S. Geological Survey Open-File Report 97-829, 78 p.

Coplen, T.B., Wildman, J.D., and Chen, J., 1991, Improvements in the gaseous hydrogen-water equilibration technique for hydrogen isotope ratio analysis: Analytical Chemistry, v. 63, no. 9, p. 910-912.

Coplen, T.B., Herczeg, A.L., and Barnes, C., 2000, Isotope engineering-Using stable isotopes of the water molecule to solve practical problems, in Environmental Tracers in Subsurface Hydrology, Peter G. Cook and Andrew L. Herczeg, eds., Boston, Kluwer Academic Publishers, p. 79-110.

Craig, H., 1961, Isotopic variations in meteoric waters: Science, v. 133, p. 1702-1703.

Crecelius, E.A., 1975, The geochemical cycle of arsenic in Lake Washington and its relation to other elements: Limnology and Oceanography, v. 20, no. 3, p. 441-451. 
Epstein, S., and Mayeda, T., 1953, Variation of O-18 content of water from natural sources: Geochemica et Cosmochimica Acta, v. 4, p. 213-224.

Faires, L.M., 1993, Methods of analysis by the U.S. Geological Survey National Water-Quality Laboratory-Determination of metals in water by inductively coupled plasma-mass spectrometry: U.S. Geological Survey Open-File Report 92-634, 28 p.

Fishman, M.J., ed., 1993, Methods of analysis by the U.S. Geological Survey National Water-Quality Laboratory-Determination of inorganic and organic constituents in water and fluvial sediments: U.S. Geological Survey Open-File Report 93-125, 217 p.

Fishman, M.J., and Friedman, L.C., 1989, Methods for determination of inorganic substances in water and fluvial sediments: U.S. Geological Survey Techniques of Water-Resources Investigations, book 5, chap. A1, 545 p.

Furlong, E.T., Anderson, B.D., Werner, S.L., Soliven, P.P., Coffey, L.J., and Burkhardt, M.R., 2001, Methods of analysis by the U.S. Geological Survey National WaterQuality Laboratory-Determination of pesticides in water by graphitized carbon-based solid-phase extraction and high-performance liquid chromatography/mass spectrometry: U.S. Geological Survey Water-Resources Investigations Report 01-4134, 73 p.

Gerner, S.J., 2003, Hydrology and water quality of an urban stream reach in the Great Basin-Little Cottonwood Creek near Salt Lake City, Utah, water years 19992000: U.S. Geological Survey Water-Resources Investigations Report 02-4276, 48 p.

Halberg, G.R., and Keeney, D.R., 1993, Nitrate, in Alley, W.M., ed., Regional ground-water quality: New York, Van Nostrand Reinhold, p. 316.

Helsel, D.R., and Hirsch, R.M., 1992, Statistical methods in water resources: New York, Elsevier Science Publishers, $522 \mathrm{p}$.

Hely, A.G., Mower, R.W., and Harr, C.A., 1971, Water resources of Salt Lake County, Utah: Utah Department of Natural Resources Technical Publication No. 21, 244 p.

Hem, J.D., 1989, Study and interpretation of the chemical characteristics of natural water, third edition: U.S. Geological Survey Water-Supply Paper 2254, 263 p.

International Atomic Energy Agency, 2001, Isotope Hydrology Information System: the ISOHIS Database, accessed June 11, 2002, at URL http://isohis.iaea.org

Kada, J., Heit, M., and Miller, K.M., 1994, Chronology of anthropogenic trace element input to four Utah lakes reconstructed using sediment cores: Water, Air and Soil Pollution, Netherlands, Kluwer Academic Publishers, no. 75, p. 353-369.

Kaufmann, S., and Libby, W.F., 1954, The natural distribution of tritium: Physics Review, v. 93, p. 1337-1344.
Koterba, M.T., 1998, Ground-water data-collection protocols and procedures for the National Water-Quality Assessment Program: Collection, documentation, and compilation of required site, well, subsurface, and landscape data for wells: U.S. Geological Survey WaterResources Investigations Report 98-4107, 125 p.

Koterba, M.T., Wilde, F.D., and Lapham, W.W., 1995, Ground-water data-collection protocols and procedures for the National Water-Quality Assessment Program: Collection and documentation of water-quality samples and related data: U.S. Geological Survey Open-File Report 95-399, 113 p.

Lapham, W.W., Wilde, F.D., and Koterba, M.T., 1995, Ground-water data-collection protocols and procedures for the National Water-Quality Assessment Program: selection, installation, and documentation of wells, and collection of related data: U.S. Geological Survey Open-File Report 95-398, 69 p.

Lopes, T.J., and Bender, D.A., 1998, Nonpoint sources of volatile organic compounds in urban areas-Relative importance of land surfaces and air: Environmental Pollution, no. 101, p. 221-230.

Patton, C.J., and Truitt, E.P., 1992, Methods of analysis by the U.S. Geological Survey National Water-Quality Laboratory-Determination of total phosphorus by a Kjeldahl digestion method and an automated colorimetric finish that includes dialysis: U.S. Geological Survey Open-File Report 92-146, 39 p.

Plummer, L.N., and Friedman, L.C., 1999, Tracing and dating young ground water: U.S. Geological Survey Fact Sheet FS-134-99.

Scott, J.C., 1990, Computerized stratified random site-selection approaches for design of ground-water-quality network: U.S. Geological Survey Water-Resources Investigations Report 90-4101, 109 p.

Solomon, D.K., and Cook, P.G., 2000, ${ }^{3} \mathrm{H}$ and ${ }^{3} \mathrm{He}$, in Environmental Tracers in Subsurface Hydrology, Peter G. Cook and Andrew L. Herczeg, eds., Boston, Kluwer Academic Publishers, p. 397-424.

Squillace, P.J., Pankow, J.F., Korte, N.E., and Zogorski, J.S., 1996, Environmental behavior and fate of methyl tertbutyl ether (MTBE): U.S. Geological Survey Fact Sheet FS-203-96.

Squillace, P.J., and Price, C.V., 1996, Urban land-use study plan for the National Water-Quality Assessment Program: U.S. Geological Survey Open-File Report 96217, $19 \mathrm{p}$.

Thiros, S.A., 1995, Chemical composition of ground water, hydrologic properties of basin-fill material, and groundwater movement in Salt Lake County, Utah: Utah Department of Natural Resources Technical Publication No. 110-A, 59 p.

2003, Hydrogeology of shallow basin-fill deposits in areas of Salt Lake Valley, Salt Lake County, Utah: U.S. 
Geological Survey Water-Resources Investigations Report 03-4029, 23 p.

Timme, P.J., 1995, National Water-Quality Laboratory 1995 services catalog: U.S. Geological Survey Open-File Report 95-352, p. 92.

U.S. Census Bureau, 2002, Quick facts for Salt Lake County, Utah, accessed December 12, 2002, at URL http://quickfacts.census.gov/qfd/states/49/49035.html

U.S. Environmental Protection Agency, 1999, Fact Sheet: Proposed radon in drinking water rule, U.S. Environmental Protection Agency Publication EPA 815-F-99006, accessed April 29, 2002, at URL http://www.epa.gov/safewater/radon/fact.html 2002, 2002 edition of the drinking water standards and health advisories: Office of Water, EPA 822-R-02038, accessed October 5, 2002, at URL http://www.epa.gov/waterscience/ drinking/standards/dwstandards.pdf.

U.S. Geological Survey, 1999, The quality of our Nation's waters - Nutrients and pesticides: U.S. Geological Survey Circular 1225, $82 \mathrm{p}$.

Utah Department of Natural Resources, Division of Water Resources, 1995, Land use/water related use, accessed May 10, 2002, at URL http://agric.utah.gov/sgid/statewide/index.html

1999, A water-related land use summary report of the State of Utah, accessed May 10, 2002, at URL http://www.water.utah.gov/planning/landuse/wrlui.pdf
Waddell, K.M., Seiler, R.L., Santini, M., and Solomon, D.K., 1987, Chemical quality of ground water in Salt Lake Valley, Utah, 1969-85: Utah Department of Natural Resources Technical Publication No. 89, 55 p.

Wasatch Front Regional Council, 2000, Population projections for Utah's cities and unincorporated areas, 20002030: Utah's Associations of Government and Governor's Office of Planning and Budget Demographic and Economic Analysis, accessed May 10, 2002, at URL http://governor.state.ut.us/dea/demographics/2000FinalPublish.pdf

Welch, A.H., and Lico, M.S., 1998, Factors controlling As and $U$ in shallow ground water, southern Carson Desert, Nevada: Applied Geochemistry, v. 13, no. 4, p. 521539.

Welch, A.H., Westjohn, D.B., Helsel, D.R., and Wanty, R.B., 2000, Arsenic in ground water of the United States, occurrence and geochemistry: Ground Water, v. 38, no. 4, p. 589-604.

Zaugg, S.D., Sandstrom, M.W., Smith, S.G., and Fehlberg, K.M., 1995, Methods of analysis by the U.S. Geological Survey National Water-Quality Laboratory-Determination of pesticides in water by $\mathrm{C}-18$ solid-phase extraction and capillary-column gas chromatography/mass spectrometry with selected-ion monitoring: U.S. Geological Survey Open-File Report 95-181, 49 p. 


\section{APPENDIX}

Table 6. Field parameters for water sampled from monitoring wells in Salt Lake Valley, Utah, 1999

[Well identifier corresponds to site shown in figure 3; well identification number is the site number used in the U.S. Geological Survey National Water Information System; $\mu \mathrm{S} / \mathrm{cm}$, microsiemens per centimeter at 25 degrees Celsius; $\mathrm{mg} / \mathrm{L}$, milligrams per liter; NTU, nephelometric turbidity units; $\mu \mathrm{g} / \mathrm{L}$, micrograms per liter; <, less than; - , no data]

\begin{tabular}{|c|c|c|c|c|c|c|c|c|c|c|c|c|}
\hline $\begin{array}{l}\text { Well } \\
\text { identifier }\end{array}$ & $\begin{array}{c}\text { Well identification } \\
\text { number }\end{array}$ & $\begin{array}{l}\text { Sample } \\
\text { date }\end{array}$ & $\begin{array}{c}\text { Depth of } \\
\text { well } \\
\text { (feet) }\end{array}$ & $\begin{array}{c}\text { Water } \\
\text { level } \\
\text { below } \\
\text { land } \\
\text { surface } \\
\text { (feet) }\end{array}$ & $\begin{array}{c}\text { Tempera- } \\
\text { ture } \\
\text { (degrees } \\
\text { Celsius) }\end{array}$ & $\begin{array}{c}\text { Specific } \\
\text { conduc- } \\
\text { tance } \\
(\mu \mathrm{S} / \mathrm{cm})\end{array}$ & $\begin{array}{c}\text { pH } \\
\text { (standard } \\
\text { units) }\end{array}$ & $\begin{array}{c}\text { Alka- } \\
\text { linity, } \\
\text { dissolved } \\
\text { (mg/L as } \\
\mathrm{CaCO}_{3} \text { ) }\end{array}$ & $\begin{array}{c}\text { Oxygen, } \\
\text { dissolved } \\
\text { (mg/L) }\end{array}$ & $\begin{array}{l}\text { Turbidity } \\
\text { (NTU) }\end{array}$ & $\begin{array}{c}\text { Chlorine } \\
\text { ( } \mu \mathrm{g} / \mathrm{L})\end{array}$ & $\begin{array}{c}\text { Sulfide } \\
\text { ( } \mu \mathrm{g} / \mathrm{L})\end{array}$ \\
\hline 1 & 404104111582101 & $09 / 22 / 1999$ & 48.5 & 30.91 & 15.5 & 1,340 & 7.3 & 375 & 4.9 & 0.6 & $<30$ & 40 \\
\hline 2 & 404044111572701 & 09/20/1999 & 38.5 & 18.66 & 16.0 & 2,740 & 6.9 & 433 & 4.4 & .2 & 40 & 10 \\
\hline 3 & 404022111580801 & $10 / 19 / 1999$ & 114 & 74.67 & 19.0 & 1,520 & 7.3 & 294 & 6.3 & .2 & $<30$ & 10 \\
\hline 4 & 404012111572101 & 09/20/1999 & 38.5 & 13.35 & 17.0 & 2,030 & 7.5 & 250 & 2.5 & .6 & $<30$ & $<10$ \\
\hline 5 & 404007111585801 & 09/27/1999 & 43.5 & 24.80 & 16.0 & 1,370 & 7.4 & 256 & 6.6 & .1 & $<30$ & $<10$ \\
\hline 6 & 403945111565401 & $10 / 07 / 1999$ & 38.5 & 20.73 & 16.5 & 2,850 & 6.9 & 659 & - & 1.6 & $<30$ & $<10$ \\
\hline 7 & 403943111575701 & 09/28/1999 & 43.5 & 21.38 & 16.5 & 1,790 & 7.3 & 313 & 5.8 & .2 & $<30$ & 240 \\
\hline 8 & 403918111584201 & 10/18/1999 & 67.5 & 62.47 & 16.5 & 760 & 7.5 & 191 & 7.0 & 4.0 & $<30$ & $<10$ \\
\hline 9 & 403914111560101 & 09/28/1999 & 38.5 & 7.96 & 15.0 & 2,190 & 7.2 & 374 & 1.8 & .7 & $<30$ & $<10$ \\
\hline 10 & 403915111565501 & 10/13/1999 & 83.5 & 72.48 & 18.5 & 3,000 & 7.3 & 274 & 5.2 & .1 & $<30$ & $<10$ \\
\hline 11 & 403914111580201 & $10 / 06 / 1999$ & 83.5 & 67.12 & 18.0 & 2,150 & 7.1 & 369 & 4.7 & .2 & $<30$ & 10 \\
\hline 14 & 403828111590401 & 09/30/1999 & 48.5 & 23.31 & 16.5 & 1,440 & 7.5 & 324 & 3.3 & 4.4 & $<30$ & 10 \\
\hline 17 & 403730111563201 & 09/23/1999 & 38.5 & 14.29 & 15.5 & 3,440 & 7.1 & 462 & .7 & .2 & $<30$ & 10 \\
\hline 18 & 403736111521401 & 09/13/1999 & 106 & 77.55 & 16.0 & 1,030 & 7.2 & 327 & 6.7 & 2.4 & 50 & $<10$ \\
\hline 20 & 403729111581701 & $10 / 05 / 1999$ & 92.5 & 80.99 & 16.5 & 3,700 & 7.3 & 404 & 6.7 & .1 & $<30$ & 10 \\
\hline 22 & 403713111501901 & 09/29/1999 & 36 & 20.29 & 14.0 & 650 & 7.5 & 191 & 2.0 & .8 & $<30$ & $<10$ \\
\hline 24 & 403659111580501 & $10 / 20 / 1999$ & 124 & 76.38 & 15.0 & 3,050 & 7.0 & 453 & 4.6 & .4 & $<30$ & - \\
\hline 25 & 403652111570201 & $10 / 12 / 1999$ & 68.5 & 44.97 & 17.5 & 2,160 & 7.0 & 361 & 5.4 & .6 & $<30$ & $<10$ \\
\hline $26 \mathrm{D}$ & 403627111495701 & 08/10/1999 & 77.5 & 22.96 & 10.5 & 350 & 7.8 & 85 & 5.3 & 2.3 & - & 10 \\
\hline $26 \mathrm{~S}$ & 403627111495702 & 09/15/1999 & 31.5 & 20.50 & 16.0 & 235 & 7.0 & 68 & 3.7 & .4 & 40 & $<10$ \\
\hline 27 & 403628111514301 & 09/07/1999 & 73.5 & 58.42 & 15.5 & 1,140 & 6.8 & 336 & 6.4 & .4 & 100 & $<10$ \\
\hline 29 & 403638111505101 & 09/21/1999 & 34 & 8.81 & 13.5 & 485 & 7.5 & 192 & .7 & .4 & $<30$ & 100 \\
\hline 30 & 403609111573901 & $10 / 12 / 1999$ & 68.5 & 51.12 & 17.0 & 1,660 & 7.1 & 350 & 6.9 & .2 & $<30$ & $<10$ \\
\hline 31 & 403544111584801 & 10/21/1999 & 154 & 135.17 & 14.5 & 1,370 & 7.6 & 304 & 8.7 & 1.5 & $<30$ & - \\
\hline 32 & 403524111512901 & 09/14/1999 & 88.5 & 75.87 & 14.0 & 710 & 7.3 & 239 & 8.0 & 12 & $<30$ & $<10$ \\
\hline 33 & 403609111573901 & 10/14/1999 & 95.5 & 69.65 & 17.0 & 2,190 & 7.3 & 362 & 6.8 & .1 & $<30$ & $<10$ \\
\hline 34 & 403420111530101 & 090/9/1999 & 77.5 & 56.38 & - & 1,040 & 7.2 & 266 & 5.3 & 1.7 & 50 & 10 \\
\hline 37 & 403316111510601 & 09/08/1999 & 73 & 45.01 & 15.0 & 600 & 7.5 & 176 & 5.8 & 5.6 & 80 & $<10$ \\
\hline 39 & 403244111504701 & 10/04/1999 & 106 & 92.80 & 18.5 & 860 & 7.5 & 298 & 6.2 & .4 & 35 & 10 \\
\hline 41 & 403129111510601 & 09/16/1999 & 23 & 5.27 & 15.5 & 730 & 6.9 & 228 & 3.4 & .8 & 60 & $<10$ \\
\hline
\end{tabular}


Table 7. Concentration of dissolved major ions in water sampled from monitoring wells in Salt Lake Valley, Utah, 1999

[Well identifier corresponds to site shown in figure 3 and listed in table $6 ; \mathrm{mg} / \mathrm{L}$, milligrams per liter; $\mu \mathrm{g} / \mathrm{L}$, micrograms per liter; ${ }^{\circ} \mathrm{C}$, degrees Celsius; number below the parameter name is the U.S. Geological Survey National Water Information System parameter code; <, less than; E, estimated value; M, presence of constituent verified but not quantified]

\begin{tabular}{|c|c|c|c|c|c|c|c|}
\hline $\begin{array}{c}\text { Well } \\
\text { identifier }\end{array}$ & $\begin{array}{c}\text { Bicarbonate } \\
(\mathrm{mg} / \mathrm{L} \text { as } \\
\left.\mathrm{HCO}_{3}\right) \\
(00453)\end{array}$ & $\begin{array}{c}\text { Bromide } \\
\text { (mg/L as Br) } \\
(71870)\end{array}$ & $\begin{array}{l}\text { Calcium } \\
\text { (mg/L as Ca) } \\
\text { (00915) }\end{array}$ & $\begin{array}{c}\text { Chloride } \\
\text { (mg/L as Cl) } \\
(00940)\end{array}$ & $\begin{array}{c}\text { Fluoride } \\
\text { (mg/L as F) } \\
(00950)\end{array}$ & $\begin{array}{c}\text { Iron } \\
(\mu \mathrm{g} / \mathrm{L} \text { as } \mathrm{Fe}) \\
(01046)\end{array}$ & $\begin{array}{c}\text { Magnesium } \\
\text { (mg/L as Mg) } \\
\quad(00925)\end{array}$ \\
\hline 1 & 463 & 0.21 & 60.4 & 105 & 0.6 & 20 & 47.0 \\
\hline 2 & 522 & .40 & 164 & 456 & .7 & $<10$ & 32.4 \\
\hline 3 & 360 & .25 & 89.1 & 191 & .6 & $<10$ & 53.7 \\
\hline 4 & 310 & .10 & 101 & 428 & .8 & 40 & 61.0 \\
\hline 5 & 320 & .22 & 62.7 & 185 & .7 & $<10$ & 42.7 \\
\hline 6 & 804 & .45 & 210 & 382 & .5 & $<10$ & 101 \\
\hline 7 & 385 & .24 & 85.8 & 270 & .9 & 170 & 56.0 \\
\hline 8 & 233 & .11 & 93.5 & 126 & .2 & $<10$ & 27.2 \\
\hline 9 & 458 & .33 & 140 & 275 & 1.1 & $<10$ & 67.1 \\
\hline 10 & 334 & .52 & 226 & 401 & .6 & $<10$ & 141 \\
\hline 11 & 450 & .37 & 104 & 351 & .6 & $<10$ & 95.5 \\
\hline 14 & 400 & .08 & 61.3 & 194 & 1.0 & $<10$ & 29.6 \\
\hline 17 & 564 & .34 & 448 & 276 & .9 & M & 92.3 \\
\hline 18 & 401 & 1.40 & 105 & 131 & .4 & $<10$ & 25.7 \\
\hline 20 & 493 & .23 & 137 & 182 & .5 & $<10$ & 175 \\
\hline 22 & 233 & .05 & 77.9 & 48.6 & .8 & 20 & 26.2 \\
\hline 24 & 557 & .32 & 192 & 322 & .2 & $<30$ & 99.9 \\
\hline 25 & 449 & .32 & 150 & 276 & .2 & $<10$ & 53.5 \\
\hline $26 \mathrm{D}$ & 103 & .02 & 20.6 & 40.8 & .4 & $<10$ & 4.96 \\
\hline $26 \mathrm{~S}$ & 82 & $<.01$ & 25.6 & 13.2 & .2 & $<10$ & 4.88 \\
\hline 27 & 410 & .12 & 128 & 118 & .6 & $\mathrm{M}$ & 37.0 \\
\hline 29 & 238 & .02 & 51.3 & 12.9 & 1.9 & 540 & 22.9 \\
\hline 30 & 427 & .22 & 98.3 & 168 & .4 & $<10$ & 52.0 \\
\hline 31 & 371 & .16 & 54.7 & 188 & .4 & M & 34.9 \\
\hline 32 & 292 & .03 & 89.6 & 48.1 & .6 & M & 25.7 \\
\hline 33 & 442 & .23 & 113 & 230 & .2 & $<10$ & 48.7 \\
\hline 34 & 324 & .10 & 99.8 & 101 & .9 & $<10$ & 30.0 \\
\hline 37 & 215 & .08 & 77.1 & 35.0 & .1 & $\mathrm{M}$ & 21.2 \\
\hline 39 & 363 & .06 & 93.4 & 47.2 & .5 & $<10$ & 25.8 \\
\hline 41 & 279 & .05 & 65.4 & 64.9 & .6 & M & 33.1 \\
\hline
\end{tabular}


Table 7. Concentration of dissolved major ions in water sampled from monitoring wells in Salt Lake Valley, Utah, 1999—Continued

\begin{tabular}{|c|c|c|c|c|c|c|c|}
\hline $\begin{array}{c}\text { Well } \\
\text { identifier }\end{array}$ & $\begin{array}{c}\text { Manganese } \\
\text { ( } \mu \mathrm{g} / \mathrm{L} \text { as } \mathrm{Mn}) \\
(01056)\end{array}$ & $\begin{array}{c}\text { Potassium } \\
\text { (mg/L as K) } \\
(00935)\end{array}$ & $\begin{array}{c}\text { Silica } \\
\underset{\left(\mathrm{mg} / \mathrm{L} \text { as } \mathrm{SiO}_{2}\right)}{(00955)}\end{array}$ & $\begin{array}{c}\text { Sodium } \\
\text { (mg/L as Na) } \\
\text { (00930) }\end{array}$ & $\begin{array}{c}\text { Sulfate } \\
\left.\text { (mg/L as S0})_{4}\right) \\
(00945)\end{array}$ & $\begin{array}{c}\text { Solids, residue } \\
\text { at } 180^{\circ} \mathrm{C} \\
(\mathrm{mg} / \mathrm{L}) \\
(70300)\end{array}$ & $\begin{array}{c}\text { Solids, sum of } \\
\text { constituents } \\
\text { (mg/L) } \\
(70301)\end{array}$ \\
\hline 1 & 148 & 18.4 & 39.4 & 157 & 139 & 804 & 829 \\
\hline 2 & $<2.2$ & 21.9 & 37.2 & 267 & 353 & 1,800 & 1,620 \\
\hline 3 & 2.2 & 14.4 & 38.4 & 154 & 218 & 982 & 974 \\
\hline 4 & 44.8 & 11.7 & 40.3 & 212 & 134 & 1,190 & 1,150 \\
\hline 5 & $<2.2$ & 9.69 & 42.8 & 162 & 143 & 818 & 838 \\
\hline 6 & 38.4 & 33.8 & 40.2 & 263 & 361 & 1,850 & 1,810 \\
\hline 7 & 49.5 & 19.3 & 37.3 & 189 & 209 & 1,080 & 1,080 \\
\hline 8 & 2.9 & 4.74 & 37.2 & 75.8 & 110 & 636 & 619 \\
\hline 9 & 8.0 & 31.4 & 28.5 & 213 & 394 & 1,410 & 1,390 \\
\hline 10 & $<2.2$ & 21.9 & 47.6 & 241 & 816 & 2,200 & 2,100 \\
\hline 11 & 12.4 & 23.2 & 47.0 & 195 & 208 & 1,300 & 1,300 \\
\hline 14 & 3.6 & 17.4 & 46.3 & 190 & 101 & 848 & 874 \\
\hline 17 & 36.9 & 50.0 & 49.9 & 228 & 1,210 & 2,820 & 2,690 \\
\hline 18 & E1.5 & 6.06 & 16.6 & 82.9 & 49.0 & 618 & 635 \\
\hline 20 & 40.5 & 57.8 & 51.6 & 473 & 1,480 & 2,910 & 2,830 \\
\hline 22 & 25.5 & 4.64 & 15.4 & 14.8 & 64.4 & 381 & 386 \\
\hline 24 & 12 & 14.4 & 39.8 & 338 & 749 & 2,180 & 2,030 \\
\hline 25 & 2.9 & 14.2 & 36.9 & 246 & 378 & 1,440 & 1,410 \\
\hline $26 \mathrm{D}$ & E1.8 & 1.35 & 6.5 & 38.1 & 16.9 & 189 & 181 \\
\hline $26 \mathrm{~S}$ & E1.4 & 1.56 & 6.6 & 12.6 & 24.3 & 134 & 131 \\
\hline 27 & E1.7 & 7.52 & 22.1 & 67.8 & 80.0 & 718 & 696 \\
\hline 29 & 110 & 4.46 & 18.3 & 10.3 & 31.4 & 282 & 271 \\
\hline 30 & 10.3 & 10.3 & 26.6 & 179 & 263 & 1,060 & 1,040 \\
\hline 31 & 65.2 & 10.9 & 25.3 & 163 & 94.2 & 806 & 797 \\
\hline 32 & 2.4 & 4.34 & 17.0 & 15.2 & 41.4 & 405 & 414 \\
\hline 33 & $<2.2$ & 7.72 & 41.8 & 322 & 505 & 1,510 & 1,500 \\
\hline 34 & $<2.2$ & 7.21 & 30.3 & 65.8 & 85.4 & 626 & 614 \\
\hline 37 & 10.4 & 4.63 & 15.7 & 16.7 & 42.3 & 383 & 378 \\
\hline 39 & 18.7 & 5.76 & 20.8 & 53.7 & 64.4 & 521 & 534 \\
\hline 41 & $<2.2$ & 5.43 & 18.2 & 40.0 & 40.9 & 445 & 426 \\
\hline
\end{tabular}


Table 8. Concentration of trace elements in water sampled from monitoring wells in Salt Lake Valley, Utah, 1999

[Well identifier corresponds to site shown in figure 3 and listed in table 6; water samples for Radon-222 analysis were not filtered; $\mu \mathrm{g} / \mathrm{L}$, micrograms per liter; pCi/L, picocuries per liter; number below the parameter name is the U.S. Geological Survey National Water Information System parameter code; <, less than; E, estimated value]

\begin{tabular}{|c|c|c|c|c|c|c|c|c|c|}
\hline $\begin{array}{c}\text { Well } \\
\text { identifier }\end{array}$ & $\begin{array}{c}\text { Dissolved } \\
\text { aluminum } \\
(\mu \mathrm{g} / \mathrm{L} \text { as } \mathrm{Al}) \\
(01106)\end{array}$ & $\begin{array}{c}\text { Dissolved } \\
\text { antimony } \\
\text { ( } \mu \mathrm{g} / \mathrm{L} \text { as } \mathrm{Sb}) \\
(01095)\end{array}$ & $\begin{array}{c}\text { Dissolved } \\
\text { arsenic } \\
\text { ( } \mu \mathrm{g} / \mathrm{L} \text { as } \mathrm{As}) \\
(01000)\end{array}$ & $\begin{array}{c}\text { Dissolved } \\
\text { barium } \\
\text { ( } \mu \mathrm{g} / \mathrm{L} \text { as Ba) } \\
(01005)\end{array}$ & $\begin{array}{c}\text { Dissolved } \\
\text { beryllium } \\
\text { ( } \mu \mathrm{g} / \mathrm{L} \text { as Be) } \\
(01010)\end{array}$ & $\begin{array}{c}\text { Dissolved } \\
\text { cadmium } \\
\text { ( } \mu \mathrm{g} / \mathrm{L} \text { as } \mathrm{Cd}) \\
(01025)\end{array}$ & $\begin{array}{c}\text { Dissolved } \\
\text { chromium } \\
(\mu \mathrm{g} / \mathrm{L} \text { as } \mathrm{Cr}) \\
(01030)\end{array}$ & $\begin{array}{c}\text { Dissolved } \\
\text { cobalt } \\
\text { ( } \mu \mathrm{g} / \mathrm{L} \text { as Co) } \\
(01035)\end{array}$ & $\begin{array}{c}\text { Dissolved } \\
\text { copper } \\
\text { ( } \mu \mathrm{g} / \mathrm{L} \text { as } \mathrm{Cu}) \\
(01040)\end{array}$ \\
\hline 1 & 2 & $<1.00$ & 9.9 & 62.7 & $<1.00$ & $<1.00$ & 0.9 & $<1.00$ & 1.1 \\
\hline 2 & 1 & $<1.00$ & 10.2 & 36.6 & $<1.00$ & $<1.00$ & 2.9 & $<1.00$ & 3.0 \\
\hline 3 & 3 & $<1.00$ & 12.2 & 28.3 & $<1.00$ & $<1.00$ & E.7 & $<1.00$ & 1.3 \\
\hline 4 & $<1$ & $<1.00$ & 19.6 & 74.2 & $<1.00$ & $<1.00$ & 1.9 & $<1.00$ & 1.1 \\
\hline 5 & 1 & $<1.00$ & 13.7 & 33.9 & $<1.00$ & $<1.00$ & 2.7 & $<1.00$ & 1.3 \\
\hline 6 & 2 & $<1.00$ & 14.5 & 39.6 & $<1.00$ & $<1.00$ & E.5 & $<1.00$ & 3.9 \\
\hline 7 & 1 & $<1.00$ & 11.7 & 36.3 & $<1.00$ & $<1.00$ & 1.0 & $<1.00$ & 1.2 \\
\hline 8 & 3 & $<1.00$ & 13.9 & 53.1 & $<1.00$ & $<1.00$ & 1.7 & $<1.00$ & $<1.0$ \\
\hline 9 & 1 & $<1.00$ & 2.1 & 24.7 & $<1.00$ & $<1.00$ & 3.5 & $<1.00$ & 2.3 \\
\hline 10 & 5 & $<1.00$ & 13.4 & 19.5 & $<1.00$ & $<1.00$ & 2.6 & $<1.00$ & 4.9 \\
\hline 11 & $<1$ & $<1.00$ & 11.2 & 35.1 & $<1.00$ & $<1.00$ & E.7 & $<1.00$ & 1.9 \\
\hline 14 & $<1$ & $<1.00$ & 15.4 & 98.8 & $<1.00$ & $<1.00$ & .8 & $<1.00$ & 1.7 \\
\hline 17 & 1 & $<1.00$ & 7.0 & 47.7 & $<1.00$ & $<1.00$ & $<1.0$ & 1.05 & 10 \\
\hline 18 & 1 & $<1.00$ & $<1.0$ & 202 & $<1.00$ & $<1.00$ & 1.2 & $<1.00$ & 2.3 \\
\hline 20 & 1 & $<1.00$ & 17.7 & 11.8 & $<1.00$ & $<1.00$ & .9 & 1.09 & 6.7 \\
\hline 22 & 2 & $<1.00$ & $<2.0$ & 142 & $<1.00$ & $<1.00$ & $<.8$ & $<1.00$ & $<1.0$ \\
\hline 24 & 3 & $<1.00$ & 7.3 & 20.3 & $<1.00$ & $<1.00$ & 3.1 & $<1.00$ & 2.7 \\
\hline 25 & $<1$ & $<1.00$ & 12.5 & 17.5 & $<1.00$ & $<1.00$ & 2.9 & $<1.00$ & 6.1 \\
\hline $26 \mathrm{D}$ & 10 & 1.69 & $<1.0$ & 51.7 & $<1.00$ & $<1.00$ & $<1.0$ & $<1.00$ & $<1.0$ \\
\hline $26 \mathrm{~S}$ & 2 & 1.30 & 2.0 & 71.4 & $<1.00$ & $<1.00$ & $<1.0$ & $<1.00$ & 1.0 \\
\hline 27 & 1 & $<1.00$ & 1.3 & 140 & $<1.00$ & $<1.00$ & 2.5 & $<1.00$ & 2.3 \\
\hline 29 & 2 & $<1.00$ & 5.6 & 81.1 & $<1.00$ & $<1.00$ & $<.8$ & $<1.00$ & $<1.0$ \\
\hline 30 & $<1$ & $<1.00$ & 7.3 & 39.6 & $<1.00$ & $<1.00$ & 2.2 & $<1.00$ & 3.5 \\
\hline 31 & 3 & $<1.00$ & 6.3 & 95.0 & $<1.00$ & $<1.00$ & 4.7 & $<1.00$ & 1.5 \\
\hline 32 & 2 & $<1.00$ & $<1.0$ & 209 & $<1.00$ & $<1.00$ & 1.4 & $<1.00$ & 2.4 \\
\hline 33 & $<1$ & $<1.00$ & 10.8 & 14.7 & $<1.00$ & $<1.00$ & 3.4 & $<1.00$ & 3.5 \\
\hline 34 & 2 & $<1.00$ & $<1.0$ & 112 & $<1.00$ & $<1.00$ & $<1.0$ & $<1.00$ & 2.1 \\
\hline 37 & 3 & $<1.00$ & 1.1 & 255 & $<1.00$ & $<1.00$ & 1.7 & $<1.00$ & 1.3 \\
\hline 39 & 2 & $<1.00$ & 3.3 & 130 & $<1.00$ & $<1.00$ & 1.5 & $<1.00$ & 2.3 \\
\hline 41 & 1 & $<1.00$ & $<1.0$ & 150 & $<1.00$ & $<1.00$ & $<1.0$ & $<1.00$ & 1.6 \\
\hline
\end{tabular}


Table 8. Concentration of trace elements in water sampled from monitoring wells in Salt Lake Valley, Utah, 1999_Continued

\begin{tabular}{|c|c|c|c|c|c|c|c|c|c|}
\hline $\begin{array}{c}\text { Well } \\
\text { identifier }\end{array}$ & $\begin{array}{c}\text { Dissolved } \\
\text { lead } \\
\text { ( } \mu \mathrm{g} / \mathrm{L} \text { as } \mathrm{Pb}) \\
(01049)\end{array}$ & $\begin{array}{c}\text { Dissolved } \\
\text { molybdenum } \\
\text { ( } \mu \mathrm{g} / \mathrm{L} \text { as Mo) } \\
(01060)\end{array}$ & $\begin{array}{c}\text { Dissolved } \\
\text { nickel } \\
(\mu \mathrm{g} / \mathrm{L} \text { as } \mathrm{Ni}) \\
(01065)\end{array}$ & $\begin{array}{c}\text { Total } \\
\text { radon-222 } \\
(\mathrm{pCi} / \mathrm{L}) \\
(\mathbf{8 2 3 0 3 )}\end{array}$ & $\begin{array}{c}\text { Radon-222 } \\
\text { 2-sigma }{ }^{1} \\
\text { (pCi/L) } \\
(76002)\end{array}$ & $\begin{array}{c}\text { Dissolved } \\
\text { selenium } \\
\text { ( } \mu \mathrm{g} / \mathrm{L} \text { as } \mathrm{Se}) \\
(01145)\end{array}$ & $\begin{array}{c}\text { Dissolved } \\
\text { silver } \\
\text { ( } \mu \mathrm{g} / \mathrm{L} \text { as } \mathrm{Ag}) \\
(01075)\end{array}$ & $\begin{array}{c}\text { Dissolved } \\
\text { uranium } \\
(\mu \mathrm{g} / \mathrm{L} \text { as } \mathrm{U}) \\
(22703)\end{array}$ & $\begin{array}{c}\text { Dissolved } \\
\text { zinc } \\
\text { ( } \mu \mathrm{g} / \mathrm{L} \text { as } \mathrm{Zn}) \\
(01090)\end{array}$ \\
\hline 1 & $<1.00$ & 8.1 & 2.56 & 700 & 26 & 1.2 & $<1.0$ & 8.11 & 1 \\
\hline 2 & $<1.00$ & 99.1 & 2.17 & 589 & 23 & 2.1 & $<2.0$ & 16.2 & 4 \\
\hline 3 & $<1.00$ & 5.0 & 1.83 & 243 & 18 & 2.6 & $<1.0$ & 5.29 & 2 \\
\hline 4 & $<1.00$ & 5.5 & 3.91 & 514 & 23 & $<1.0$ & $<1.0$ & 4.70 & 3 \\
\hline 5 & $<1.00$ & 4.3 & 1.37 & 503 & 27 & 2.5 & $<1.0$ & 4.44 & 2 \\
\hline 6 & $<1.00$ & 19.4 & 4.74 & 404 & 22 & $<2.4$ & $<1.0$ & 16.0 & 3 \\
\hline 7 & $<1.00$ & 8.3 & 1.95 & 400 & 21 & E1.5 & $<1.0$ & 7.10 & $<1$ \\
\hline 8 & $<1.00$ & $<1.0$ & 2.96 & 485 & 23 & $<2.4$ & $<1.0$ & 2.60 & 2 \\
\hline 9 & $<1.00$ & 55.7 & 2.61 & 506 & 24 & 4.0 & $<1.0$ & 22.3 & 2 \\
\hline 10 & $<1.00$ & 11.1 & 5.15 & 559 & 24 & 13.0 & $<1.0$ & 13.5 & 6 \\
\hline 11 & $<1.00$ & 2.7 & 1.97 & 297 & 20 & $<2.4$ & $<1.0$ & 10.9 & 2 \\
\hline 14 & $<1.00$ & 6.9 & 2.50 & 524 & 24 & 2.6 & $<1.0$ & 11.5 & 3 \\
\hline 17 & $<1.00$ & 45.4 & 7.88 & 825 & 27 & 1.7 & $<1.0$ & 26.6 & 6 \\
\hline 18 & $<1.00$ & 3.9 & 2.34 & 522 & 23 & $<1.0$ & $<1.0$ & 8.01 & 3 \\
\hline 20 & $<1.00$ & 2.5 & 3.68 & 678 & 26 & 4.2 & $<1.0$ & 8.62 & 8 \\
\hline 22 & $<1.00$ & 27.8 & 1.30 & 1,250 & 33 & 3.0 & $<1.0$ & 38.9 & 3 \\
\hline 24 & $<1.00$ & $<1.0$ & 3.69 & 535 & 24 & E3.0 & $<1.0$ & 13.9 & 4 \\
\hline 25 & $<1.00$ & 4.3 & 4.19 & 810 & 27 & 3.0 & $<1.0$ & 12.4 & 4 \\
\hline $26 \mathrm{D}$ & $<1.00$ & 8.1 & 5.42 & 658 & 25 & $<1.0$ & $<1.0$ & 4.74 & $<1$ \\
\hline $26 \mathrm{~S}$ & $<1.00$ & 4.3 & $<1.00$ & 641 & 24 & $<1.0$ & $<1.0$ & 1.50 & 1 \\
\hline 27 & $<1.00$ & 3.0 & 5.81 & 920 & 28 & $<1.0$ & $<1.0$ & 5.16 & 1 \\
\hline 29 & $<1.00$ & 95.2 & $<1.00$ & 719 & 26 & $<1.0$ & $<1.0$ & $<1.00$ & $<1$ \\
\hline 30 & $<1.00$ & 4.1 & 3.01 & 352 & 20 & 3.6 & $<1.0$ & 10.4 & 4 \\
\hline 31 & $<1.00$ & 10.2 & 5.82 & 679 & 27 & $<2.4$ & $<1.0$ & 2.68 & 6 \\
\hline 32 & $<1.00$ & 2.0 & 4.03 & 1,170 & 32 & $<1.0$ & $<1.0$ & 22.8 & 2 \\
\hline 33 & $<1.00$ & 1.6 & 2.97 & 635 & 25 & 2.6 & $<1.0$ & 8.89 & 3 \\
\hline 34 & $<1.00$ & 7.5 & 3.39 & 491 & 31 & $<1.0$ & $<1.0$ & 36.2 & 5 \\
\hline 37 & $<1.00$ & 1.5 & 3.29 & 2,190 & 42 & $<1.0$ & $<1.0$ & 8.04 & 2 \\
\hline 39 & $<1.00$ & 3.4 & 3.24 & 462 & 22 & $<2.4$ & $<1.0$ & 21.2 & 2 \\
\hline 41 & $<1.00$ & 2.8 & 1.43 & 1,130 & 31 & $<1.0$ & $<1.0$ & 92.7 & 2 \\
\hline
\end{tabular}


Table 9. Concentration of nutrient constituents and organic carbon in water sampled from monitoring wells in Salt Lake Valley, Utah, 1999

[Well identifier corresponds to site shown in figure 3 and listed in table 6; $\mathrm{mg} / \mathrm{L}$, milligrams per liter; number below the parameter name is the U.S. Geological Survey National Water Information System parameter code; <, less than; E, estimated value]

\begin{tabular}{|c|c|c|c|c|c|c|c|}
\hline $\begin{array}{c}\text { Well } \\
\text { identifier }\end{array}$ & $\begin{array}{c}\text { Dissolved } \\
\text { ammonia } \\
\text { (mg/L as N) } \\
\text { (00608) }\end{array}$ & $\begin{array}{c}\text { Dissolved } \\
\text { ammonia plus } \\
\text { organic nitrogen } \\
\text { (mg/L as N) } \\
\text { (00623) }\end{array}$ & $\begin{array}{c}\text { Dissolved } \\
\text { organic } \\
\text { carbon } \\
\text { (mg/L as C) } \\
\text { (00681) }\end{array}$ & $\begin{array}{c}\text { Dissolved } \\
\text { nitrite } \\
\text { (mg/L as N) } \\
\text { (00613) }\end{array}$ & $\begin{array}{c}\text { Dissolved } \\
\text { nitrite plus } \\
\text { nitrate } \\
\text { (mg/L as N) } \\
\text { (00631) }\end{array}$ & $\begin{array}{c}\text { Dissolved } \\
\text { phosphorus } \\
\text { (mg/L as P) } \\
\text { (00666) }\end{array}$ & $\begin{array}{c}\text { Dissolved } \\
\text { orthophosphorus } \\
\text { (mg/L as } \mathrm{P}) \\
\text { (00671) }\end{array}$ \\
\hline 1 & $<0.020$ & 0.15 & 4.6 & 0.019 & 7.66 & .036 & .034 \\
\hline 2 & $<.020$ & .32 & 2.0 & $<.010$ & 7.35 & .074 & .063 \\
\hline 3 & $<.020$ & .14 & E1.1 & $<.010$ & 8.55 & .028 & .028 \\
\hline 4 & .030 & .14 & 3.2 & .012 & 2.37 & .031 & .025 \\
\hline 5 & $<.020$ & E.08 & .86 & $<.010$ & 7.05 & .024 & .032 \\
\hline 6 & $<.020$ & .34 & E4.5 & $<.010$ & 5.46 & .089 & .084 \\
\hline 7 & $<.020$ & .15 & 1.3 & $<.010$ & 4.72 & .017 & .019 \\
\hline 8 & $<.020$ & E.08 & E.79 & $<.010$ & 6.67 & .033 & .031 \\
\hline 9 & $<.020$ & $<.10$ & 1.3 & $<.010$ & 3.55 & .029 & .033 \\
\hline 10 & .029 & .15 & 1.1 & $<.010$ & 9.78 & .033 & .028 \\
\hline 11 & $<.020$ & .17 & 1.8 & $<.010$ & 12.0 & .029 & .028 \\
\hline 14 & $<.020$ & .18 & 1.9 & .100 & 8.15 & .067 & .064 \\
\hline 17 & $<.020$ & .33 & 3.2 & .107 & 12.7 & .179 & .162 \\
\hline 18 & $<.020$ & .12 & 1.5 & $<.010$ & 4.35 & .013 & .019 \\
\hline 20 & .021 & .15 & 2.1 & $<.010$ & 6.85 & .051 & .056 \\
\hline 22 & $<.020$ & E.06 & .71 & $<.010$ & 4.14 & .006 & $<.010$ \\
\hline 24 & $<.020$ & .24 & E1.5 & $<.010$ & 1.38 & .065 & .060 \\
\hline 25 & .031 & .13 & 1.4 & $<.010$ & 7.20 & .058 & .050 \\
\hline $26 \mathrm{D}$ & $<.020$ & $<.10$ & 1.3 & $<.010$ & .246 & $<.004$ & $<.010$ \\
\hline $26 \mathrm{~S}$ & $<.020$ & $<.10$ & .60 & $<.010$ & .200 & .154 & .133 \\
\hline 27 & $<.020$ & .14 & 1.9 & $<.010$ & 7.50 & .013 & .016 \\
\hline 29 & .043 & E.07 & .80 & $<.010$ & $<.050$ & .022 & .023 \\
\hline 30 & .023 & .13 & 1.5 & $<.010$ & 6.81 & .037 & .028 \\
\hline 31 & $<.020$ & .12 & .72 & $<.010$ & 9.49 & .027 & .024 \\
\hline 32 & $<.020$ & .22 & 2.0 & $<.010$ & 6.39 & .006 & $<.010$ \\
\hline 33 & .022 & .14 & 1.5 & $<.010$ & 3.94 & .058 & .049 \\
\hline 34 & $<.020$ & .12 & 1.9 & $<.010$ & 7.71 & .011 & .015 \\
\hline 37 & $<.020$ & E.07 & 1.1 & $<.010$ & 13.3 & .191 & .172 \\
\hline 39 & $<.020$ & .22 & 2.0 & .012 & 9.96 & .029 & .027 \\
\hline 41 & $<.020$ & .13 & 1.5 & $<.010$ & 4.45 & .207 & .189 \\
\hline
\end{tabular}


Table 10. Pesticides and degradation products analyzed for in water sampled from monitoring wells in Salt Lake Valley, Utah, 1999

[Parameter code is used in U.S. Geological Survey National Water Information System database; $\mu \mathrm{g} / \mathrm{L}$, micrograms per liter; —, no number]

\begin{tabular}{cccc}
\hline & & Chemical & \\
Compound & Parameter & Abstracts & Minimum \\
& code & $\begin{array}{c}\text { Service } \\
\text { registry } \\
\text { number }\end{array}$ & $\begin{array}{c}\text { reporting level } \\
(\mu \mathrm{g} / \mathrm{L})\end{array}$ \\
& &
\end{tabular}

\begin{tabular}{|c|c|c|c|}
\hline \multicolumn{4}{|c|}{ Gas Chromatography/Mass Spectrometry analytical method } \\
\hline Acetochlor & 49260 & $34256-82-1$ & 0.002 \\
\hline Alachlor & 46342 & $15972-60-8$ & .002 \\
\hline alpha-HCH & 34253 & 319-84-6 & .002 \\
\hline Atrazine & 39632 & $1912-24-9$ & .001 \\
\hline Azinphos-methyl & 82686 & $86-50-0$ & .001 \\
\hline Benfluralin & 82673 & $1861-40-1$ & .002 \\
\hline Butylate & 04028 & $2008-41-5$ & .002 \\
\hline Carbaryl & 82680 & $63-25-2$ & .003 \\
\hline Carbofuran & 82674 & $1563-66-2$ & .003 \\
\hline Chlorpyrifos & 38933 & 2921-88-2 & .004 \\
\hline cis-Permethrin & 82687 & $54774-45-7$ & .005 \\
\hline Cyanazine & 04041 & $21725-46-2$ & .004 \\
\hline Dacthal & 82682 & 1861-32-1 & .002 \\
\hline Deethylatrazine & 04040 & 6190-65-4 & .002 \\
\hline Diazinon & 39572 & $333-41-5$ & .002 \\
\hline Dieldrin & 39381 & $60-57-1$ & .001 \\
\hline 2,6-Diethylaniline & 82660 & $579-66-8$ & .003 \\
\hline Disulfoton & 82677 & 298-04-4 & .017 \\
\hline EPTC & 82668 & 759-94-4 & .002 \\
\hline Ethalfluralin & 82663 & $55283-68-6$ & .004 \\
\hline Ethoprophos & 82672 & $13194-48-4$ & .003 \\
\hline Fonofos & 04095 & 944-22-9 & .003 \\
\hline Lindane & 39341 & 58-89-9 & .004 \\
\hline Linuron & 82666 & $330-55-2$ & .002 \\
\hline Malathion & 39532 & 121-75-5 & .005 \\
\hline Metolachlor & 39415 & $51218-45-2$ & .002 \\
\hline Metribuzin & 82630 & 21087-64-9 & .004 \\
\hline Molinate & 82671 & 2212-67-1 & .004 \\
\hline Napropamide & 82684 & $15299-99-7$ & .003 \\
\hline p,p'-DDE & 34653 & 72-55-9 & .006 \\
\hline Parathion & 39542 & $56-38-2$ & .004 \\
\hline Parathion-methyl & 82667 & 298-00-0 & .006 \\
\hline Pebulate & 82669 & 1114-71-2 & .004 \\
\hline Pendimethalin & 82683 & $40487-42-1$ & .004 \\
\hline Phorate & 82664 & 298-02-2 & .002 \\
\hline Prometon & 04037 & $1610-18-0$ & .018 \\
\hline Propachlor & 04024 & 1918-16-7 & .007 \\
\hline Propanil & 82679 & 709-98-8 & .004 \\
\hline Propargite & 82685 & $2312-35-8$ & .013 \\
\hline Propyzamide & 82676 & $23950-58-5$ & .003 \\
\hline Simazine & 04035 & 122-34-9 & .005 \\
\hline Tebuthiuron & 82670 & $34014-18-1$ & .010 \\
\hline Terbacil & 82665 & $5902-51-2$ & .007 \\
\hline Terbufos & 82675 & $13071-79-9$ & .013 \\
\hline Thiobencarb & 82681 & $28249-77-6$ & .002 \\
\hline Triallate & 82678 & 2303-17-5 & .001 \\
\hline Trifluralin & 82661 & $1582-09-8$ & .002 \\
\hline
\end{tabular}

\begin{tabular}{|c|c|c|c|}
\hline Compound & $\begin{array}{l}\text { Parameter } \\
\text { code }\end{array}$ & $\begin{array}{c}\text { Chemical } \\
\text { Abstracts } \\
\text { Service } \\
\text { registry } \\
\text { number }\end{array}$ & $\begin{array}{c}\text { Minimum } \\
\text { reporting level } \\
(\mu \mathrm{g} / \mathrm{L})\end{array}$ \\
\hline \multicolumn{4}{|c|}{ High-Performance Liquid Chromatography analytical method ${ }^{1}$} \\
\hline $2,4-\mathrm{D}$ & 39732 & $94-75-7$ & .08 \\
\hline 2,4-D methyl ester & 50470 & $1928-38-7$ & .086 \\
\hline 2,4-DB & 38746 & $94-82-6$ & .05 \\
\hline 2-Hydroxyatrazine & 50355 & $2163-68-0$ & .193 \\
\hline $\begin{array}{l}\text { 3(4-Chlorophenyl)-1- } \\
\text { methyl urea }\end{array}$ & 61692 & $5352-88-5$ & .0915 \\
\hline 3-Hydroxycarbofuran & 49308 & $16655-82-6$ & .062 \\
\hline 3-Ketocarbofuran & 50295 & $16709-30-1$ & .072 \\
\hline Acifluorfen & 49315 & $50594-66-6$ & .06 \\
\hline Aldicarb & 49312 & 116-06-3 & .08 \\
\hline Aldicarb sulfone & 49313 & $1646-88-4$ & .16 \\
\hline Aldicarb sulfoxide & 49314 & $1646-87-3$ & .03 \\
\hline Atrazine & 39632 & 1912-24-9 & .074 \\
\hline Bendiocarb & 50299 & $22781-23-3$ & .061 \\
\hline Benomyl & 50300 & $17804-35-2$ & .022 \\
\hline Bensulfuron-methyl & 61693 & $83055-99-6$ & .0482 \\
\hline Bentazon & 38711 & $25057-89-0$ & .02 \\
\hline Bromacil & 04029 & $314-40-9$ & .08 \\
\hline Bromoxynil & 49311 & $1689-84-5$ & .06 \\
\hline Caffeine & 50305 & 58-08-2 & .081 \\
\hline Carbaryl & 49310 & $63-25-2$ & .06 \\
\hline Carbofuran & 49309 & $1563-66-2$ & .06 \\
\hline Chloramben, methyl ester & 61188 & $7286-84-2$ & .11 \\
\hline Chlorimuron-ethyl & 50306 & $90982-32-4$ & .037 \\
\hline Chlorothalonil & 49306 & $1897-45-6$ & .05 \\
\hline Clopyralid & 49305 & $1702-17-6$ & .04 \\
\hline Cycloate & 04031 & $1134-23-2$ & .05 \\
\hline Dacthal monoacid & 49304 & $887-54-7$ & .07 \\
\hline Deethylatrazine & 04040 & $6190-65-4$ & .087 \\
\hline Deethyldeisopropylatrazine & 04039 & $3397-62-4$ & .06 \\
\hline Deisopropylatrazine & 04038 & $1007-28-9$ & .07 \\
\hline Dicamba & 38442 & 1918-00-9 & .10 \\
\hline Dichlorprop & 49302 & $120-36-5$ & .05 \\
\hline Dinoseb & 49301 & $88-85-7$ & .04 \\
\hline Diphenamid & 04033 & $957-51-7$ & .06 \\
\hline Diuron & 49300 & $330-54-1$ & .08 \\
\hline Fenuron & 49297 & $101-42-8$ & .07 \\
\hline Flumetsulam & 61694 & $98967-40-9$ & .0866 \\
\hline Fluometuron & 38811 & $2164-17-2$ & .06 \\
\hline Imazaquin & 50356 & $81335-37-7$ & .103 \\
\hline Imazethapyr & 50407 & $81335-77-5$ & .088 \\
\hline Imidacloprid & 61695 & 138261-41-3 & .106 \\
\hline Linuron & 38478 & $330-55-2$ & .07 \\
\hline МCPA & 38482 & 94-74-6 & .06 \\
\hline МСРВ & 38487 & 94-81-5 & .062 \\
\hline Metalaxyl & 50359 & $57837-19-1$ & .057 \\
\hline Methiocarb & 38501 & $2032-65-7$ & .08 \\
\hline Methomyl & 49296 & $16752-77-5$ & .08 \\
\hline Methomyl Oxime & 61696 & - & .0102 \\
\hline
\end{tabular}


Table 10. Pesticides and degradation products analyzed for in water sampled from monitoring wells in Salt Lake Valley, Utah, 1999—Continued

\begin{tabular}{|c|c|c|c|}
\hline Compound & $\begin{array}{l}\text { Parameter } \\
\text { code }\end{array}$ & $\begin{array}{c}\text { Chemical } \\
\text { Abstracts } \\
\text { Service } \\
\text { registry } \\
\text { number }\end{array}$ & $\begin{array}{c}\text { Minimum } \\
\text { reporting level } \\
(\mu \mathrm{g} / \mathrm{L})\end{array}$ \\
\hline \multicolumn{4}{|c|}{$\begin{array}{c}\text { High-Performance Liquid Chromatography analytical method }{ }^{1}- \\
\text { Continued }\end{array}$} \\
\hline Metsulfuron methyl & 61697 & $74223-64-6$ & .114 \\
\hline Neburon & 49294 & $555-37-3$ & .07 \\
\hline Nicosulfuron & 50364 & 111991-09-4 & .065 \\
\hline Norflurazon & 49293 & $27314-13-2$ & .08 \\
\hline Oryzalin & 49292 & 19044-88-3 & .07 \\
\hline Oxamyl & 38866 & $23135-22-0$ & .02 \\
\hline Oxamyl Oxime & 38866 & - & .064 \\
\hline Picloram & 49291 & $2 / 1 / 1918$ & .07 \\
\hline Propham & 49236 & $122-42-9$ & .07 \\
\hline Propiconazole & 50471 & 60207-90-1 & .064 \\
\hline Propoxur & 38538 & 114-26-1 & .06 \\
\hline Siduron & 38548 & $1982-49-6$ & .093 \\
\hline Sulfometuron-methyl & 50337 & $74222-97-2$ & .039 \\
\hline Tebuthiuron & 82670 & $34014-18-1$ & .010 \\
\hline Terbacil & 04032 & $5902-51-2$ & .10 \\
\hline Tribenuron-methyl & 61159 & $101200-48-0$ & .07 \\
\hline Triclopyr & 49235 & $55335-06-3$ & .10 \\
\hline \multicolumn{4}{|c|}{$\begin{array}{l}\text { The samples from this study were analyzed by the high-performance } \\
\text { liquid chromatography/mass spectrometry method before its final } \\
\text { approval by the U.S. Geological Survey Office of Water Quality in } \\
\text { 2001. Although the analytical method did not change following } \\
\text { approval, data analyzed before method approval are considered } \\
\text { provisional. Ninety percent of the ground-water samples analyzed } \\
\text { with this method in this study exceeded the recommended 4-day } \\
\text { holding time prior to sample extraction (Furlong and others, 2001). } \\
\text { Degradation of pesticides during extended sample storage is likely, } \\
\text { and concentrations and detection frequencies for the pesticides } \\
\text { analyzed by this method may be biased low. }\end{array}$} \\
\hline
\end{tabular}


Appendix 55 
Table 11. Concentration of dissolved pesticides detected in water sampled from monitoring wells in Salt Lake Valley, Utah, 1999

[Well identifier corresponds to site shown in figure 3 and listed in table 6; number below the parameter name is the U.S. Geological Survey National Water Information System parameter code; concentration reported in micrograms per liter; E, estimated value; <, less than; M, presence of compound verified but not quantified]

\begin{tabular}{|c|c|c|c|c|c|c|c|c|c|}
\hline $\begin{array}{c}\text { Well } \\
\text { identifier }\end{array}$ & $\begin{array}{c}\text { Atrazine } \\
\text { (39632) }\end{array}$ & $\begin{array}{c}\text { Deethyl- } \\
\text { atrazine } \\
(04040)\end{array}$ & $\begin{array}{c}\text { Deethyl- } \\
\text { deisopropyl- } \\
\text { atrazine }{ }^{1} \\
\text { (04039) }\end{array}$ & $\begin{array}{c}\text { Deisopropyl- } \\
\text { atrazine }^{1} \\
(04038)\end{array}$ & $\begin{array}{l}\text { 2-Hydroxy- } \\
\text { atrazine }^{1} \\
(50355)\end{array}$ & $\begin{array}{c}\text { Bromacil }^{1} \\
\text { (04029) }\end{array}$ & $\begin{array}{c}\text { Caffeine }^{1} \\
(50305)\end{array}$ & $\begin{array}{c}\text { Cycloate }^{1,2} \\
\text { (04031) }\end{array}$ & $\begin{array}{c}\text { Diazinon } \\
\text { (39572) }\end{array}$ \\
\hline 1 & 0.196 & E0.025 & E0.01 & $<0.07$ & E0.044 & $<0.08$ & $<0.081$ & $<0.05$ & $<0.002$ \\
\hline 2 & .208 & E.059 & E.01 & $<.07$ & E.052 & $<.08$ & $<.081$ & $<.05$ & $<.002$ \\
\hline 3 & .049 & E.011 & E.01 & $<.07$ & $<.193$ & $<.08$ & $<.081$ & $<.05$ & $<.002$ \\
\hline 4 & .880 & E.307 & .06 & E.03 & E.203 & $<.08$ & $<.081$ & $<.05$ & $<.002$ \\
\hline 5 & .232 & E.136 & E.01 & $<.07$ & E.055 & $<.08$ & $<.081$ & E.04 & $<.002$ \\
\hline 6 & .062 & E.048 & E.01 & $<.07$ & $<.193$ & $<.08$ & $<.081$ & $<.05$ & $<.002$ \\
\hline 7 & .382 & E.061 & E.03 & E.02 & E.096 & .19 & $<.081$ & E.03 & $<.002$ \\
\hline 8 & .023 & E.024 & $\mathrm{M}$ & $<.07$ & $<.193$ & $<.08$ & $<.081$ & $<.05$ & $<.002$ \\
\hline 9 & .188 & E.046 & E.01 & $<.07$ & E.064 & $<.08$ & $<.081$ & E.04 & $<.002$ \\
\hline 10 & .033 & E.008 & $<.06$ & $<.07$ & $<.193$ & $<.08$ & $<.081$ & $<.05$ & $<.002$ \\
\hline 11 & 1.58 & E. 320 & E.12 & E.01 & E.511 & $<.08$ & $<.081$ & $<.05$ & $<.002$ \\
\hline 14 & $<.001$ & E.004 & $<.06$ & $<.07$ & $<.193$ & $<.08$ & $<.081$ & E.03 & $<.002$ \\
\hline 17 & .229 & E.098 & E.02 & $<.07$ & E.066 & $<.08$ & $<.081$ & $<.05$ & $<.002$ \\
\hline 18 & E.004 & $<.087$ & $<.06$ & $<.07$ & $<.193$ & $<.08$ & $<.081$ & $<.05$ & $<.002$ \\
\hline 20 & .005 & E.021 & M & $<.07$ & $<.193$ & $<.08$ & $<.081$ & $<.05$ & $<.002$ \\
\hline 22 & $<.001$ & $<.002$ & $<.06$ & $<.07$ & $<.193$ & $<.08$ & $<.081$ & $<.05$ & E.002 \\
\hline 24 & .115 & E.030 & E.01 & $<.07$ & $<.193$ & $<.08$ & $<.081$ & $<.05$ & $<.002$ \\
\hline 25 & .345 & E.106 & E.02 & $<.07$ & E.055 & $<.08$ & $<.081$ & $<.05$ & $<.002$ \\
\hline $26 \mathrm{D}$ & .009 & $<.002$ & $<.06$ & $<.07$ & $<.193$ & $<.08$ & $<.081$ & $<.05$ & $<.002$ \\
\hline $26 \mathrm{~S}$ & $<.001$ & $<.002$ & $<.06$ & $<.07$ & $<.193$ & $<.08$ & E.011 & $<.05$ & $<.002$ \\
\hline 27 & .019 & $<.002$ & $\mathrm{M}$ & $<.07$ & $<.193$ & $<.08$ & $<.081$ & $<.05$ & $<.002$ \\
\hline 29 & $<.001$ & $<.002$ & $<.06$ & $<.07$ & $<.193$ & $<.08$ & E.029 & $<.05$ & $<.002$ \\
\hline 30 & .012 & E.006 & $\mathrm{M}$ & $<.07$ & $<.193$ & $<.08$ & $<.081$ & $<.05$ & $<.002$ \\
\hline 31 & 1.03 & E.093 & E.04 & E.02 & E.185 & $<.08$ & $<.081$ & $<.05$ & $<.002$ \\
\hline 32 & $<.001$ & $<.002$ & $<.06$ & $<.07$ & $<.193$ & $<.08$ & $<.081$ & $<.05$ & $<.002$ \\
\hline 33 & .031 & E.022 & E.01 & $<.07$ & $<.193$ & $<.08$ & $<.081$ & $<.05$ & $<.002$ \\
\hline 34 & .018 & E.012 & $\mathrm{M}$ & $<.07$ & $<.193$ & $<.08$ & $<.081$ & $<.05$ & $<.002$ \\
\hline 37 & $<.001$ & $<.002$ & $<.06$ & $<.07$ & $<.193$ & $<.08$ & $<.081$ & $<.05$ & $<.002$ \\
\hline 39 & .029 & E.016 & $<.06$ & $<.07$ & $<.193$ & $<.08$ & $<.081$ & $<.05$ & $<.002$ \\
\hline 41 & $<.074$ & $<.087$ & $<.06$ & $<.07$ & $<.193$ & $<.08$ & $<.081$ & $<.05$ & $<.002$ \\
\hline
\end{tabular}

Geological Survey Office of Water Quality in 2001. Although the analytical method did not change following approval, data analyzed before method approval are considered provisional.

${ }^{2}$ Presence of compound in sample(s) may be the result of contamination. Compound was not included in analysis of pesticide data. 
Table 11. Concentration of dissolved pesticides detected in water sampled from monitoring wells in Salt Lake Valley, Utah, 1999—Continued

\begin{tabular}{|c|c|c|c|c|c|c|c|c|}
\hline $\begin{array}{c}\text { Well } \\
\text { identifier }\end{array}$ & $\begin{array}{l}\text { Diuron' } \\
\text { (49300) }\end{array}$ & $\begin{array}{l}\text { Imazaquin } \\
(50356)\end{array}$ & $\begin{array}{c}\text { Malathion } \\
\text { (39532) }\end{array}$ & $\begin{array}{c}\text { P,P' DDE } \\
(34653)\end{array}$ & $\begin{array}{c}\text { Picloram }{ }^{1} \\
\text { (49291) }\end{array}$ & $\begin{array}{c}\text { Prometon } \\
\text { (04037) }\end{array}$ & $\begin{array}{c}\text { Simazine } \\
(04035)\end{array}$ & $\begin{array}{c}\text { Tebuthiuron } \\
\text { (82670) }\end{array}$ \\
\hline 1 & $<0.08$ & $<0.103$ & $<0.005$ & $<0.006$ & $<0.07$ & 0.518 & 0.027 & $<0.010$ \\
\hline 2 & $<.08$ & $<.103$ & $<.010$ & $<.006$ & $<.07$ & .105 & .008 & .120 \\
\hline 3 & $<.08$ & $<.103$ & $<.005$ & $<.006$ & $<.07$ & $<.018$ & .019 & $<.010$ \\
\hline 4 & $<.08$ & $<.103$ & $<.010$ & $<.006$ & .47 & .043 & $<.005$ & $<.010$ \\
\hline 5 & $<.08$ & E.006 & $<.005$ & $<.006$ & $<.07$ & $<.018$ & .006 & $<.010$ \\
\hline 6 & $<.08$ & $<.103$ & $<.005$ & $<.006$ & $<.07$ & .021 & E.004 & .051 \\
\hline 7 & .32 & $<.103$ & $<.005$ & $<.006$ & $<.07$ & E.016 & .023 & $<.010$ \\
\hline 8 & $<.08$ & $<.103$ & $<.005$ & $<.006$ & $<.07$ & $<.018$ & $<.005$ & $<.010$ \\
\hline 9 & $<.08$ & $<.103$ & $<.005$ & $<.006$ & $<.07$ & .026 & .006 & $<.010$ \\
\hline 10 & $<.08$ & $<.103$ & $<.005$ & $<.006$ & $<.07$ & $<.018$ & $<.005$ & $<.010$ \\
\hline 11 & $<.08$ & $<.103$ & $<.005$ & $<.006$ & $<.07$ & $<.018$ & .013 & $<.010$ \\
\hline 14 & $<.08$ & $<.103$ & $<.005$ & $<.006$ & $<.07$ & $<.018$ & $<.005$ & $<.010$ \\
\hline 17 & $<.08$ & $<.103$ & $<.005$ & $<.006$ & $<.07$ & .022 & .010 & $<.010$ \\
\hline 18 & $<.08$ & $<.103$ & $<.005$ & $<.006$ & $<.07$ & .216 & .013 & E.028 \\
\hline 20 & $<.08$ & $<.103$ & .006 & $<.006$ & $<.07$ & $<.018$ & $<.005$ & $<.010$ \\
\hline 22 & $<.08$ & E.006 & $<.005$ & $<.006$ & $<.07$ & $<.018$ & $<.005$ & $<.010$ \\
\hline 24 & $<.08$ & $<.103$ & $<.005$ & $<.006$ & $<.07$ & $<.018$ & .009 & $<.010$ \\
\hline 25 & $<.08$ & $<.103$ & $<.005$ & $<.006$ & $<.07$ & E.015 & .011 & $<.010$ \\
\hline $26 \mathrm{D}$ & $<.08$ & $<.103$ & $<.005$ & $<.006$ & $<.07$ & $<.018$ & $<.005$ & $<.010$ \\
\hline $26 \mathrm{~S}$ & $<.08$ & $<.103$ & $<.005$ & $<.006$ & $<.07$ & E.005 & $<.005$ & $<.010$ \\
\hline 27 & $<.08$ & $<.103$ & $<.005$ & $<.006$ & $<.07$ & .125 & $<.005$ & $<.010$ \\
\hline 29 & $<.08$ & $<.103$ & $<.005$ & $<.006$ & $<.07$ & $<.018$ & $<.005$ & $<.010$ \\
\hline 30 & $<.08$ & $<.103$ & $<.005$ & $<.006$ & $<.07$ & .030 & $<.005$ & $<.010$ \\
\hline 31 & $<.08$ & $<.103$ & $<.005$ & $<.006$ & $<.07$ & $<.018$ & .018 & $<.010$ \\
\hline 32 & $<.08$ & $<.103$ & $<.005$ & $<.006$ & $<.07$ & $<.018$ & $<.005$ & $<.010$ \\
\hline 33 & $<.08$ & $<.103$ & $<.005$ & $<.006$ & $<.07$ & $<.018$ & $<.005$ & $<.010$ \\
\hline 34 & $<.08$ & $<.103$ & $<.005$ & $<.006$ & $<.07$ & .119 & $<.005$ & $<.010$ \\
\hline 37 & $<.08$ & $<.103$ & $<.005$ & $<.006$ & $<.07$ & $<.018$ & $<.005$ & $<.010$ \\
\hline 39 & $<.08$ & $<.103$ & $<.005$ & E.002 & $<.07$ & E.004 & $<.005$ & $<.010$ \\
\hline 41 & $<.08$ & $<.103$ & $<.005$ & $<.006$ & $<.07$ & .262 & $<.005$ & E.012 \\
\hline
\end{tabular}


Table 12. Volatile organic compounds analyzed for in water sampled from monitoring wells in Salt Lake Valley, Utah, 1999

[Parameter code is used in U.S. Geological Survey National Water Information System database; —, no number]

\begin{tabular}{|c|c|c|c|}
\hline Compound & Parameter code & $\begin{array}{l}\text { Chemical Abstracts Service } \\
\text { registry number }\end{array}$ & $\begin{array}{l}\text { Laboratory reporting level } \\
\qquad(\mu \mathrm{g} / \mathrm{L})\end{array}$ \\
\hline $1,1,1,2$-Tetrachloroethane & 77562 & $630-20-6$ & 0.03 \\
\hline 1,1,1-Trichloroethane & 34506 & $71-55-6$ & .03 \\
\hline 1,1,2,2-Tetrachloroethane & 34516 & $79-34-5$ & .09 \\
\hline 1,1,2-Trichloroethane & 34511 & $79-00-5$ & .06 \\
\hline 1,1,2-Trichlorotrifluoroethane & 77652 & $76-13-1$ & .06 \\
\hline 1,1-Dichloroethane & 34496 & $75-34-3$ & .07 \\
\hline 1,1-Dichloroethylene & 34501 & $75-35-4$ & .04 \\
\hline 1,1-Dichloropropene & 77168 & $563-58-6$ & .03 \\
\hline 1,2,3,4-Tetramethylbenzene & 49999 & $488-23-3$ & .2 \\
\hline 1,2,3,5-Tetramethylbenzene & 50000 & $527-53-7$ & .2 \\
\hline 1,2,3-Trichlorobenzene & 77613 & $87-61-6$ & .3 \\
\hline 1,2,3-Trichloropropane & 77443 & $96-18-4$ & .2 \\
\hline 1,2,3-Trimethylbenzene & 77221 & $526-73-8$ & .1 \\
\hline 1,2,4-Trichlorobenzene & 34551 & $120-82-1$ & .2 \\
\hline 1,2,4-Trimethylbenzene & 77222 & $95-63-6$ & .06 \\
\hline 1,2-Dibromo-3-chloropropane & 82625 & $96-12-8$ & .2 \\
\hline 1,2-Dibromoethane & 77651 & $106-93-4$ & .04 \\
\hline 1,2-Dichlorobenzene & 34536 & $95-50-1$ & .05 \\
\hline 1,2-Dichloroethane & 32103 & $107-06-2$ & .1 \\
\hline 1,2-Dichloropropane & 34541 & $78-87-5$ & .07 \\
\hline 1,3,5-Trimethylbenzene & 77226 & $108-67-8$ & .04 \\
\hline 1,3-Dichlorobenzene & 34566 & $541-73-1$ & .05 \\
\hline 1,3-Dichloropropane & 77173 & $142-28-9$ & .1 \\
\hline 1,4-Dichlorobenzene & 34571 & $106-46-7$ & .05 \\
\hline 2,2-Dichloropropane & 77170 & $594-20-7$ & .05 \\
\hline 2-Butanone & 81595 & $78-93-3$ & 2 \\
\hline 2-Chlorotoluene & 77275 & $95-49-8$ & .04 \\
\hline 2-Hexanone & 77103 & $591-78-6$ & .7 \\
\hline 3-Chloropropene & 78109 & $107-05-1$ & .2 \\
\hline 4-Chlorotoluene & 77277 & $106-43-4$ & .06 \\
\hline 4-Isopropyl-1-methylbenzene & 77356 & $99-87-6$ & .07 \\
\hline 4-Methyl-2-pentanone & 78133 & $108-10-1$ & .4 \\
\hline Acetone & 81552 & $67-64-1$ & 7 \\
\hline Acrylonitrile & 34215 & $107-13-1$ & 1 \\
\hline Benzene & 34030 & $71-43-2$ & .04 \\
\hline Bromobenzene & 81555 & $108-86-1$ & .04 \\
\hline Bromochloromethane & 77297 & $74-97-5$ & .04 \\
\hline Bromodichloromethane & 32101 & $75-27-4$ & .05 \\
\hline Bromoform & 32104 & $75-25-2$ & .06 \\
\hline Bromomethane & 34413 & $74-83-9$ & .3 \\
\hline Butylbenzene & 77342 & $104-51-8$ & .2 \\
\hline Carbon disulfide & 77041 & $75-15-0$ & .07 \\
\hline Chlorobenzene & 34301 & $108-90-7$ & .03 \\
\hline Chloroethane & 34311 & $75-00-3$ & .1 \\
\hline Chloroform & 32106 & $67-66-3$ & .05 \\
\hline Chloromethane & 34418 & $74-87-3$ & .5 \\
\hline Dibromochloromethane & 32105 & $124-48-1$ & .2 \\
\hline Dibromomethane & 30217 & $74-95-3$ & .05 \\
\hline
\end{tabular}


Table 12. Volatile organic compounds analyzed for in water sampled from monitoring wells in Salt Lake Valley, Utah, 1999_Continued

\begin{tabular}{|c|c|c|c|}
\hline Compound & Parameter code & $\begin{array}{l}\text { Chemical Abstracts Service } \\
\text { registry number }\end{array}$ & $\begin{array}{l}\text { Laboratory reporting level } \\
\qquad(\mu \mathrm{g} / \mathrm{L})\end{array}$ \\
\hline Dichlorodifluoromethane & 34668 & $75-71-8$ & .3 \\
\hline Dichloromethane & 34423 & $75-09-2$ & .4 \\
\hline Diethyl ether & 81576 & $60-29-7$ & .2 \\
\hline Diisopropyl ether & 81577 & $108-20-3$ & .1 \\
\hline Ethyl methacrylate & 73570 & $97-63-2$ & .2 \\
\hline Ethyl tert-butyl ether & 50004 & $637-92-3$ & .05 \\
\hline Ethylbenzene & 34371 & $100-41-4$ & .03 \\
\hline Hexachlorobutadiene & 39702 & $87-68-3$ & .1 \\
\hline Hexachloroethane & 34396 & $67-72-1$ & .2 \\
\hline Isopropylbenzene & 77223 & $98-82-8$ & .03 \\
\hline Methyl acrylate & 49991 & $96-33-3$ & 1 \\
\hline Methyl acrylonitrile & 81593 & $126-98-7$ & .6 \\
\hline Methyl iodide & 77424 & $74-88-4$ & .1 \\
\hline Methyl methacrylate & 81597 & $80-62-6$ & .3 \\
\hline Naphthalene & 34696 & $91-20-3$ & .2 \\
\hline Styrene & 77128 & $100-42-5$ & .04 \\
\hline Tetrachloroethylene & 34475 & $127-18-4$ & .1 \\
\hline Tetrachloromethane & 32102 & $56-23-5$ & .06 \\
\hline Tetrahydrofuran & 81607 & $109-99-9$ & 2 \\
\hline Toluene & 34010 & $108-88-3$ & .05 \\
\hline Trichloroethylene & 39180 & 79-01-6 & .04 \\
\hline Trichlorofluoromethane & 34488 & $75-69-4$ & .09 \\
\hline Vinyl bromide & 50002 & $593-60-2$ & .1 \\
\hline Vinyl chloride & 39175 & 75-01-4 & .1 \\
\hline cis-1,2-Dichloroethylene & 77093 & $156-59-2$ & .04 \\
\hline cis-1,3-Dichloropropene & 34704 & $10061-01-5$ & .09 \\
\hline $\mathrm{m}$ - and p-Xylene & 85795 & - & .06 \\
\hline n-Propylbenzene & 77224 & $103-65-1$ & .04 \\
\hline o-Ethyl toluene & 77220 & $611-14-3$ & .06 \\
\hline o-Xylene & 77135 & $95-47-6$ & .04 \\
\hline sec-Butylbenzene & 77350 & $135-98-8$ & .03 \\
\hline tert-Butyl methyl ether & 78032 & $1634-04-4$ & .2 \\
\hline tert-Butylbenzene & 77353 & 98-06-6 & .06 \\
\hline tert-Pentyl methyl ether & 50005 & $994-05-8$ & .1 \\
\hline trans-1,2-Dichloroethylene & 34546 & $156-60-5$ & .03 \\
\hline trans-1,3-Dichloropropene & 34699 & $10061-02-6$ & .09 \\
\hline trans-1,4-Dichloro-2-butene & 73547 & $110-57-6$ & .7 \\
\hline
\end{tabular}


Table 13. Concentration of volatile organic compounds detected in water sampled from monitoring wells in Salt Lake Valley, Utah, 1999

[Well identifier corresponds to site shown in figure 3 and listed in table 6; number below the parameter name is the U.S. Geological Survey National Water Information System parameter code; concentration reported in micrograms per liter; <, less than; E, estimated value; M, presence of compound verified but not quantified]

\begin{tabular}{|c|c|c|c|c|c|c|c|c|c|c|c|c|}
\hline $\begin{array}{c}\text { Well } \\
\text { identifier }\end{array}$ & $\begin{array}{c}\text { Benzene }^{1} \\
\text { (34030) }\end{array}$ & $\begin{array}{c}\text { Bromo- } \\
\text { dichloro- } \\
\text { methane } \\
(32101)\end{array}$ & $\begin{array}{c}\text { Carbon } \\
\text { disulfide } \\
\text { (77041) }\end{array}$ & $\begin{array}{l}\text { Chloroform } \\
\text { (32106) }\end{array}$ & $\begin{array}{c}\text { Chloro- } \\
\text { methane } \\
\text { (34418) }\end{array}$ & $\begin{array}{c}\text { 1,1- } \\
\text { Dichloro- } \\
\text { ethane } \\
(34496)\end{array}$ & $\begin{array}{c}\text { 1,2- } \\
\text { Dichloro- } \\
\text { ethane } \\
(32103)\end{array}$ & $\begin{array}{c}1,1- \\
\text { Dichloro- } \\
\text { ethylene } \\
(34501)\end{array}$ & $\begin{array}{c}\text { Dichloro- } \\
\text { methane } \\
\text { (34423) }\end{array}$ & $\begin{array}{c}\text { Ethyl- } \\
\text { benzene } \\
\text { (34371) }\end{array}$ & $\begin{array}{l}\text { o-Ethyl- } \\
\text { toluene } \\
\text { (77220) }\end{array}$ & $\begin{array}{l}\text { Methyl } \\
\text { tert-butyl } \\
\text { ether } \\
\text { (MTBE) } \\
\text { (78032) }\end{array}$ \\
\hline 1 & $<0.04$ & 0.27 & $<0.07$ & 1.97 & $<0.5$ & $<0.07$ & $<0.1$ & $<0.04$ & E0.1 & $<0.03$ & $<0.06$ & $<0.2$ \\
\hline 2 & $<.04$ & E.05 & $<.07$ & .55 & $<.5$ & E.03 & $<.1$ & E.01 & $<.4$ & $<.03$ & $<.06$ & $<.2$ \\
\hline 3 & $<.04$ & E. 02 & $<.07$ & E.08 & $<.5$ & $<.07$ & $<.1$ & $<.04$ & $<.4$ & $<.03$ & $<.06$ & $<.2$ \\
\hline 4 & $<.04$ & $<.05$ & E.05 & .29 & $<.5$ & $<.07$ & $<.1$ & $<.04$ & E. 3 & $<.03$ & $<.06$ & $<.2$ \\
\hline 5 & $<.04$ & .16 & $<.07$ & .97 & $<.5$ & $<.07$ & .4 & $<.04$ & M & $<.03$ & $<.06$ & $<.2$ \\
\hline 6 & $<.04$ & $<.05$ & $<.07$ & $<.05$ & $<.5$ & $<.07$ & $<.1$ & $<.04$ & $<.4$ & $<.03$ & $<.06$ & $<.2$ \\
\hline 7 & $<.04$ & $<.05$ & E.10 & E.09 & $<.5$ & $<.07$ & $<.1$ & $<.04$ & E.1 & $<.03$ & $<.06$ & $<.2$ \\
\hline 8 & $<.04$ & .24 & $<.07$ & 1.16 & $<.5$ & $<.07$ & $<.1$ & $<.04$ & $<.4$ & $<.03$ & $<.06$ & $<.2$ \\
\hline 9 & $<.04$ & E.07 & $<.07$ & .88 & $<.5$ & $<.07$ & $<.1$ & $<.04$ & $<.4$ & $<.03$ & $<.06$ & $<.2$ \\
\hline 10 & $<.04$ & E.03 & $<.07$ & .18 & $<.5$ & $<.07$ & $<.1$ & $<.04$ & $<.4$ & $<.03$ & $<.06$ & $<.2$ \\
\hline 11 & $<.04$ & $<.05$ & $<.07$ & E.03 & $<.5$ & $<.07$ & $<.1$ & $<.04$ & $<.4$ & $<.03$ & $<.06$ & $<.2$ \\
\hline 14 & $<.04$ & E.04 & $<.07$ & .49 & $<.5$ & $<.07$ & $<.1$ & $<.04$ & E.1 & $<.03$ & $<.06$ & $<.2$ \\
\hline 17 & $<.04$ & $<.05$ & $<.07$ & .94 & $<.5$ & $<.07$ & $<.1$ & $<.04$ & M & $<.03$ & $<.06$ & $<.2$ \\
\hline 18 & $<.10$ & .19 & $<.37$ & 1.53 & $<.2$ & $<.07$ & $<.1$ & $<.04$ & $<.4$ & $<.03$ & $<.10$ & $<.2$ \\
\hline 20 & $<.04$ & .26 & $<.07$ & 2.41 & $<.5$ & $<.07$ & $<.1$ & $<.04$ & $<.4$ & $<.03$ & $<.06$ & $<.2$ \\
\hline 22 & $<.04$ & $<.05$ & $<.07$ & .10 & $<.5$ & $<.07$ & $<.1$ & $<.04$ & $<.4$ & $<.03$ & $<.06$ & $<.2$ \\
\hline 24 & $<.04$ & .12 & $<.07$ & .64 & $<.5$ & $<.07$ & $<.1$ & $<.04$ & $<.4$ & $<.03$ & $<.06$ & $<.2$ \\
\hline 25 & $<.04$ & .12 & $<.07$ & .65 & $<.5$ & $<.07$ & $<.1$ & $<.04$ & $<.4$ & $<.03$ & $<.06$ & $<.2$ \\
\hline $26 \mathrm{D}$ & $<.10$ & E.03 & $<.37$ & .22 & $<.2$ & $<.07$ & $<.1$ & $<.04$ & $<.4$ & $<.03$ & $<.10$ & $<.2$ \\
\hline $26 \mathrm{~S}$ & $<.10$ & $<.05$ & $<.37$ & E.10 & $<.2$ & $<.07$ & $<.1$ & $<.04$ & $<.4$ & $<.03$ & $<.10$ & $<.2$ \\
\hline 27 & $<.10$ & .51 & $<.37$ & 2.11 & $<.2$ & $<.07$ & $<.1$ & $<.04$ & $<.4$ & $<.03$ & $<.10$ & E.1 \\
\hline 29 & $<.17$ & $<.24$ & $<.35$ & $<.26$ & $<2.5$ & $<.33$ & $<.7$ & $<.20$ & $<1.9$ & $<.15$ & $<.30$ & $<.8$ \\
\hline 30 & $<.04$ & .23 & $<.07$ & 1.28 & $<.5$ & $<.07$ & $<.1$ & $<.04$ & $<.4$ & $<.03$ & $<.06$ & $<.2$ \\
\hline 31 & $<.04$ & E.04 & $<.07$ & .31 & $<.5$ & $<.07$ & $<.1$ & $<.04$ & $<.4$ & $<.03$ & $<.06$ & $<.2$ \\
\hline 32 & M & $<.05$ & $<.37$ & $<.05$ & $<.2$ & $<.07$ & $<.1$ & $<.04$ & $<.4$ & E.02 & E.01 & $<.2$ \\
\hline 33 & $<.04$ & $<.05$ & $<.07$ & .13 & $<.5$ & $<.07$ & $<.1$ & E.05 & $<.4$ & $<.03$ & $<.06$ & $<.2$ \\
\hline 34 & E.01 & $<.05$ & $<.37$ & E.03 & E.1 & $<.07$ & $<.1$ & $<.04$ & $<.4$ & E.01 & $<.10$ & $<.2$ \\
\hline 37 & $<.10$ & $<.05$ & E.01 & .19 & $<.2$ & $<.07$ & $<.1$ & $<.04$ & $<.4$ & $<.03$ & $<.10$ & $<.2$ \\
\hline 39 & $<.04$ & E.04 & $<.07$ & .24 & $<.5$ & $<.07$ & $<.1$ & $<.04$ & $<.4$ & $<.03$ & $<.06$ & $<.2$ \\
\hline 41 & $<.04$ & $<.05$ & $<.07$ & E.06 & $<.5$ & $<.07$ & $<.1$ & $<.04$ & $<.4$ & $<.03$ & $<.06$ & $<.2$ \\
\hline
\end{tabular}


Table 13. Concentration of volatile organic compounds detected in water sampled from monitoring wells in Salt Lake Valley, Utah, 1999_-Continued

\begin{tabular}{|c|c|c|c|c|c|c|c|c|c|c|c|c|}
\hline $\begin{array}{c}\text { Well } \\
\text { identifier }\end{array}$ & $\begin{array}{c}\text { Tetrachloro- } \\
\text { ethylene } \\
\text { (PCE) } \\
\text { (34475) }\end{array}$ & $\begin{array}{c}\text { Tetrachloro- } \\
\text { methane } \\
(32102)\end{array}$ & $\begin{array}{c}\text { Toluene }^{1} \\
(34010)\end{array}$ & $\begin{array}{c}1,1,1- \\
\text { Trichloro- } \\
\text { ethane } \\
\text { (TCA) } \\
\text { (34506) }\end{array}$ & $\begin{array}{c}\text { Trichloro- } \\
\text { ethylene } \\
\text { (TCE) } \\
(39180)\end{array}$ & $\begin{array}{c}\text { Trichloro- } \\
\text { fluoro- } \\
\text { methane } \\
\text { (CFC-11) } \\
\text { (34488) }\end{array}$ & $\begin{array}{c}1,1,2- \\
\text { Trichloro- } \\
\text { trifluoro- } \\
\text { ethane } \\
\text { (CFC-113) } \\
\text { (77652) }\end{array}$ & $\begin{array}{c}1,2,3- \\
\text { Trimethyl- } \\
\text { benzene }^{1} \\
(77221)\end{array}$ & $\begin{array}{c}\text { 1,2,4- } \\
\text { Trimethyl- } \\
\text { benzene }^{1} \\
\text { (77222) }\end{array}$ & $\begin{array}{c}1,3,5- \\
\text { Trimethyl- } \\
\text { benzene }{ }^{1} \\
\text { (77226) }\end{array}$ & $\begin{array}{c}\text { m- and p- } \\
\text { Xylene }^{1} \\
\text { (85795) }\end{array}$ & $\begin{array}{c}\text { o-Xylene }{ }^{1} \\
\text { (77135) }\end{array}$ \\
\hline 1 & 4.8 & $<0.06$ & $<0.05$ & E0.08 & E0.04 & $<0.09$ & $<0.06$ & $<0.1$ & $<0.06$ & $<0.04$ & $<0.06$ & $<0.04$ \\
\hline 2 & .1 & $<.06$ & $<.05$ & .22 & 1.54 & $<.09$ & $<.06$ & $<.1$ & $<.06$ & $<.04$ & $<.06$ & $<.04$ \\
\hline 3 & $<.1$ & $<.06$ & $<.05$ & .12 & $<.04$ & $<.09$ & $<.06$ & $<.1$ & $<.06$ & $<.04$ & $<.06$ & $<.04$ \\
\hline 4 & $\mathrm{M}$ & $<.06$ & $<.05$ & $<.03$ & $<.04$ & $<.09$ & $<.06$ & $<.1$ & $<.06$ & $<.04$ & $<.06$ & $<.04$ \\
\hline 5 & 7.8 & $<.06$ & $<.05$ & $<.03$ & E.06 & $<.09$ & $<.06$ & $<.1$ & $<.06$ & $<.04$ & $<.06$ & $<.04$ \\
\hline 6 & $<.1$ & $<.06$ & $<.05$ & $<.03$ & $<.04$ & $<.09$ & $<.06$ & $<.1$ & $<.06$ & $<.04$ & $<.06$ & $<.04$ \\
\hline 7 & $\mathrm{M}$ & $<.06$ & $<.05$ & $<.03$ & $<.04$ & $<.09$ & $<.06$ & $<.1$ & $<.06$ & $<.04$ & $<.06$ & $<.04$ \\
\hline 8 & 1.9 & $<.06$ & $<.05$ & E.01 & $<.04$ & $<.09$ & $<.06$ & $<.1$ & $<.06$ & $<.04$ & $<.06$ & $<.04$ \\
\hline 9 & 1.2 & $<.06$ & $<.05$ & $<.03$ & E.03 & $<.09$ & $<.06$ & $<.1$ & $<.06$ & $<.04$ & $<.06$ & $<.04$ \\
\hline 10 & $\mathrm{M}$ & $<.06$ & $<.05$ & E.05 & E.02 & $<.09$ & $<.06$ & $<.1$ & $<.06$ & $<.04$ & $<.06$ & $<.04$ \\
\hline 11 & $<.1$ & $<.06$ & $<.05$ & $<.03$ & $<.04$ & $<.09$ & $<.06$ & $<.1$ & $<.06$ & $<.04$ & E.02 & $<.04$ \\
\hline 14 & $<.1$ & $<.06$ & $<.05$ & E.02 & $<.04$ & $<.09$ & $<.06$ & $<.1$ & $<.06$ & $<.04$ & $<.06$ & $<.04$ \\
\hline 17 & $<.1$ & $<.06$ & $<.05$ & $<.03$ & $<.04$ & $<.09$ & $<.06$ & $<.1$ & $<.06$ & $<.04$ & $<.06$ & $<.04$ \\
\hline 18 & .5 & $<.09$ & $<.05$ & E.04 & $<.04$ & $<.09$ & $<.03$ & $<.1$ & $<.06$ & $<.04$ & $<.06$ & $<.06$ \\
\hline 20 & $<.1$ & $<.06$ & $<.05$ & E.02 & $<.04$ & $<.09$ & $<.06$ & $<.1$ & $<.06$ & $<.04$ & $<.06$ & $<.04$ \\
\hline 22 & $<.1$ & $<.06$ & $<.05$ & $<.03$ & $<.04$ & $<.09$ & $<.06$ & $<.1$ & $<.06$ & $<.04$ & $<.06$ & $<.04$ \\
\hline 24 & $<.1$ & $<.06$ & $<.05$ & E.04 & $<.04$ & $<.09$ & $<.06$ & $<.1$ & $<.06$ & $<.04$ & $<.06$ & $<.04$ \\
\hline 25 & $\mathrm{M}$ & $<.06$ & $<.05$ & E.01 & $<.04$ & $<.09$ & $<.06$ & $<.1$ & $<.06$ & $<.04$ & $<.06$ & $<.04$ \\
\hline $26 \mathrm{D}$ & $\mathrm{M}$ & $<.09$ & $<.05$ & $<.03$ & $<.04$ & $<.09$ & $<.03$ & $<.1$ & $<.06$ & $<.04$ & $<.06$ & $<.06$ \\
\hline $26 \mathrm{~S}$ & $<.1$ & $<.09$ & $<.05$ & $<.03$ & $<.04$ & $<.09$ & $<.03$ & $<.1$ & $<.06$ & $<.04$ & $<.06$ & $<.06$ \\
\hline 27 & .8 & $<.09$ & $<.05$ & E.02 & $<.04$ & $<.09$ & $<.03$ & $<.1$ & $<.06$ & $<.04$ & $<.06$ & $<.06$ \\
\hline 29 & $<.5$ & $<.30$ & $<.25$ & $<.16$ & $<.19$ & $<.45$ & $<.30$ & $<.6$ & $<.28$ & $<.22$ & $<.30$ & $<.19$ \\
\hline 30 & .6 & $<.06$ & $<.05$ & $<.03$ & $<.04$ & $<.09$ & $<.06$ & $<.1$ & $<.06$ & $<.04$ & $<.06$ & $<.04$ \\
\hline 31 & M & $<.06$ & $<.05$ & E.02 & $<.04$ & $<.09$ & $<.06$ & $<.1$ & $<.06$ & $<.04$ & $<.06$ & $<.04$ \\
\hline 32 & $<.1$ & $<.09$ & $<.05$ & $<.03$ & $<.04$ & $<.09$ & $<.03$ & $\mathrm{M}$ & E.03 & E.01 & E.08 & E.02 \\
\hline 33 & $<.1$ & $<.06$ & $<.05$ & .10 & $<.04$ & E.09 & E.08 & $<.1$ & $<.06$ & $<.04$ & $<.06$ & $<.04$ \\
\hline 34 & $\mathrm{M}$ & $<.09$ & E.01 & $<.03$ & $<.04$ & $<.09$ & $<.03$ & $<.1$ & E.01 & $<.04$ & E.03 & $<.06$ \\
\hline 37 & $<.1$ & $<.09$ & $<.05$ & E.01 & $<.04$ & E.04 & $<.03$ & $<.1$ & $<.06$ & $<.04$ & E.01 & $<.06$ \\
\hline 39 & $<.1$ & E.01 & $<.05$ & E.01 & $<.04$ & $<.09$ & $<.06$ & $<.1$ & $<.06$ & $<.04$ & $<.06$ & $<.04$ \\
\hline 41 & $\mathrm{M}$ & $<.06$ & E.01 & $<.03$ & $<.04$ & $<.09$ & $<.06$ & $<.1$ & $<.06$ & $<.04$ & $<.06$ & $<.04$ \\
\hline
\end{tabular}


Table 14. Quality-control data for dissolved major ions in blank water and water sampled from monitoring wells in Salt Lake Valley, Utah, 1999

[Well identifier corresponds to site shown in figure 3 and listed in table 6; numbers in bold indicate detection in the field-blank sample; mg/L, milligrams per liter; $\mu \mathrm{g} / \mathrm{L}$, microgram per liter; ${ }^{\circ} \mathrm{C}$, degrees Celsius; number below parameter name is the U.S. Geological Survey National Water Information System parameter code; - , no data; <, less than; E, estimated value; M, presence of constituent is verified but not quantified]

\begin{tabular}{|c|c|c|c|c|c|c|c|c|}
\hline $\begin{array}{c}\text { Well } \\
\text { identifier }\end{array}$ & $\begin{array}{l}\text { Sample } \\
\text { date }\end{array}$ & $\begin{array}{c}\text { Sample } \\
\text { time }\end{array}$ & $\begin{array}{c}\text { Sample } \\
\text { type }\end{array}$ & $\begin{array}{c}\text { Bicarbonate } \\
(\mathrm{mg} / \mathrm{L} \\
\left.\text { as } \mathrm{HCO}_{3}\right) \\
(00453)\end{array}$ & $\begin{array}{c}\text { Bromide } \\
\text { (mg/L as Br) } \\
(71870)\end{array}$ & $\begin{array}{l}\text { Calcium } \\
\text { (mg/L as Ca) } \\
\text { (00915) }\end{array}$ & $\begin{array}{c}\text { Chloride } \\
\text { (mg/L as Cl) } \\
\text { (00940) }\end{array}$ & $\begin{array}{c}\text { Fluoride } \\
\text { (mg/L as F) } \\
(00950)\end{array}$ \\
\hline $26 \mathrm{D}$ & 08/10/1999 & 1606 & Field blank & - & $<0.01$ & E0.01 & $<0.1$ & $<0.1$ \\
\hline $26 \mathrm{~S}$ & 09/15/1999 & 1106 & Field blank & - & $<.01$ & .02 & $<.3$ & $<.1$ \\
\hline 1 & 09/22/1999 & 1006 & Field blank & - & $<.01$ & $<.02$ & $<.3$ & $<.1$ \\
\hline 22 & 09/29/1999 & 1106 & Field blank & - & $<.01$ & $<.02$ & $<.3$ & $<.1$ \\
\hline 10 & 10/13/1999 & 1206 & Field blank & - & $<.01$ & $<.02$ & $<.3$ & $<.1$ \\
\hline 31 & $10 / 21 / 1999$ & 1106 & Field blank & - & $<.01$ & .02 & $<.3$ & $<.1$ \\
\hline 34 & $09 / 09 / 1999$ & 1100 & Ground water & 324 & .10 & 99.8 & 101 & .9 \\
\hline 34 & 09/09/1999 & 1101 & Replicate & 324 & $<.01$ & 100 & 100 & .9 \\
\hline 39 & $10 / 04 / 1999$ & 1100 & Ground water & 363 & .06 & 93.4 & 47.2 & .5 \\
\hline 39 & $10 / 04 / 1999$ & 1101 & Replicate & 357 & .06 & 93.4 & 47.0 & .4 \\
\hline 3 & $10 / 19 / 1999$ & 1100 & Ground water & 360 & .25 & 89.1 & 191 & .6 \\
\hline 3 & $10 / 19 / 1999$ & 1101 & Replicate & 360 & .24 & 86.8 & 185 & .7 \\
\hline $\begin{array}{c}\text { Well } \\
\text { identifier }\end{array}$ & $\begin{array}{l}\text { Sample } \\
\text { date }\end{array}$ & $\begin{array}{c}\text { Sample } \\
\text { time }\end{array}$ & $\begin{array}{c}\text { Sample } \\
\text { type }\end{array}$ & $\begin{array}{c}\text { Iron } \\
(\mu \mathrm{g} / \mathrm{L} \text { as } \mathrm{Fe}) \\
(01046)\end{array}$ & $\begin{array}{l}\text { Magnesium } \\
\text { (mg/L as } \mathrm{Mg}) \\
(00925)\end{array}$ & $\begin{array}{c}\text { Manganese } \\
(\mu \mathrm{g} / \mathrm{L} \text { as } \mathrm{Mn}) \\
(01056)\end{array}$ & $\begin{array}{c}\text { Potassium } \\
\text { (mg/L as K) } \\
(00935)\end{array}$ & $\begin{array}{c}\text { Silica } \\
\left(\mathrm{mg} / \mathrm{L} \text { as } \mathrm{SiO}_{2}\right) \\
(00955)\end{array}$ \\
\hline $26 \mathrm{D}$ & 08/10/1999 & 1606 & Field blank & $<10$ & E.002 & $<3.0$ & $<.10$ & $<.1$ \\
\hline $26 \mathrm{~S}$ & 09/15/1999 & 1106 & Field blank & $<10$ & $<.014$ & $<2.2$ & $<.24$ & $<.1$ \\
\hline 1 & 09/22/1999 & 1006 & Field blank & $<10$ & $<.014$ & $<2.2$ & $<.24$ & $<.1$ \\
\hline 22 & 09/29/1999 & 1106 & Field blank & $<10$ & $<.014$ & $<2.2$ & $<.24$ & $<.1$ \\
\hline 10 & $10 / 13 / 1999$ & 1206 & Field blank & $<10$ & $<.014$ & $<2.2$ & $<.24$ & $<.1$ \\
\hline 31 & 10/21/1999 & 1106 & Field blank & $<10$ & E.008 & $<2.2$ & $<.24$ & $<.1$ \\
\hline 34 & 09/09/1999 & 1100 & Ground water & $<10$ & 30.0 & $<2.2$ & 7.21 & 30.3 \\
\hline 34 & 09/09/1999 & 1101 & Replicate & $<10$ & 30.4 & E1.4 & 7.68 & 30.6 \\
\hline 39 & $10 / 04 / 1999$ & 1100 & Ground water & $<10$ & 25.8 & 18.7 & 5.76 & 20.8 \\
\hline 39 & $10 / 04 / 1999$ & 1101 & Replicate & $<10$ & 25.7 & 18.7 & 5.35 & 20.8 \\
\hline 3 & $10 / 19 / 1999$ & 1100 & Ground water & $<10$ & 53.7 & 2.2 & 14.4 & 38.4 \\
\hline 3 & $10 / 19 / 1999$ & 1101 & Replicate & $<10$ & 52.7 & 2.9 & 14.1 & 37.6 \\
\hline $\begin{array}{c}\text { Well } \\
\text { identifier }\end{array}$ & $\begin{array}{l}\text { Sample } \\
\text { date }\end{array}$ & $\begin{array}{c}\text { Sample } \\
\text { time }\end{array}$ & $\begin{array}{c}\text { Sample } \\
\text { type }\end{array}$ & $\begin{array}{c}\text { Sodium } \\
\text { (mg/L as Na) } \\
(00930)\end{array}$ & $\begin{array}{c}\text { Sulfate } \\
\left(\mathrm{mg} / \mathrm{L} \text { as } \mathrm{SO}_{4}\right) \\
(00945)\end{array}$ & $\begin{array}{c}\text { Solids, residue } \\
\text { at } 180^{\circ} \mathrm{C} \\
(\mathrm{mg} / \mathrm{L}) \\
(70300)\end{array}$ & $\begin{array}{c}\text { Solids, sum of } \\
\text { constituents } \\
\text { (mg/L) } \\
(70301)\end{array}$ & \\
\hline $26 \mathrm{D}$ & $08 / 10 / 1999$ & 1606 & Field blank & $\mathbf{M}$ & $<.1$ & $<10$ & - & \\
\hline $26 S$ & 09/15/1999 & 1106 & Field blank & $<.1$ & $<.3$ & $<10$ & - & \\
\hline 1 & 09/22/1999 & 1006 & Field blank & $<.1$ & $<.3$ & $<10$ & - & \\
\hline 22 & 09/29/1999 & 1106 & Field blank & $<.1$ & $<.3$ & $<10$ & - & \\
\hline 10 & $10 / 13 / 1999$ & 1206 & Field blank & $<.1$ & $<.3$ & $<10$ & - & \\
\hline 31 & $10 / 21 / 1999$ & 1106 & Field blank & E.1 & $<.3$ & $<10$ & - & \\
\hline 34 & $09 / 09 / 1999$ & 1100 & Ground water & 65.8 & 85.4 & 626 & 614 & \\
\hline 34 & 09/09/1999 & 1101 & Replicate & 63.6 & 84.6 & 552 & 578 & \\
\hline 39 & 10/04/1999 & 1100 & Ground water & 53.7 & 64.4 & 521 & 534 & \\
\hline 39 & $10 / 04 / 1999$ & 1101 & Replicate & 53.0 & 64.3 & 531 & 528 & \\
\hline 3 & 10/19/1999 & 1100 & Ground water & 154 & 218 & 982 & 974 & \\
\hline 3 & $10 / 19 / 1999$ & 1101 & Replicate & 152 & 218 & 960 & 962 & \\
\hline
\end{tabular}


Table 15. Quality-control data for dissolved trace elements in blank water and water sampled from monitoring wells in Salt Lake Valley, Utah, 1999

[Well identifier corresponds to site shown in figure 3 and listed in table 6; numbers in bold indicate detection in the field-blank sample; water samples for Radon-222 analysis were not filtered; $\mu \mathrm{g} / \mathrm{L}$, micrograms per liter; number below the parameter name is the U.S. Geological Survey National Water Information System parameter code; <, less than; M, presence of constituent is verified but not quantified; E, estimated value; pCi/L, picocuries per liter; -, no data]

\begin{tabular}{|c|c|c|c|c|c|c|c|c|c|}
\hline $\begin{array}{c}\text { Well } \\
\text { identifier }\end{array}$ & $\begin{array}{c}\text { Sample } \\
\text { date }\end{array}$ & $\begin{array}{l}\text { Sample } \\
\text { time }\end{array}$ & Sample type & $\begin{array}{c}\text { Aluminum } \\
\text { ( } \mu \mathrm{g} / \mathrm{L} \text { as } \mathrm{AI}) \\
(01106)\end{array}$ & $\begin{array}{c}\text { Antimony } \\
\text { ( } \mu \mathrm{g} / \mathrm{L} \text { as } S \mathrm{~b}) \\
(01095)\end{array}$ & $\begin{array}{c}\text { Arsenic } \\
\text { ( } \mu \mathrm{g} / \mathrm{L} \text { as As) } \\
(01000)\end{array}$ & $\begin{array}{c}\text { Barium } \\
(\mu \mathrm{g} / \mathrm{L} \text { as } \mathrm{Ba}) \\
(01005)\end{array}$ & $\begin{array}{c}\text { Beryllium } \\
(\mu \mathrm{g} / \mathrm{L} \text { as } \mathrm{Be}) \\
(01010)\end{array}$ & $\begin{array}{l}\text { Cadmium } \\
\text { ( } \mu \mathrm{g} / \mathrm{L} \text { as } \mathrm{Cd}) \\
(01025)\end{array}$ \\
\hline $26 \mathrm{D}$ & $08 / 10 / 1999$ & 1611 & Field blank & $<0.3$ & $<0.20$ & $<1.0$ & $<0.2$ & $<0.20$ & $<0.30$ \\
\hline $26 \mathrm{~S}$ & 09/15/1999 & 1111 & Field blank & $\mathbf{M}$ & $<.20$ & $<1.0$ & .2 & $<.20$ & $<.30$ \\
\hline 1 & 09/22/1999 & 1011 & Field blank & $<.3$ & $<.20$ & $<1.0$ & $<.2$ & $<.20$ & $<.30$ \\
\hline 22 & 09/29/1999 & 1111 & Field blank & $<.3$ & $<.20$ & $<2.0$ & $<.2$ & $<.20$ & $<.30$ \\
\hline 10 & $10 / 13 / 1999$ & 1211 & Field blank & $<.3$ & $<.20$ & $<2.0$ & $<.2$ & $<.20$ & $<.30$ \\
\hline 31 & $10 / 21 / 1999$ & 1111 & Field blank & $<.3$ & $<.20$ & $<2.0$ & $<.2$ & $<.20$ & $<.30$ \\
\hline 34 & $09 / 09 / 1999$ & 1109 & Ground water & 2 & $<1.00$ & $<1.0$ & 112 & $<1.00$ & $<1.00$ \\
\hline 34 & 09/09/1999 & 1110 & Replicate & 2 & $<1.00$ & $<1.0$ & 113 & $<1.00$ & $<1.00$ \\
\hline 39 & $10 / 04 / 1999$ & 1109 & Ground water & 2 & $<1.00$ & 3.3 & 130 & $<1.00$ & $<1.00$ \\
\hline 39 & $10 / 04 / 1999$ & 1110 & Replicate & 1 & $<1.00$ & 3.1 & 131 & $<1.00$ & $<1.00$ \\
\hline 3 & $10 / 09 / 1999$ & 1109 & Ground water & 3 & $<1.00$ & 12.2 & 28.3 & $<1.00$ & $<1.00$ \\
\hline 3 & $10 / 09 / 1999$ & 1110 & Replicate & 4 & $<1.00$ & 12.6 & 27.9 & $<1.00$ & $<1.00$ \\
\hline $\begin{array}{c}\text { Well } \\
\text { identifer }\end{array}$ & $\begin{array}{l}\text { Sample } \\
\text { date }\end{array}$ & $\begin{array}{l}\text { Sample } \\
\text { time }\end{array}$ & Sample type & $\begin{array}{c}\text { Chromium } \\
\text { ( } \mu \mathrm{g} / \mathrm{L} \text { as } \mathrm{Cr}) \\
(01030)\end{array}$ & $\begin{array}{c}\text { Cobalt } \\
\text { ( } \mu \mathrm{g} / \mathrm{L} \text { as Co) } \\
(01035)\end{array}$ & $\begin{array}{c}\text { Copper } \\
\text { ( } \mu \mathrm{g} / \mathrm{L} \text { as } \mathrm{Cu}) \\
(01040)\end{array}$ & $\begin{array}{c}\text { Lead } \\
(\mu \mathrm{g} / \mathrm{L} \text { as } \mathrm{Pb}) \\
(01049)\end{array}$ & $\begin{array}{c}\text { Molybdenum } \\
\text { ( } \mu \mathrm{g} / \mathrm{L} \text { as } \mathrm{Mo}) \\
(01060)\end{array}$ & $\begin{array}{c}\text { Nickel } \\
\text { ( } \mu \mathrm{g} / \mathrm{L} \text { as } \mathrm{Ni}) \\
(01065)\end{array}$ \\
\hline $26 \mathrm{D}$ & $08 / 10 / 1999$ & 1611 & Field blank & .3 & $<.20$ & .7 & $<.30$ & $<.2$ & 1.04 \\
\hline $26 \mathrm{~S}$ & 09/15/1999 & 1111 & Field blank & .3 & $<.20$ & .3 & $<.30$ & $<.2$ & .51 \\
\hline 1 & $09 / 22 / 1999$ & 1011 & Field blank & .6 & $<.20$ & $<.2$ & $<.30$ & $<.2$ & $<.50$ \\
\hline 22 & 09/29/1999 & 1111 & Field blank & .3 & $<.20$ & .2 & $<.30$ & $<.2$ & $<.50$ \\
\hline 10 & $10 / 13 / 1999$ & 1211 & Field blank & $<.2$ & $<.20$ & $<.2$ & $<.30$ & $<.2$ & $<.50$ \\
\hline 31 & $10 / 21 / 1999$ & 1111 & Field blank & $<.2$ & $<.20$ & $<.2$ & $<.30$ & $<.2$ & $<.50$ \\
\hline 34 & $09 / 09 / 1999$ & 1109 & Ground water & $<1.0$ & $<1.00$ & 2.1 & $<1.00$ & 7.5 & 3.39 \\
\hline 34 & 09/09/1999 & 1110 & Replicate & $<1.0$ & $<1.00$ & 1.9 & $<1.00$ & 7.7 & 3.08 \\
\hline 39 & $10 / 04 / 1999$ & 1109 & Ground water & 1.5 & $<1.00$ & 2.3 & $<1.00$ & 3.4 & 3.24 \\
\hline 39 & $10 / 04 / 1999$ & 1110 & Replicate & 1.9 & $<1.00$ & 2.3 & $<1.00$ & 3.6 & 3.27 \\
\hline 3 & $10 / 09 / 1999$ & 1109 & Ground water & E.7 & $<1.00$ & 1.3 & $<1.00$ & 5.0 & 1.83 \\
\hline 3 & $10 / 09 / 1999$ & 1110 & Replicate & .9 & $<1.00$ & 1.7 & $<1.00$ & 5.0 & 2.09 \\
\hline $\begin{array}{c}\text { Well } \\
\text { identifier }\end{array}$ & $\begin{array}{c}\text { Sample } \\
\text { date }\end{array}$ & $\begin{array}{l}\text { Sample } \\
\text { time }\end{array}$ & Sample type & $\begin{array}{c}\text { Total radon-222 } \\
\text { (pCi/L) } \\
(82303)\end{array}$ & $\begin{array}{c}\text { Radon-222 }^{2-\text { sigma }^{1}} \\
\text { (pCi/L) } \\
(76002)\end{array}$ & $\begin{array}{l}\text { Selenium } \\
\text { ( } \mu \mathrm{g} / \mathrm{L} \text { as } \mathrm{Se}) \\
(01145)\end{array}$ & $\begin{array}{c}\text { Silver } \\
\text { ( } \mu \mathrm{g} / \mathrm{L} \text { as } \mathrm{Ag}) \\
(01075)\end{array}$ & $\begin{array}{c}\text { Uranium } \\
(\mu \mathrm{g} / \mathrm{L} \text { as } U) \\
(22703)\end{array}$ & $\begin{array}{c}\text { Zinc } \\
(\mu \mathrm{g} / \mathrm{L} \text { as } \mathrm{Zn}) \\
(01090)\end{array}$ \\
\hline $26 \mathrm{D}$ & $08 / 10 / 1999$ & 1611 & Field blank & - & - & $<1.0$ & $<.2$ & $<.20$ & 3 \\
\hline $26 \mathrm{~S}$ & 09/15/1999 & 1111 & Field blank & - & - & $<1.0$ & $<.2$ & $<.20$ & 6 \\
\hline 1 & 09/22/1999 & 1011 & Field blank & - & - & $<1.0$ & $<.2$ & $<.20$ & 2 \\
\hline 22 & 09/29/1999 & 1111 & Field blank & - & - & $<2.4$ & $<.2$ & $<.20$ & 1 \\
\hline 10 & $10 / 13 / 1999$ & 1211 & Field blank & - & - & $<2.4$ & $<.2$ & $<.20$ & $<.5$ \\
\hline 31 & $10 / 21 / 1999$ & 1111 & Field blank & - & - & $<2.4$ & $<.2$ & $<.20$ & $\mathbf{M}$ \\
\hline 34 & $09 / 09 / 1999$ & 1109 & Ground water & 491 & 31 & $<1.0$ & $<1.0$ & 36.2 & 5 \\
\hline 34 & 09/09/1999 & 1110 & Replicate & 499 & 31 & $<1.0$ & $<1.0$ & 36.7 & 4 \\
\hline 39 & $10 / 04 / 1999$ & 1109 & Ground water & 462 & 22 & $<2.4$ & $<1.0$ & 21.2 & 2 \\
\hline 39 & $10 / 04 / 1999$ & 1110 & Replicate & 536 & 23 & $<2.4$ & $<1.0$ & 21.5 & 2 \\
\hline 3 & $10 / 09 / 1999$ & 1109 & Ground water & 243 & 18 & 2.6 & $<1.0$ & 5.29 & 2 \\
\hline 3 & $10 / 09 / 1999$ & 1110 & Replicate & 222 & 18 & 2.6 & $<1.0$ & 5.37 & 4 \\
\hline
\end{tabular}


Table 16. Quality-control data for dissolved nutrient constituents and organic carbon in blank water and water sampled from monitoring wells in Salt Lake Valley, Utah, 1999

[Well identifier corresponds to site shown in figure 3 and listed in table 6; numbers in bold indicate detection in the field-blank sample; mg/L, milligrams per liter; number below the parameter name is the U.S. Geological Survey National Water Information System parameter code; <, less than; SS blank, sourcesolution blank; - , no data; E, estimated value]

\begin{tabular}{|c|c|c|c|c|c|c|c|c|c|c|}
\hline $\begin{array}{c}\text { Well } \\
\text { identifier }\end{array}$ & Sample date & $\begin{array}{c}\text { Sample } \\
\text { time }\end{array}$ & Sample type & $\begin{array}{c}\text { Ammonia } \\
\text { (mg/L as N) } \\
(00608)\end{array}$ & $\begin{array}{c}\text { Ammonia } \\
\text { plus organic } \\
\text { nitrogen } \\
\text { (mg/L as N) } \\
(00623)\end{array}$ & $\begin{array}{c}\text { Organic } \\
\text { carbon } \\
\text { (mg/L as C) } \\
(00681)\end{array}$ & $\begin{array}{c}\text { Nitrite } \\
\text { (mg/L as N) } \\
(00613)\end{array}$ & $\begin{array}{l}\text { Nitrite plus } \\
\text { nitrate } \\
\text { (mg/L as N) } \\
\text { (00631) }\end{array}$ & $\begin{array}{c}\text { Phosphorus } \\
\text { (mg/L as P) } \\
\text { (00666) }\end{array}$ & $\begin{array}{l}\text { Orthophos- } \\
\text { phorus } \\
\text { (mg/L as P) } \\
\text { (00671) }\end{array}$ \\
\hline $26 \mathrm{D}$ & $08 / 10 / 1999$ & 1605 & Field blank & $<0.020$ & $<0.10$ & 1.8 & $<0.010$ & $<0.050$ & $<0.004$ & $<0.010$ \\
\hline $26 \mathrm{D}$ & 08/10/1999 & 1607 & SS blank & - & - & $<.10$ & - & - & - & - \\
\hline $26 \mathrm{~S}$ & 09/15/1999 & 1105 & Field blank & $<.020$ & $<.10$ & 1.5 & $<.010$ & $<.050$ & $<.004$ & $<.010$ \\
\hline $26 \mathrm{~S}$ & 09/15/1999 & 1107 & SS blank & - & - & $<.10$ & - & - & - & - \\
\hline 1 & 09/22/1999 & 1005 & Field blank & $<.020$ & E.06 & .40 & $<.010$ & .117 & $<.004$ & $<.010$ \\
\hline 1 & 09/22/1999 & 1007 & SS blank & - & - & $<.10$ & - & - & - & - \\
\hline 22 & 09/29/1999 & 1105 & Field blank & $<.020$ & $<.10$ & 1.5 & $<.010$ & $<.050$ & $<.006$ & $<.010$ \\
\hline 22 & 09/29/1999 & 1107 & SS blank & - & - & $<.33$ & - & - & - & - \\
\hline 10 & $10 / 13 / 1999$ & 1205 & Field blank & .020 & $<.10$ & E.31 & $<.010$ & $<.050$ & $<.006$ & $<.010$ \\
\hline 10 & $10 / 13 / 1999$ & 1207 & SS blank & - & - & $<.33$ & - & - & - & - \\
\hline 31 & 10/21/1999 & 1105 & Field blank & $<.020$ & E.06 & .42 & $<.010$ & $<.050$ & $<.006$ & $<.010$ \\
\hline 31 & $10 / 21 / 1999$ & 1107 & SS blank & - & - & $<.33$ & - & - & - & - \\
\hline 39 & $10 / 04 / 1999$ & 1100 & Ground water & $<.020$ & .22 & 2.0 & .012 & 9.96 & .029 & .027 \\
\hline 39 & 10/04/1999 & 1101 & Replicate & $<.020$ & .19 & 2.0 & .012 & 9.61 & .030 & .020 \\
\hline 3 & 10/19/1999 & 1100 & Ground water & $<.020$ & .14 & E1.1 & $<.010$ & 8.55 & .028 & .028 \\
\hline 3 & $10 / 19 / 1999$ & 1101 & Replicate & $<.020$ & .12 & E.99 & $<.010$ & 8.49 & .029 & .029 \\
\hline
\end{tabular}


Table 17. Quality-control data for selected dissolved pesticides in blank water, 1999

[Well identifier corresponds to site shown in figure 3 and listed in table 6; numbers in bold indicate detection in the field-blank sample; number below the parameter name is the U.S. Geological Survey National Water Information System parameter code; concentration reported in micrograms per liter; <, less than; M, presence of compound verified but not quantified; E, estimated value]

\begin{tabular}{|c|c|c|c|c|c|c|c|c|c|}
\hline $\begin{array}{c}\text { Well } \\
\text { identifier }\end{array}$ & Sample date & Sample time & Sample type & $\begin{array}{c}\text { Atrazine }^{1} \\
(39632)\end{array}$ & $\begin{array}{c}\text { Deethylatrazine }^{1} \\
(04040)\end{array}$ & $\begin{array}{c}\text { Deethyl- } \\
\text { deisopropyl- } \\
\text { atrazine1, } 2,3 \\
(04039)\end{array}$ & $\begin{array}{c}\text { Deisopropyl- } \\
\text { atrazine }^{1,3} \\
(04038)\end{array}$ & $\begin{array}{c}\text { 2-Hydroxy- } \\
\text { atrazine }{ }^{1,3} \\
(50355)\end{array}$ & $\begin{array}{l}\text { Bromacil }^{1,3} \\
(04029)\end{array}$ \\
\hline $26 \mathrm{D}$ & $08 / 10 / 1999$ & 1605 & Field blank & $<0.001$ & $<0.002$ & $<0.06$ & $<0.07$ & $<0.193$ & $<0.08$ \\
\hline $26 \mathrm{~S}$ & 09/15/1999 & 1105 & Field blank & $<.001$ & $<.002$ & $<.06$ & $<.07$ & $<.193$ & $<.08$ \\
\hline 1 & $09 / 22 / 1999$ & 1005 & Field blank & $<.001$ & $<.002$ & $\mathbf{M}$ & $<.07$ & $<.193$ & $<.08$ \\
\hline 22 & 09/29/1999 & 1105 & Field blank & $<.001$ & $<.002$ & $<.06$ & $<.07$ & $<.193$ & $<.08$ \\
\hline 10 & $10 / 13 / 1999$ & 1205 & Field blank & $<.001$ & $<.002$ & $<.06$ & $<.07$ & $<.193$ & $<.08$ \\
\hline 31 & $10 / 21 / 1999$ & 1105 & Field blank & $<.001$ & $<.002$ & $<.06$ & $<.07$ & $<.193$ & $<.08$ \\
\hline $\begin{array}{c}\text { Well } \\
\text { identifier }\end{array}$ & Sample date & Sample time & Sample type & $\begin{array}{c}\text { Caffeine }^{1,3} \\
(50305)\end{array}$ & $\begin{array}{c}\text { Cycloate }^{1,2,3} \\
(04031)\end{array}$ & $\begin{array}{l}\text { Diazinon }^{1} \\
(39572)\end{array}$ & $\begin{array}{c}\text { Diuron } \\
(49300)\end{array}$ & $\begin{array}{c}\text { Fenuron }^{2,3} \\
(49297)\end{array}$ & $\begin{array}{c}\text { Imazaquin }^{1,2,3} \\
(50356)\end{array}$ \\
\hline $26 \mathrm{D}$ & $08 / 10 / 1999$ & 1605 & Field blank & $<.081$ & $<.05$ & $<.002$ & $<.08$ & $<.07$ & $<.103$ \\
\hline $26 \mathrm{~S}$ & 09/15/1999 & 1105 & Field blank & $<.081$ & $<.05$ & $<.002$ & $<.08$ & $<.07$ & $<.103$ \\
\hline 1 & 09/22/1999 & 1005 & Field blank & $<.081$ & $<.05$ & $<.002$ & $<.08$ & $\mathbf{M}$ & E.005 \\
\hline 22 & 09/29/1999 & 1105 & Field blank & $<.081$ & E.03 & $<.002$ & $<.08$ & $<.07$ & E.004 \\
\hline 10 & 10/13/1999 & 1205 & Field blank & $<.081$ & $<.05$ & $<.002$ & $<.08$ & $<.07$ & $<.103$ \\
\hline 31 & $10 / 21 / 1999$ & 1105 & Field blank & $<.081$ & $<.05$ & $<.002$ & $<.08$ & $<.07$ & $<.103$ \\
\hline $\begin{array}{c}\text { Well } \\
\text { identifier }\end{array}$ & Sample date & Sample time & Sample type & $\begin{array}{c}\text { Malathion } \\
\text { (30532) }\end{array}$ & $\begin{array}{c}\text { P,P' DDE }^{1} \\
(34653)\end{array}$ & $\begin{array}{l}\text { Picloram } 1,3 \\
(49291)\end{array}$ & $\begin{array}{l}\text { Prometon } \\
\text { (04037) }\end{array}$ & $\begin{array}{c}\text { Simazine }^{1} \\
(04035)\end{array}$ & $\begin{array}{c}\text { Tebuthiuron }^{1} \\
\text { (82670) }\end{array}$ \\
\hline $26 \mathrm{D}$ & $08 / 10 / 1999$ & 1605 & Field blank & $<.005$ & $<.006$ & $<.07$ & $<.018$ & $<.005$ & $<.010$ \\
\hline $26 \mathrm{~S}$ & 09/15/1999 & 1105 & Field blank & $<.005$ & $<.006$ & $<.07$ & $<.018$ & $<.005$ & $<.010$ \\
\hline 1 & 09/22/1999 & 1005 & Field blank & $<.005$ & $<.006$ & $<.07$ & $<.018$ & $<.005$ & $<.010$ \\
\hline 22 & 09/29/1999 & 1105 & Field blank & $<.005$ & $<.006$ & $<.07$ & $<.018$ & $<.005$ & $<.010$ \\
\hline 10 & $10 / 13 / 1999$ & 1205 & Field blank & $<.005$ & $<.006$ & $<.07$ & $<.018$ & $<.005$ & $<.010$ \\
\hline 31 & $10 / 21 / 1999$ & 1105 & Field blank & $<.005$ & $<.006$ & $<.07$ & $<.018$ & $<.005$ & $<.010$ \\
\hline
\end{tabular}

2 Compound detected in one or more ground-water samples.

${ }^{3}$ Compound was analyzed by the high-performance liquid chromatography/mass spectrometry method before its final approval by the U.S. Geological Survey Office of Water Quality in 2001. Although the analytical method did not change following approval, data analyzed before method approval are considered provisional. Five of the six field-blank samples analyzed with this method exceeded the recommended 4-day holding time prior to sample extraction (Furlong and others, 2001). Degradation of pesticides during extended sample storage is likely, and concentrations and detection frequencies for the pesticides analyzed by this method may be biased low. 
Table 18. Quality-control data for selected volatile organic compounds in blank water, 1999

[Well identifier corresponds to site shown in figure 3 and listed in table 6; numbers in bold indicate detection in the field-blank sample; number below the parameter name is the U.S. Geological Survey National Water Information System parameter code; concentration reported in micrograms per liter; <, less than; SS blank, source-solution blank; E, estimated value; M, presence of constituent is verified but not quantified]

\begin{tabular}{|c|c|c|c|c|c|c|c|c|c|}
\hline $\begin{array}{c}\text { Well } \\
\text { identifier }\end{array}$ & Sample date & $\begin{array}{c}\text { Sample } \\
\text { time }\end{array}$ & Sample type & $\begin{array}{c}\text { Benzene }^{1} \\
(34030)\end{array}$ & $\begin{array}{c}\text { Bromodichloro- } \\
\text { methane }^{1} \\
(32101)\end{array}$ & $\begin{array}{c}\text { Carbon } \\
\text { disulfide }^{2} \\
(77041)\end{array}$ & $\begin{array}{c}\text { Chloroform }{ }^{1} \\
\quad(32106)\end{array}$ & $\begin{array}{c}\text { Chloro- } \\
\text { methane }^{1} \\
(34418)\end{array}$ & $\begin{array}{c}\text { 1,1-Dichloro- } \\
\text { ethane }^{1} \\
(34496)\end{array}$ \\
\hline $26 \mathrm{D}$ & $08 / 10 / 1999$ & 1605 & Field blank & $<0.10$ & $<0.05$ & $<0.37$ & $<0.05$ & $<0.2$ & $<0.07$ \\
\hline $26 \mathrm{D}$ & 08/10/1999 & 1613 & SS blank & $<.10$ & $<.05$ & $<.37$ & $<.05$ & $<.2$ & $<.07$ \\
\hline $26 \mathrm{~S}$ & 09/15/1999 & 1105 & Field blank & $<.10$ & $<.05$ & E.20 & $<.05$ & $<.2$ & $<.07$ \\
\hline $26 \mathrm{~S}$ & 09/15/1999 & 1108 & Trip blank & $<.10$ & $<.05$ & $<.37$ & $<.05$ & $<.2$ & $<.07$ \\
\hline $26 \mathrm{~S}$ & 09/15/1999 & 1113 & SS blank & $<.10$ & $<.05$ & $<.37$ & $<.05$ & $<.2$ & $<.07$ \\
\hline 1 & 09/22/1999 & 1005 & Field blank & $<.04$ & $<.05$ & $<.07$ & $<.05$ & $<.5$ & $<.07$ \\
\hline 1 & 09/22/1999 & 1013 & SS blank & $<.04$ & $<.05$ & $<.07$ & $<.05$ & $<.5$ & $<.07$ \\
\hline 22 & 09/29/1999 & 1105 & Field blank & $<.04$ & $<.05$ & $<.07$ & $<.05$ & $<.5$ & $<.07$ \\
\hline 22 & 09/29/1999 & 1113 & SS blank & $<.04$ & $<.05$ & $<.07$ & $<.05$ & $<.5$ & $<.07$ \\
\hline 10 & $10 / 13 / 1999$ & 1205 & Field blank & $<.04$ & $<.05$ & $<.07$ & $<.05$ & $<.5$ & $<.07$ \\
\hline 31 & $10 / 21 / 1999$ & 1105 & Field blank & $<.04$ & $<.05$ & $<.07$ & $<.05$ & $<.5$ & $<.07$ \\
\hline 31 & $10 / 21 / 1999$ & 1113 & SS blank & $<.04$ & $<.05$ & $<.07$ & $<.05$ & $<.5$ & $<.07$ \\
\hline $\begin{array}{c}\text { Well } \\
\text { identifier }\end{array}$ & Sample date & $\begin{array}{c}\text { Sample } \\
\text { time }\end{array}$ & Sample type & $\begin{array}{c}\text { Tetrachloro- } \\
\text { ethylene }^{1} \\
\text { (PCE) } \\
\text { (34475) }\end{array}$ & $\begin{array}{c}\text { Tetrachloro- } \\
\text { methane }^{1} \\
(32102)\end{array}$ & $\begin{array}{c}\text { Toluene }^{1} \\
(34010)\end{array}$ & $\begin{array}{c}\text { 1,1,1-Trichloro- } \\
\text { ethane }{ }^{1} \\
\text { (TCA) } \\
(34506)\end{array}$ & $\begin{array}{c}\text { Trichloro- } \\
\text { ethylene }{ }^{1} \\
\text { (TCE) } \\
(39180)\end{array}$ & $\begin{array}{c}\text { Trichloro- } \\
\text { fluoromethane } \\
\text { (CFC-11) }^{1} \\
(34488)\end{array}$ \\
\hline $26 \mathrm{D}$ & $08 / 10 / 1999$ & 1605 & Field blank & $<.1$ & $<.09$ & $<.05$ & $<.03$ & $<.04$ & $<.09$ \\
\hline $26 \mathrm{D}$ & 08/10/1999 & 1613 & SS blank & $<.1$ & $<.09$ & $<.05$ & $<.03$ & $<.04$ & $<.09$ \\
\hline $26 \mathrm{~S}$ & 09/15/1999 & 1105 & Field blank & $<.1$ & $<.09$ & $<.05$ & $<.03$ & $<.04$ & $<.09$ \\
\hline $26 \mathrm{~S}$ & 09/15/1999 & 1108 & Trip blank & $<.1$ & $<.09$ & $<.05$ & $<.03$ & $<.04$ & $<.09$ \\
\hline $26 \mathrm{~S}$ & 09/15/1999 & 1113 & SS blank & $<.1$ & $<.09$ & $<.05$ & $<.03$ & $<.04$ & $<.09$ \\
\hline 1 & 09/22/1999 & 1005 & Field blank & $<.1$ & $<.06$ & $<.05$ & $<.03$ & $<.04$ & $<.09$ \\
\hline 1 & 09/22/1999 & 1013 & SS blank & $<.1$ & $<.06$ & $<.05$ & $<.03$ & $<.04$ & $<.09$ \\
\hline 22 & 09/29/1999 & 1105 & Field blank & $<.1$ & $<.06$ & $<.05$ & $<.03$ & $<.04$ & $<.09$ \\
\hline 22 & 09/29/1999 & 1113 & SS blank & $<.1$ & $<.06$ & $<.05$ & $<.03$ & $<.04$ & $<.09$ \\
\hline 10 & $10 / 13 / 1999$ & 1205 & Field blank & $<.1$ & $<.06$ & $<.05$ & $<.03$ & $<.04$ & $<.09$ \\
\hline 31 & $10 / 21 / 1999$ & 1105 & Field blank & $<.1$ & $<.06$ & $<.05$ & $<.03$ & $<.04$ & $<.09$ \\
\hline 31 & $10 / 21 / 1999$ & 1113 & SS blank & $<.1$ & $<.06$ & $<.05$ & $<.03$ & $<.04$ & $<.09$ \\
\hline
\end{tabular}

${ }^{2}$ Compound detected in one or more ground-water and field-blank samples. 
Table 18. Quality-control data for selected volatile organic compounds in blank water, 1999—Continued

\begin{tabular}{|c|c|c|c|c|c|c|c|c|c|}
\hline $\begin{array}{c}\text { Well } \\
\text { identifier }\end{array}$ & Sample date & $\begin{array}{c}\text { Sample } \\
\text { time }\end{array}$ & Sample type & $\begin{array}{c}\text { 1,2-Dichloro- } \\
\text { ethane }^{1} \\
(32103)\end{array}$ & $\begin{array}{l}\text { 1,1-Dichloro- } \\
\text { ethylene }^{1} \\
(34501)\end{array}$ & $\begin{array}{c}\text { Dichloro- } \\
\text { methane }{ }^{1} \\
(34423)\end{array}$ & $\begin{array}{c}\text { Ethyl- } \\
\text { benzene }^{2} \\
\text { (34371) }\end{array}$ & $\begin{array}{c}\text { o-Ethyl- } \\
\text { toluene }^{2} \\
(77220)\end{array}$ & $\begin{array}{c}\text { Methyl tert- } \\
\text { butyl ether } \\
\text { (MTBE) }^{1} \\
\text { (78032) }\end{array}$ \\
\hline $26 \mathrm{D}$ & 08/10/1999 & 1605 & Field blank & $<0.1$ & $<0.04$ & $<0.4$ & E0.03 & E0.01 & $<0.2$ \\
\hline $26 \mathrm{D}$ & 08/10/1999 & 1613 & SS blank & $<.1$ & $<.04$ & $<.4$ & $<.03$ & $<.10$ & $<.2$ \\
\hline $26 \mathrm{~S}$ & 09/15/1999 & 1105 & Field blank & $<.1$ & $<.04$ & $<.4$ & E.02 & $<.10$ & $<.2$ \\
\hline $26 \mathrm{~S}$ & 09/15/1999 & 1108 & Trip blank & $<.1$ & $<.04$ & $<.4$ & $<.03$ & $<.10$ & $<.2$ \\
\hline $26 \mathrm{~S}$ & 09/15/1999 & 1113 & SS blank & $<.1$ & $<.04$ & $<.4$ & $<.03$ & $<.10$ & $<.2$ \\
\hline 1 & 09/22/1999 & 1005 & Field blank & $<.1$ & $<.04$ & $<.4$ & $<.03$ & $<.06$ & $<.2$ \\
\hline 1 & 09/22/1999 & 1013 & SS blank & $<.1$ & $<.04$ & $<.4$ & $<.03$ & $<.06$ & $<.2$ \\
\hline 22 & 09/29/1999 & 1105 & Field blank & $<.1$ & $<.04$ & $<.4$ & E.01 & $\mathbf{M}$ & $<.2$ \\
\hline 22 & 09/29/1999 & 1113 & SS blank & $<.1$ & $<.04$ & $<.4$ & $<.03$ & $<.06$ & $<.2$ \\
\hline 10 & $10 / 13 / 1999$ & 1205 & Field blank & $<.1$ & $<.04$ & $<.4$ & $<.03$ & $<.06$ & $<.2$ \\
\hline 31 & $10 / 21 / 1999$ & 1105 & Field blank & $<.1$ & $<.04$ & $<.4$ & $<.03$ & $<.06$ & $<.2$ \\
\hline 31 & $10 / 21 / 1999$ & 1113 & SS blank & $<.1$ & $<.04$ & $<.4$ & $<.03$ & $<.06$ & $<.2$ \\
\hline $\begin{array}{c}\text { Well } \\
\text { identifier }\end{array}$ & Sample date & $\begin{array}{l}\text { Sample } \\
\text { time }\end{array}$ & Sample type & $\begin{array}{c}\text { 1,1,2-Trichloro- } \\
\text { trifluoroethane } \\
\text { (CFC-113) }^{1} \\
(77652)\end{array}$ & $\begin{array}{c}1,2,3- \\
\text { Trimethyl- } \\
\text { benzene }^{2} \\
(77221)\end{array}$ & $\begin{array}{c}\text { 1,2,4-Trimethyl- } \\
\text { benzene }^{2} \\
\text { (77222) }\end{array}$ & $\begin{array}{c}\text { 1,3,5-Trimethyl- } \\
\text { benzene } \\
\text { (77226) }\end{array}$ & $\begin{array}{c}\text { m- and p- } \\
\text { Xylene }^{2} \\
(85795)\end{array}$ & $\begin{array}{c}\text { o-Xylene } \\
\text { (77135) }\end{array}$ \\
\hline $26 \mathrm{D}$ & $08 / 10 / 1999$ & 1605 & Field blank & $<.03$ & $\mathbf{M}$ & E.06 & E.02 & E.15 & $\mathbf{E . 0 3}$ \\
\hline $26 \mathrm{D}$ & 08/10/1999 & 1613 & SS blank & $<.03$ & $<.1$ & $<.06$ & $<.04$ & $<.06$ & $<.06$ \\
\hline $26 \mathrm{~S}$ & 09/15/1999 & 1105 & Field blank & $<.03$ & $<.1$ & $<.06$ & $<.04$ & E.10 & $<.06$ \\
\hline $26 \mathrm{~S}$ & 09/15/1999 & 1108 & Trip blank & $<.03$ & $<.1$ & $<.06$ & $<.04$ & $<.06$ & $<.06$ \\
\hline $26 \mathrm{~S}$ & 09/15/1999 & 1113 & SS blank & $<.03$ & $<.1$ & $<.06$ & $<.04$ & $<.06$ & $<.06$ \\
\hline 1 & 09/22/1999 & 1005 & Field blank & $<.06$ & $<.1$ & $<.06$ & $<.04$ & E.03 & $<.04$ \\
\hline 1 & 09/22/1999 & 1013 & SS blank & $<.06$ & $<.1$ & $<.06$ & $<.04$ & $<.06$ & $<.04$ \\
\hline 22 & 09/29/1999 & 1105 & Field blank & $<.06$ & $<.1$ & $<.06$ & $<.04$ & E.03 & $<.04$ \\
\hline 22 & 09/29/1999 & 1113 & SS blank & $<.06$ & $<.1$ & $<.06$ & $<.04$ & $<.06$ & $<.04$ \\
\hline 10 & $10 / 13 / 1999$ & 1205 & Field blank & $<.06$ & $<.1$ & $<.06$ & $<.04$ & $<.06$ & $<.04$ \\
\hline 31 & $10 / 21 / 1999$ & 1105 & Field blank & $<.06$ & $<.1$ & E.01 & $<.04$ & E.04 & $<.04$ \\
\hline 31 & $10 / 21 / 1999$ & 1113 & SS blank & $<.06$ & $<.1$ & $<.06$ & $<.04$ & $<.06$ & $<.04$ \\
\hline
\end{tabular}


Table 19. Percent recovery for pesticide surrogates in blank water and water sampled from monitoring wells in Salt Lake Valley, Utah, 1999

[Well identifier corresponds to site shown in figure 3 and listed in table 6; number below the parameter name is the U.S. Geological Survey National Water Information System parameter code; all surrogate recoveries are reported in percent; E, estimated value]

\begin{tabular}{|c|c|c|c|c|c|c|c|c|}
\hline $\begin{array}{c}\text { Well } \\
\text { identifier }\end{array}$ & Sample date & $\begin{array}{c}\text { Sample } \\
\text { time }\end{array}$ & Sample type & $\begin{array}{c}\text { alpha-HCH-d6 } \\
\text { (91065) }\end{array}$ & $\begin{array}{l}\text { Barban } \\
(90640)\end{array}$ & $\begin{array}{c}\text { Caffeine }^{1} \\
\text { (99959) }\end{array}$ & $\begin{array}{c}\text { Diazinon } \\
\text { (91063) }\end{array}$ & $\begin{array}{l}2,4,5-\mathrm{T}^{1} \\
(99958)\end{array}$ \\
\hline $26 \mathrm{D}$ & 08/10/1999 & 1605 & Field blank & 102 & 81 & 102 & 101 & 96 \\
\hline $26 \mathrm{~S}$ & 09/15/1999 & 1105 & Field blank & E175 & E72 & 87 & E197 & 48 \\
\hline 1 & 09/22/1999 & 1005 & Field blank & 91 & 73 & E107 & 111 & 61 \\
\hline 22 & 09/29/1999 & 1105 & Field blank & 72 & E80 & E101 & 97 & 73 \\
\hline 10 & 10/13/1999 & 1205 & Field blank & 99 & 89 & 50 & 134 & 47 \\
\hline 31 & 10/21/1999 & 1105 & Field blank & 88 & 59 & E80 & 124 & 59 \\
\hline 1 & 09/22/1999 & 1000 & Ground water & 83 & 91 & E99 & 105 & 64 \\
\hline 2 & 09/20/1999 & 1400 & Ground water & 73 & E94 & 70 & 90 & 58 \\
\hline 3 & $10 / 19 / 1999$ & 1100 & Ground water & 84 & 82 & 77 & 125 & 60 \\
\hline 4 & 09/20/1999 & 1000 & Ground water & 89 & E89 & 71 & 108 & 66 \\
\hline 5 & 09/27/1999 & 1100 & Ground water & 92 & E76 & E81 & 95 & 66 \\
\hline 6 & 10/07/1999 & 1100 & Ground water & 102 & 75 & 89 & 141 & 48 \\
\hline 7 & 09/28/1999 & 1400 & Ground water & 83 & E84 & E90 & 96 & 73 \\
\hline 8 & 10/18/1999 & 1200 & Ground water & 92 & 41 & 76 & 133 & 50 \\
\hline 9 & 09/28/1999 & 1000 & Ground water & 90 & E78 & E86 & 100 & 71 \\
\hline 10 & 10/13/1999 & 1200 & Ground water & 89 & 83 & 44 & 120 & 43 \\
\hline 11 & 10/06/1999 & 1000 & Ground water & 89 & 73 & 68 & 124 & E35 \\
\hline 14 & 09/30/1999 & 1100 & Ground water & 79 & E83 & E87 & 111 & 66 \\
\hline 17 & 09/23/1999 & 1100 & Ground water & 84 & 107 & E90 & 97 & 62 \\
\hline 18 & 09/13/1999 & 1200 & Ground water & 97 & E104 & 78 & 101 & 60 \\
\hline 20 & 10/05/1999 & 1200 & Ground water & 80 & 72 & 80 & 118 & 54 \\
\hline 22 & 09/29/1999 & 1100 & Ground water & 78 & 62 & 82 & 107 & E43 \\
\hline 24 & 10/20/1999 & 1100 & Ground water & 84 & 53 & E64 & 113 & 58 \\
\hline 25 & $10 / 12 / 1999$ & 1400 & Ground water & 97 & 96 & 44 & 139 & 54 \\
\hline $26 \mathrm{D}$ & 08/10/1999 & 1100 & Ground water & 106 & 76 & 93 & 103 & 101 \\
\hline $26 S$ & 09/15/1999 & 1100 & Ground water & 73 & E72 & 69 & 85 & 89 \\
\hline 27 & 09/07/1999 & 1200 & Ground water & 84 & E106 & 98 & 101 & 90 \\
\hline 29 & 09/21/1999 & 1100 & Ground water & 83 & E84 & 83 & 97 & 46 \\
\hline 30 & $10 / 12 / 1999$ & 1000 & Ground water & 95 & 85 & 45 & 128 & 56 \\
\hline 31 & 10/21/1999 & 1100 & Ground water & 86 & 50 & E66 & 119 & 61 \\
\hline 32 & 09/14/1999 & 1100 & Ground water & 92 & E93 & 79 & 101 & 82 \\
\hline 33 & 10/14/1999 & 1000 & Ground water & 92 & 90 & 40 & 121 & 56 \\
\hline 34 & 090/9/1999 & 1100 & Ground water & 89 & E86 & 93 & 91 & 75 \\
\hline 37 & 09/08/1999 & 1100 & Ground water & 99 & E90 & 98 & 89 & 81 \\
\hline 39 & 10/04/1999 & 1100 & Ground water & 88 & 60 & 81 & 123 & E50 \\
\hline 41 & 09/16/1999 & 1100 & Ground water & 85 & E80 & 70 & 102 & 62 \\
\hline
\end{tabular}
Geological Survey Office of Water Quality in 2001. Although the analytical method did not change following approval, data analyzed before method approval are considered provisional. Five of the 6 field-blank samples and 27 of the 30 ground-water samples analyzed with this method exceeded the recommended 4-day holding time prior to sample extraction (Furlong and others, 2001). Degradation of pesticides during extended sample storage is likely, and concentrations and detection frequencies for the pesticides analyzed by this method may be biased low. 
Table 20. Percent recovery for volatile organic compound surrogates in blank water and water sampled from monitoring wells in Salt Lake Valley, Utah, 1999

[Well identifier corresponds to site shown in figure 3 and listed in table 6; number below the parameter name is the U.S. Geological Survey National Water Information System parameter code; all surrogate recoveries are reported in percent]

\begin{tabular}{|c|c|c|c|c|c|c|}
\hline $\begin{array}{c}\text { Well } \\
\text { identifier }\end{array}$ & Sample date & $\begin{array}{c}\text { Sample } \\
\text { time }\end{array}$ & Sample type & $\begin{array}{c}\text { 1,2-Dichloro- } \\
\text { ethane-d4 } \\
\text { (99832) }\end{array}$ & $\begin{array}{c}\text { 1,4-Bromofluoro- } \\
\text { benzene } \\
\text { (99834) }\end{array}$ & $\begin{array}{c}\text { Toluene-d8 } \\
\text { (99833) }\end{array}$ \\
\hline $26 \mathrm{D}$ & $08 / 10 / 1999$ & 1605 & Field blank & 99 & 86 & 94 \\
\hline $26 \mathrm{D}$ & 08/10/1999 & 1613 & Source-solution blank & 97 & 85 & 95 \\
\hline $26 \mathrm{~S}$ & 09/15/1999 & 1105 & Field blank & 117 & 97 & 102 \\
\hline $26 \mathrm{~S}$ & 09/15/1999 & 1108 & Trip blank & 112 & 92 & 100 \\
\hline $26 \mathrm{~S}$ & 09/15/1999 & 1113 & Source-solution blank & 113 & 91 & 98 \\
\hline 1 & 09/22/1999 & 1005 & Field blank & 119 & 97 & 103 \\
\hline 1 & 09/22/1999 & 1013 & Source-solution blank & 112 & 98 & 104 \\
\hline 22 & 09/29/1999 & 1105 & Field blank & 96 & 97 & 102 \\
\hline 22 & 09/29/1999 & 1113 & Source-solution blank & 95 & 97 & 102 \\
\hline 10 & $10 / 13 / 1999$ & 1205 & Field blank & 105 & 86 & 95 \\
\hline 31 & $10 / 21 / 1999$ & 1105 & Field blank & 115 & 101 & 94 \\
\hline 31 & $10 / 21 / 1999$ & 1113 & Source-solution blank & 113 & 101 & 96 \\
\hline 1 & 09/22/1999 & 1000 & Ground water & 116 & 95 & 103 \\
\hline 2 & 09/20/1999 & 1400 & Ground water & 109 & 100 & 103 \\
\hline 3 & $10 / 19 / 1999$ & 1100 & Ground water & 109 & 73 & 93 \\
\hline 4 & 09/20/1999 & 1000 & Ground water & 112 & 99 & 103 \\
\hline 5 & 09/27/1999 & 1100 & Ground water & 97 & 98 & 102 \\
\hline 6 & 10/07/1999 & 1100 & Ground water & 118 & 99 & 103 \\
\hline 7 & 09/28/1999 & 1400 & Ground water & 95 & 96 & 101 \\
\hline 8 & $10 / 18 / 1999$ & 1200 & Ground water & 108 & 74 & 95 \\
\hline 9 & 09/28/1999 & 1000 & Ground water & 96 & 99 & 102 \\
\hline 10 & $10 / 13 / 1999$ & 1200 & Ground water & 105 & 77 & 94 \\
\hline 11 & $10 / 06 / 1999$ & 1000 & Ground water & 118 & 88 & 101 \\
\hline 14 & 09/30/1999 & 1100 & Ground water & 96 & 97 & 100 \\
\hline 17 & 09/23/1999 & 1100 & Ground water & 121 & 101 & 104 \\
\hline 18 & 09/13/1999 & 1200 & Ground water & 90 & 98 & 102 \\
\hline 20 & $10 / 05 / 1999$ & 1200 & Ground water & 112 & 98 & 99 \\
\hline 22 & 09/29/1999 & 1100 & Ground water & 95 & 95 & 101 \\
\hline 24 & $10 / 20 / 1999$ & 1100 & Ground water & 113 & 100 & 91 \\
\hline 25 & $10 / 12 / 1999$ & 1400 & Ground water & 107 & 89 & 96 \\
\hline $26 \mathrm{D}$ & 08/10/1999 & 1100 & Ground water & 98 & 84 & 94 \\
\hline $26 \mathrm{~S}$ & 09/15/1999 & 1100 & Ground water & 114 & 95 & 99 \\
\hline 27 & 09/07/1999 & 1200 & Ground water & 95 & 98 & 101 \\
\hline 29 & 09/21/1999 & 1100 & Ground water & 107 & 102 & 109 \\
\hline 30 & $10 / 12 / 1999$ & 1000 & Ground water & 109 & 79 & 93 \\
\hline 31 & 10/21/1999 & 1100 & Ground water & 118 & 105 & 96 \\
\hline 32 & 09/14/1999 & 1100 & Ground water & 88 & 99 & 104 \\
\hline 33 & $10 / 14 / 1999$ & 1000 & Ground water & 110 & 73 & 95 \\
\hline 34 & 09/09/1999 & 1100 & Ground water & 91 & 103 & 104 \\
\hline 37 & 09/08/1999 & 1100 & Ground water & 93 & 99 & 102 \\
\hline 39 & 10/04/1999 & 1100 & Ground water & 109 & 87 & 98 \\
\hline 41 & 09/16/1999 & 1100 & Ground water & 104 & 100 & 100 \\
\hline
\end{tabular}


Table 21. Percent recovery for matrix spikes of pesticides in water sampled from monitoring wells in Salt Lake Valley, Utah, 1999

[Parameter code is used in U.S. Geological Survey National Water Information System database; —, no data]

\begin{tabular}{|c|c|c|c|c|c|c|}
\hline \multirow[b]{2}{*}{$\begin{array}{l}\text { Parameter } \\
\text { code }\end{array}$} & \multirow[b]{2}{*}{ Compound } & \multicolumn{5}{|c|}{ Recovery (percent) } \\
\hline & & $\begin{array}{c}\text { Matrix spike } \\
09 / 09 / 99\end{array}$ & $\begin{array}{c}\text { Matrix spike } \\
\text { 10/04/99 }\end{array}$ & $\begin{array}{c}\text { Matrix-spike } \\
\text { replicate } \\
10 / 04 / 99\end{array}$ & $\begin{array}{c}\text { Matrix spike } \\
10 / 19 / 99\end{array}$ & $\begin{array}{c}\text { Matrix-spike } \\
\text { replicate } \\
10 / 19 / 99\end{array}$ \\
\hline \multicolumn{7}{|c|}{ Gas Chromatography/Mass Spectrometry analytical method } \\
\hline 49260 & Acetochlor & 109 & 104 & 101 & 107 & 102 \\
\hline 46342 & Alachlor & 92 & 107 & 102 & 104 & 103 \\
\hline 39632 & Atrazine & 89 & 86 & 82 & 93 & 93 \\
\hline 82686 & Azinphos-methyl & 198 & 106 & 99 & 115 & 100 \\
\hline 82673 & Benfluralin & 78 & 68 & 67 & 64 & 61 \\
\hline 04028 & Butylate & 95 & 112 & 114 & 93 & 93 \\
\hline 82680 & Carbaryl & 314 & 213 & 210 & 238 & 253 \\
\hline 82674 & Carbofuran & 164 & 192 & 187 & 199 & 199 \\
\hline 38933 & Chlorpyrifos & 83 & 84 & 79 & 89 & 86 \\
\hline 04041 & Cyanazine & 106 & 81 & 77 & 78 & 73 \\
\hline 82682 & Dacthal & 102 & 76 & 72 & 73 & 73 \\
\hline 34653 & p,p'-DDE & 85 & 92 & 83 & 93 & 89 \\
\hline 04040 & Deethylatrazine & 31 & 39 & 24 & 31 & 28 \\
\hline 39572 & Diazinon & 85 & 113 & 110 & 122 & 115 \\
\hline 39381 & Dieldrin & 108 & 123 & 116 & 112 & 109 \\
\hline 82660 & 2,6-Diethylaniline & 75 & 130 & 129 & 142 & 133 \\
\hline 82677 & Disulfoton & 56 & 61 & 60 & 71 & 68 \\
\hline 82668 & EPTC & 95 & 92 & 93 & 98 & 99 \\
\hline 82663 & Ethalfluralin & 93 & 94 & 88 & 91 & 91 \\
\hline 82672 & Ethoprophos & 86 & 71 & 70 & 69 & 63 \\
\hline 04095 & Fonofos & 103 & 91 & 85 & 97 & 92 \\
\hline 34253 & alpha-HCH & 83 & 104 & 98 & 109 & 109 \\
\hline 39341 & Lindane & 91 & 99 & 93 & 118 & 105 \\
\hline 82666 & Linuron & 218 & 163 & 158 & 150 & 137 \\
\hline 39532 & Malathion & 108 & 90 & 88 & 85 & 80 \\
\hline 39415 & Metolachlor & 116 & 101 & 97 & 96 & 95 \\
\hline 82630 & Metribuzin & 88 & 114 & 100 & 105 & 105 \\
\hline 82671 & Molinate & 90 & 101 & 103 & 100 & 103 \\
\hline 82684 & Napropamide & 98 & 107 & 101 & 98 & 89 \\
\hline 39542 & Parathion & 110 & 112 & 117 & 110 & 98 \\
\hline 82667 & Parathion-methyl & 118 & 140 & 142 & 128 & 120 \\
\hline 82669 & Pebulate & 93 & 92 & 94 & 96 & 95 \\
\hline 82683 & Pendimethalin & 102 & 119 & 121 & 105 & 100 \\
\hline 82687 & cis-Permethrin & 79 & 86 & 80 & 95 & 89 \\
\hline 82664 & Phorate & 63 & 75 & 73 & 82 & 86 \\
\hline 04037 & Prometon & 88 & 98 & 95 & 103 & 94 \\
\hline 04024 & Propachlor & 107 & 99 & 107 & 102 & 102 \\
\hline 82679 & Propanil & 117 & 95 & 93 & 93 & 86 \\
\hline 82685 & Propargite & 105 & 82 & 78 & 84 & 93 \\
\hline 82676 & Propyzamide & 95 & 90 & 85 & 85 & 82 \\
\hline 04035 & Simazine & 115 & 93 & 88 & 92 & 88 \\
\hline 82670 & Tebuthiuron & 90 & 90 & 96 & 89 & 86 \\
\hline 82665 & Terbacil & 159 & 143 & 120 & 163 & 161 \\
\hline 82675 & Terbufos & 76 & 69 & 67 & 70 & 64 \\
\hline 82681 & Thiobencarb & 102 & 94 & 95 & 99 & 91 \\
\hline 82678 & Triallate & 92 & 91 & 87 & 95 & 94 \\
\hline 82661 & Trifluralin & 77 & 63 & 64 & 64 & 61 \\
\hline
\end{tabular}


Table 21. Percent recovery for matrix spikes of pesticides in water sampled from monitoring wells in Salt Lake Valley, Utah, 1999—Continued

\begin{tabular}{|c|c|c|c|c|c|c|}
\hline \multirow[b]{2}{*}{$\begin{array}{l}\text { Parameter } \\
\text { code }\end{array}$} & \multirow[b]{2}{*}{ Compound } & \multicolumn{5}{|c|}{ Recovery (percent) } \\
\hline & & $\begin{array}{c}\text { Matrix spike } \\
09 / 09 / 99\end{array}$ & $\begin{array}{c}\text { Matrix spike } \\
10 / 04 / 99\end{array}$ & $\begin{array}{c}\text { Matrix-spike } \\
\text { replicate } \\
10 / 04 / 99\end{array}$ & $\begin{array}{c}\text { Matrix spike } \\
10 / 19 / 99\end{array}$ & $\begin{array}{c}\text { Matrix-spike } \\
\text { replicate } \\
10 / 19 / 99\end{array}$ \\
\hline \multicolumn{7}{|c|}{ High-Performance Liquid Chromatography analytical method ${ }^{1}$} \\
\hline 39732 & $2,4-\mathrm{D}$ & 74 & 37 & 42 & 57 & 57 \\
\hline 50470 & 2,4-D methyl ester & 79 & 52 & 54 & 43 & 56 \\
\hline 38746 & $2,4-\mathrm{DB}$ & 69 & 24 & 42 & 39 & 43 \\
\hline 50355 & 2-Hydroxyatrazine & 165 & 122 & 131 & 132 & 134 \\
\hline 61692 & 3(4-Chlorophenyl)-1-methyl urea & 88 & 85 & 81 & 69 & 49 \\
\hline 49308 & 3-Hydroxycarbofuran & 112 & 85 & 84 & 64 & 69 \\
\hline 50295 & 3-Ketocarbofuran & 99 & 47 & 65 & 34 & 20 \\
\hline 49315 & Acifluorfen & 71 & 75 & 69 & 73 & 74 \\
\hline 49313 & Aldicarb sulfone & 50 & 6 & 4 & 23 & 22 \\
\hline 49314 & Aldicarb sulfoxide & 52 & 29 & 27 & 26 & 42 \\
\hline 39632 & Atrazine & 37 & 34 & 33 & 37 & 37 \\
\hline 50299 & Bendiocarb & 96 & 71 & 73 & 33 & 37 \\
\hline 50300 & Benomyl & 105 & 81 & 84 & 47 & 56 \\
\hline 61693 & Bensulfuron-methyl & 137 & 108 & 113 & 80 & 89 \\
\hline 38711 & Bentazon & 51 & 63 & 50 & 69 & 71 \\
\hline 04029 & Bromacil & 81 & 61 & 59 & 53 & 54 \\
\hline 49311 & Bromoxynil & 88 & 60 & 59 & 80 & 79 \\
\hline 50305 & Caffeine & 96 & 83 & 84 & 70 & 79 \\
\hline 49310 & Carbaryl & 87 & 85 & 86 & 70 & 76 \\
\hline 49309 & Carbofuran & 102 & 93 & 96 & 73 & 79 \\
\hline 61188 & Chloramben, methyl ester & 75 & 73 & 60 & 65 & 63 \\
\hline 50306 & Chlorimuron-ethyl & 132 & 109 & 108 & 76 & 87 \\
\hline 49306 & Chlorothalonil & 61 & 50 & 30 & 57 & 54 \\
\hline 49305 & Clopyralid & 61 & 59 & 46 & 79 & 73 \\
\hline 04031 & Cycloate & 94 & 73 & 78 & 51 & 59 \\
\hline 49304 & Dacthal monoacid & 78 & 62 & 52 & 75 & 72 \\
\hline 04040 & Deethylatrazine & 13 & 15 & 10 & 12 & 11 \\
\hline 04039 & Deethyldeisopropylatrazine & 94 & 77 & 7 & 79 & 92 \\
\hline 04038 & Deisopropylatrazine & 41 & 23 & 25 & 23 & 19 \\
\hline 38442 & Dicamba & 84 & 54 & 43 & 94 & 88 \\
\hline 49302 & Dichlorprop & 90 & 48 & 54 & 65 & 65 \\
\hline 49301 & Dinoseb & 94 & 61 & 58 & 80 & 79 \\
\hline 04033 & Diphenamid & 87 & 77 & 75 & 58 & 63 \\
\hline 49300 & Diuron & 76 & 84 & 85 & 58 & 64 \\
\hline 49297 & Fenuron & 56 & 58 & 69 & 56 & 72 \\
\hline 61694 & Flumetsulam & 217 & - & - & 123 & 140 \\
\hline 38811 & Fluometuron & 88 & 82 & 82 & 63 & 69 \\
\hline 50356 & Imazaquin & 180 & 120 & 122 & 51 & 55 \\
\hline 50407 & Imazethapyr & - & 120 & 129 & 111 & 101 \\
\hline 61695 & Imidacloprid & 181 & 131 & 131 & 101 & 113 \\
\hline 38478 & Linuron & 100 & 88 & 82 & 67 & 74 \\
\hline 38482 & MCPA & 78 & 40 & 47 & 51 & 52 \\
\hline 38487 & МCPB & 61 & 27 & 41 & 40 & 39 \\
\hline 50359 & Metalaxyl & 90 & 83 & 82 & 59 & 66 \\
\hline 38501 & Methiocarb & 96 & 83 & 85 & 67 & 74 \\
\hline 49296 & Methomyl & 81 & 80 & 85 & 67 & 79 \\
\hline 49294 & Neburon & 101 & 84 & 84 & 39 & 41 \\
\hline 50364 & Nicosulfuron & 218 & 205 & 198 & 102 & 107 \\
\hline 49293 & Norflurazon & 106 & 93 & 93 & 67 & 72 \\
\hline 49292 & Oryzalin & 87 & 66 & 54 & 50 & 56 \\
\hline 38866 & Oxamyl & 81 & 78 & 76 & 49 & 56 \\
\hline
\end{tabular}


Table 21. Percent recovery for matrix spikes of pesticides in water sampled from monitoring wells in Salt Lake Valley, Utah, 1999—Continued

\begin{tabular}{|c|c|c|c|c|c|c|}
\hline \multirow[b]{2}{*}{$\begin{array}{c}\text { Parameter } \\
\text { code }\end{array}$} & \multirow[b]{2}{*}{ Compound } & \multicolumn{5}{|c|}{ Recovery (percent) } \\
\hline & & $\begin{array}{c}\text { Matrix spike } \\
09 / 09 / 99\end{array}$ & $\begin{array}{c}\text { Matrix spike } \\
\text { 10/04/99 }\end{array}$ & $\begin{array}{c}\text { Matrix-spike } \\
\text { replicate } \\
10 / 04 / 99\end{array}$ & $\begin{array}{c}\text { Matrix spike } \\
\text { 10/19/99 }\end{array}$ & $\begin{array}{c}\text { Matrix-spike } \\
\text { replicate } \\
10 / 19 / 99\end{array}$ \\
\hline \multicolumn{7}{|c|}{ High-Performance Liquid Chromatography analytical method ${ }^{1}$-Continued } \\
\hline 49291 & Picloram & 105 & 65 & 71 & 84 & 66 \\
\hline 49236 & Propham & 107 & 87 & 86 & 86 & 91 \\
\hline 50471 & Propiconazole & 95 & 92 & 94 & 45 & 49 \\
\hline 38538 & Propoxur & 91 & 80 & 78 & 63 & 67 \\
\hline 38548 & Siduron & 100 & 87 & 84 & 67 & 72 \\
\hline 50337 & Sulfometuron-methyl & 145 & 124 & 121 & 73 & 75 \\
\hline 82670 & Tebuthiuron & 37 & 36 & 39 & 36 & 34 \\
\hline 04032 & Terbacil & 83 & 73 & 71 & 72 & 78 \\
\hline 49235 & Triclopyr & 79 & 44 & 47 & 53 & 61 \\
\hline
\end{tabular}

${ }^{1}$ The samples from this study were analyzed by the high-performance liquid chromatography/mass spectrometry method before its final approval by the U.S. Geological Survey Office of Water Quality in 2001. Although the analytical method did not change following approval, data analyzed before method approval are considered provisional. All of the spiked samples analyzed with this method in this study exceeded the recommended 4-day holding time prior to sample extraction (Furlong and others, 2001). Degradation of pesticides during extended sample storage is likely, and concentrations and detection frequencies for the pesticides analyzed by this method may be biased low. 
Table 22. Percent recovery for matrix spikes of volatile organic compounds in water sampled from monitoring wells in Salt Lake Valley, Utah, 1999

[Parameter code is used in U.S. Geological Survey National Water Information System database]

\begin{tabular}{|c|c|c|c|c|c|c|c|}
\hline \multirow[b]{2}{*}{$\begin{array}{l}\text { Parameter } \\
\text { code }\end{array}$} & \multirow[b]{2}{*}{ Compound } & \multicolumn{6}{|c|}{ Recovery (percent) } \\
\hline & & $\begin{array}{c}\text { Matrix spike } \\
09 / 09 / 99\end{array}$ & $\begin{array}{c}\text { Matrix-spike } \\
\text { replicate } \\
09 / 09 / 99\end{array}$ & $\begin{array}{c}\text { Matrix spike } \\
10 / 04 / 99\end{array}$ & $\begin{array}{c}\text { Matrix-spike } \\
\text { replicate } \\
10 / 04 / 99\end{array}$ & $\begin{array}{c}\text { Matrix spike } \\
10 / 19 / 99\end{array}$ & $\begin{array}{c}\text { Matrix-spike } \\
\text { replicate } \\
10 / 19 / 99\end{array}$ \\
\hline 81552 & Acetone & 106 & 106 & 116 & 109 & 102 & 111 \\
\hline 34215 & Acrylonitrile & 103 & 105 & 94 & 105 & 104 & 99 \\
\hline 34030 & Benzene & 100 & 100 & 80 & 86 & 84 & 85 \\
\hline 81555 & Bromobenzene & 67 & 86 & 53 & 77 & 81 & 57 \\
\hline 77297 & Bromochloromethane & 90 & 92 & 87 & 83 & 85 & 91 \\
\hline 32101 & Bromodichloromethane & 130 & 110 & 97 & 116 & 98 & 91 \\
\hline 50002 & Bromoethene & 56 & 49 & 45 & 44 & 36 & 40 \\
\hline 32104 & Bromoform & 90 & 92 & 91 & 84 & 91 & 85 \\
\hline 34413 & Bromomethane & 115 & 73 & 55 & 58 & 52 & 55 \\
\hline 81595 & 2-Butanone & 111 & 113 & 100 & 113 & 111 & 97 \\
\hline 77342 & Butylbenzene & 90 & 87 & 72 & 75 & 68 & 71 \\
\hline 77350 & sec-Butylbenzene & 77 & 86 & 74 & 84 & 73 & 74 \\
\hline 77353 & tert-Butylbenzene & 77 & 84 & 87 & 81 & 74 & 77 \\
\hline 77041 & Carbon disulfide & 106 & 119 & 97 & 85 & 92 & 100 \\
\hline 34301 & Chlorobenzene & 85 & 94 & 69 & 83 & 81 & 77 \\
\hline 34311 & Chloroethane & 117 & 110 & 81 & 96 & 91 & 72 \\
\hline 32106 & Chloroform & 145 & 108 & 87 & 136 & 89 & 88 \\
\hline 34418 & Chloromethane & 169 & 175 & 149 & 158 & 129 & 148 \\
\hline 78109 & 3-Chloropropene & 100 & 103 & 83 & 77 & 83 & 89 \\
\hline 77275 & 2-Chlorotoluene & 70 & 73 & 60 & 68 & 69 & 61 \\
\hline 77277 & 4-Chlorotoluene & 68 & 79 & 68 & 73 & 73 & 66 \\
\hline 32105 & Dibromochloromethane & 96 & 101 & 88 & 92 & 92 & 85 \\
\hline 82625 & 1,2-Dibromo-3-chloropropane & 71 & 77 & 67 & 92 & 83 & 67 \\
\hline 77651 & 1,2-Dibromoethane & 90 & 91 & 85 & 85 & 86 & 88 \\
\hline 30217 & Dibromomethane & 90 & 95 & 82 & 90 & 86 & 81 \\
\hline 34536 & 1,2-Dichlorobenzene & 77 & 83 & 80 & 87 & 75 & 74 \\
\hline 34566 & 1,3-Dichlorobenzene & 76 & 77 & 71 & 79 & 73 & 68 \\
\hline 34571 & 1,4-Dichlorobenzene & 76 & 82 & 81 & 81 & 72 & 73 \\
\hline 73547 & trans-1,4-Dichloro-2-butene & 77 & 117 & 101 & 84 & 114 & 98 \\
\hline 34668 & Dichlorodifluoromethane & 140 & 137 & 101 & 95 & 86 & 94 \\
\hline 34496 & 1,1-Dichloroethane & 109 & 105 & 80 & 90 & 89 & 85 \\
\hline 32103 & 1,2-Dichloroethane & 103 & 105 & 91 & 94 & 94 & 88 \\
\hline 34501 & 1,1-Dichloroethylene & 119 & 111 & 95 & 96 & 85 & 100 \\
\hline 77093 & cis-1,2-Dichloroethylene & 94 & 94 & 65 & 82 & 75 & 79 \\
\hline 34546 & trans-1,2-Dichloroethylene & 100 & 104 & 74 & 85 & 89 & 85 \\
\hline 34423 & Dichloromethane & 93 & 89 & 83 & 80 & 74 & 83 \\
\hline 34541 & 1,2-Dichloropropane & 106 & 106 & 84 & 90 & 91 & 87 \\
\hline 77173 & 1,3-Dichloropropane & 103 & 104 & 96 & 101 & 97 & 94 \\
\hline 77170 & 2,2-Dichloropropane & 80 & 79 & 65 & 63 & 67 & 67 \\
\hline 77168 & 1,1-Dichloropropene & 102 & 98 & 67 & 82 & 79 & 76 \\
\hline 34704 & cis-1,3-Dichloropropene & 84 & 93 & 71 & 77 & 77 & 77 \\
\hline 34699 & trans-1,3-Dichloropropene & 80 & 89 & 71 & 75 & 78 & 73 \\
\hline 81576 & Diethyl ether & 93 & 107 & 96 & 87 & 94 & 100 \\
\hline 81577 & Diisopropyl ether & 88 & 100 & 71 & 82 & 90 & 76 \\
\hline 34371 & Ethylbenzene & 79 & 89 & 54 & 85 & 76 & 62 \\
\hline 73570 & Ethyl methacrylate & 80 & 107 & 74 & 79 & 100 & 79 \\
\hline 50004 & Ethyl tert-butyl ether & 94 & 99 & 60 & 86 & 83 & 74 \\
\hline 77220 & o-Ethyl toluene & 34 & 42 & 37 & 35 & 35 & 36 \\
\hline 39702 & Hexachlorobutadiene & 62 & 80 & 76 & 71 & 65 & 73 \\
\hline
\end{tabular}


Table 22. Percent recovery for matrix spikes of volatile organic compounds in water sampled from monitoring wells in Salt Lake Valley, Utah, 1999— Continued

\begin{tabular}{|c|c|c|c|c|c|c|c|}
\hline \multirow[b]{2}{*}{$\begin{array}{l}\text { Parameter } \\
\text { code }\end{array}$} & \multirow[b]{2}{*}{ Compound } & \multicolumn{6}{|c|}{ Recovery (percent) } \\
\hline & & $\begin{array}{c}\text { Matrix spike } \\
09 / 09 / 99\end{array}$ & $\begin{array}{c}\text { Matrix-spike } \\
\text { replicate } \\
09 / 09 / 99\end{array}$ & $\begin{array}{c}\text { Matrix spike } \\
10 / 04 / 99\end{array}$ & $\begin{array}{c}\text { Matrix-spike } \\
\text { replicate } \\
10 / 04 / 99\end{array}$ & $\begin{array}{c}\text { Matrix spike } \\
10 / 19 / 99\end{array}$ & $\begin{array}{c}\text { Matrix-spike } \\
\text { replicate } \\
10 / 19 / 99\end{array}$ \\
\hline 34396 & Hexachloroethane & 76 & 94 & 72 & 73 & 87 & 72 \\
\hline 77103 & 2-Hexanone & 97 & 108 & 95 & 102 & 107 & 93 \\
\hline 77223 & Isopropylbenzene & 81 & 85 & 52 & 86 & 80 & 57 \\
\hline 77356 & 4-Isopropyl-1-methylbenzene & 33 & 38 & 33 & 33 & 32 & 33 \\
\hline 49991 & Methyl acrylate & 101 & 105 & 89 & 104 & 100 & 88 \\
\hline 81593 & Methyl acrylonitrile & 102 & 116 & 98 & 105 & 109 & 100 \\
\hline 77424 & Methyl iodide & 91 & 125 & 80 & 72 & 99 & 78 \\
\hline 81597 & Methyl methacrylate & 100 & 125 & 100 & 102 & 122 & 103 \\
\hline 78133 & 4-Methyl-2-pentanone & 102 & 107 & 96 & 104 & 99 & 103 \\
\hline 78032 & Methyl tert-butyl ether & 92 & 112 & 79 & 90 & 102 & 86 \\
\hline 50005 & Methyl tert-pentyl ether & 100 & 114 & 84 & 92 & 102 & 89 \\
\hline 34696 & Naphthalene & 95 & 85 & 81 & 88 & 77 & 81 \\
\hline 77224 & n-Propylbenzene & 82 & 79 & 68 & 82 & 70 & 67 \\
\hline 77128 & Styrene & 75 & 83 & 53 & 84 & 81 & 56 \\
\hline 77562 & 1,1,1,2-Tetrachloroethane & 84 & 93 & 84 & 70 & 80 & 81 \\
\hline 34516 & 1,1,2,2-Tetrachloroethane & 94 & 96 & 94 & 100 & 96 & 87 \\
\hline 34475 & Tetrachloroethylene & 96 & 105 & 90 & 87 & 83 & 92 \\
\hline 32102 & Tetrachloromethane & 111 & 107 & 88 & 91 & 90 & 91 \\
\hline 81607 & Tetrahydrofuran & 94 & 105 & 99 & 104 & 107 & 98 \\
\hline 49999 & 1,2,3,4-Tetramethylbenzene & 118 & 138 & 159 & 102 & 116 & 156 \\
\hline 50000 & $1,2,3,5$-Tetramethylbenzene & 96 & 106 & 121 & 80 & 86 & 117 \\
\hline 34010 & Toluene & 89 & 99 & 78 & 86 & 84 & 71 \\
\hline 77613 & 1,2,3-Trichlorobenzene & 100 & 90 & 84 & 80 & 77 & 82 \\
\hline 34551 & 1,2,4-Trichlorobenzene & 96 & 83 & 76 & 74 & 71 & 74 \\
\hline 34506 & 1,1,1-Trichloroethane & 109 & 101 & 85 & 94 & 88 & 86 \\
\hline 34511 & 1,1,2-Trichloroethane & 105 & 104 & 100 & 98 & 98 & 96 \\
\hline 39180 & Trichloroethylene & 104 & 98 & 76 & 85 & 84 & 85 \\
\hline 34488 & Trichlorofluoromethane & 101 & 110 & 96 & 94 & 87 & 96 \\
\hline 77443 & 1,2,3-Trichloropropane & 80 & 83 & 79 & 78 & 79 & 74 \\
\hline 77652 & 1,1,2-Trichlorotrifluoroethane & 105 & 105 & 88 & 86 & 85 & 92 \\
\hline 77221 & 1,2,3-Trimethylbenzene & 110 & 115 & 99 & 91 & 93 & 97 \\
\hline 77226 & 1,3,5-Trimethylbenzene & 95 & 88 & 75 & 87 & 72 & 73 \\
\hline 77222 & 1,2,4-Trimethylbenzene & 105 & 95 & 87 & 89 & 77 & 109 \\
\hline 39175 & Vinyl chloride & 115 & 120 & 71 & 87 & 74 & 78 \\
\hline 85795 & $\mathrm{~m}$ - and p-Xylene & 86 & 92 & 61 & 95 & 86 & 65 \\
\hline 77135 & o-Xylene & 79 & 90 & 56 & 87 & 84 & 61 \\
\hline
\end{tabular}




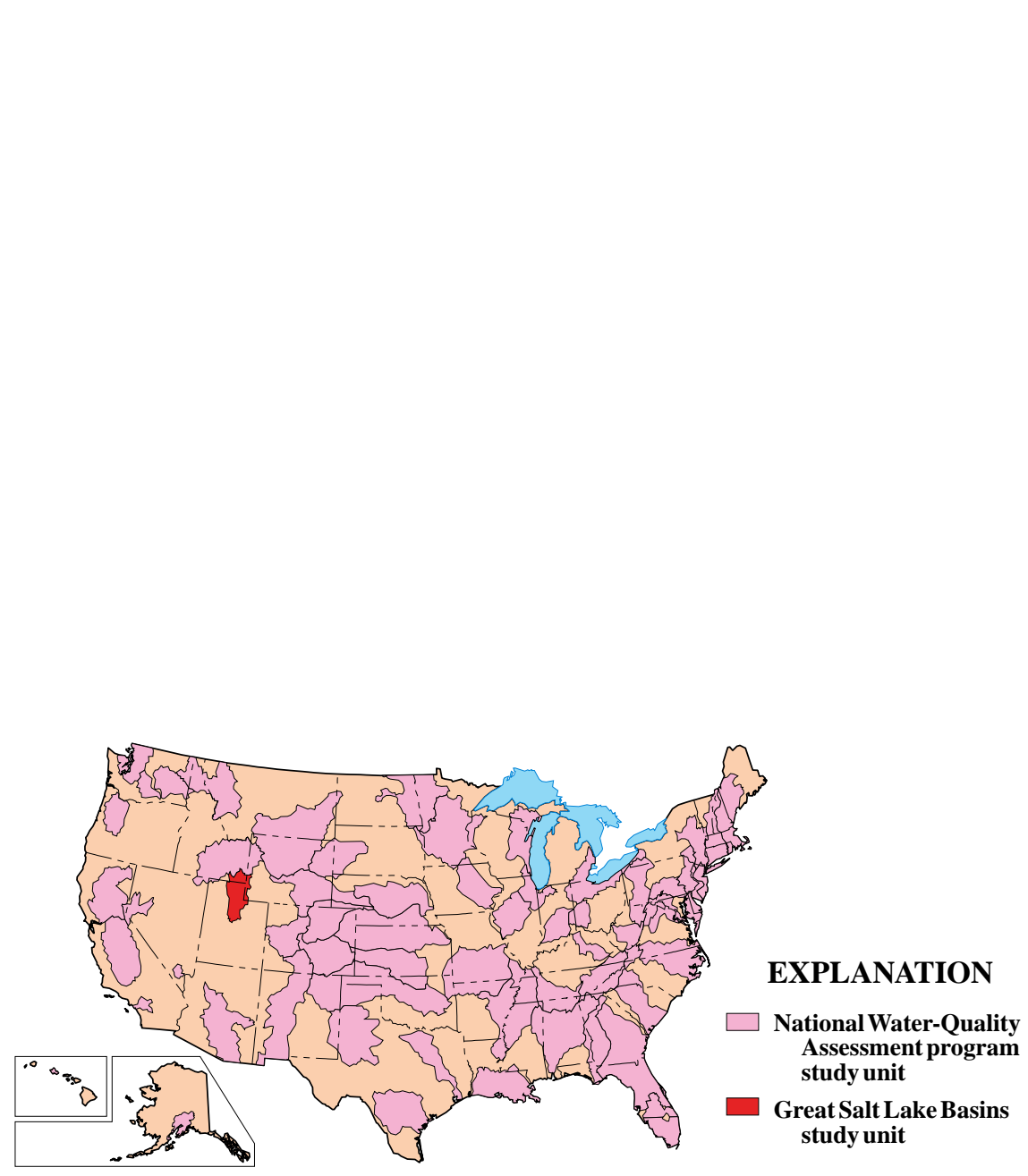

